Old Dominion University

ODU Digital Commons

Summer 2018

\title{
The Impact of Professional Development Grounded in Social Learning on Community College Faculty Efficacy
}

Shanika Shantell Strickland-Davis

Old Dominion University, shantell.stricklanddavis@gmail.com

Follow this and additional works at: https://digitalcommons.odu.edu/stemps_etds

Part of the Higher Education Commons, and the Teacher Education and Professional Development Commons

\section{Recommended Citation}

Strickland-Davis, Shanika S.. "The Impact of Professional Development Grounded in Social Learning on Community College Faculty Efficacy" (2018). Doctor of Philosophy (PhD), Dissertation, STEM Education \& Professional Studies, Old Dominion University, DOI: 10.25777/1kb9-1742

https://digitalcommons.odu.edu/stemps_etds/38

This Dissertation is brought to you for free and open access by the STEM Education \& Professional Studies at ODU Digital Commons. It has been accepted for inclusion in STEMPS Theses \& Dissertations by an authorized administrator of ODU Digital Commons. For more information, please contact digitalcommons@odu.edu. 


\section{THE IMPACT OF PROFESSIONAL DEVELOPMENT GROUNDED IN}

\section{SOCIAL LEARNING ON COMMUNITY COLLEGE FACULTY EFFICACY}

Shanika Shantell Strickland-Davis

B.A. May 2003, University of North Carolina at Charlotte

M.A. December 2011, Appalachian State University

A Dissertation Submitted to the Faculty of

Old Dominion University in Partial Fulfillment of the

Requirements for the Degree of

DOCTOR OF PHILOSOPHY IN EDUCATION

OCCUPATIONAL AND TECHNICAL STUDIES

OLD DOMINION UNIVERSITY

May 2018

Approved by:

Dr. Michael Kosloski (Director)

Dr. Philip A. Reed (Member)

Dr. Mitchell Williams (Member) 


\begin{abstract}
THE IMPACT OF PROFESSIONAL DEVELOPMENT GROUNDED IN SOCIAL LEARNING ON COMMUNITY COLLEGE FACULTY EFFICACY
\end{abstract}

\author{
Shanika Shantell Strickland-Davis \\ Old Dominion University, 2018 \\ Director: Dr. Michael Kosloski
}

Community college faculty have experienced a shift in focus from access to access and student success. Given this shift in responsibility for student learning, community college faculty should be sufficiently prepared to teach a diverse student body and subsequently uphold beliefs regarding their ability to bring about desired outcomes of student engagement and learning. Given preparedness is a measure of self-efficacy, professional development for community college faculty is a critical investment in the support and development of teacher efficacy and faculty skill.

Social learning theory specifically speaks to a means of increasing self-efficacy. As a professional development practice, social learning allows for participants to share problems, ideas, viewpoints, and collaboration towards solutions. Faculty development grounded in social learning theory may serve as a viable option for community college faculty to learn best practices in teaching and learning via social influence and social reinforcement. Therefore, the purpose of this study was to determine the effect, if any, of professional development modeled upon social learning theory on community college teacher efficacy. Administrators and faculty developers may find the results of this study useful as they make decisions about program design and resource allocation. 
A pre-experimental, one-group pre- and post-test research design using the Teacher's Sense of Efficacy Scale was used to measure the effectiveness of a faculty development treatment on teacher efficacy beliefs in the constructs of classroom management, student engagement, and instructional strategies. This method enabled a comparison of efficacy levels prior to and after participation in faculty professional development as a means to determine any potential influence.

Data were analyzed by employing dependent and independent sample $t$-tests to determine differences in teacher efficacy mean scores over time. Findings indicated no significant differences in pre- and post-test scores for overall teacher efficacy and efficacy in the constructs of classroom management, student engagement, and instructional strategies. However, there was a significant difference in overall teacher efficacy scores after participating in the faculty development treatment between new and experienced faculty. From these findings, three themes were drawn that provide specific recommendations for community college faculty development program design. 
Copyright, 2018, by Shanika Shantell Strickland-Davis, All Rights Reserved. 


\section{DEDICATION}

This dissertation is dedicated to my best friend, my greatest supporter, my strongest motivation, and my deepest love, Deron Davis, Sr. Your believing in me with endless encouragement is what keeps me going every day. To Mom, Dad, and Jeffery for always inspiring me to follow my dreams, I love you. Although no longer with us, sweet Deja, you are forever in my heart. 


\section{ACKNOWLEDGMENTS}

There are many who have contributed in various ways to the successful completion of this dissertation. Without this village of support around me, none of this would have been possible. First, I would like to express my deepest appreciation and gratitude to my committee chair, Dr. Michael Kosloski. I appreciate the many hours you spent reviewing and editing my work while providing me the opportunity to trust myself and "trust the process." Your guidance, patience, and persistence from start to finish was critical in this accomplishment; valued feedback I will learn from for many years to come. Thank you Dr. K.

To my dedicated committee members, Dr. Philip Reed and Dr. Mitchell Williams. Thank you for your expertise, generosity in time, and impeccable support throughout this entire process. I was extremely fortunate to have you on my committee, and am humbled at the opportunity I had to learn from your wisdom and experiences.

To my amazing and supportive colleagues. You have each played an important role in this research agenda. Thank you for listening, reading, providing feedback, consulting, and most importantly, taking a personal interest in my success. Words cannot express my appreciation for you and all that you do.

Finally, I would like to acknowledge the efforts and determination of community college faculty in their passion for student success. Thank you for striving to be the best faculty you can be for your students; the impact you make every day is invaluable. 


\section{TABLE OF CONTENTS}

Page

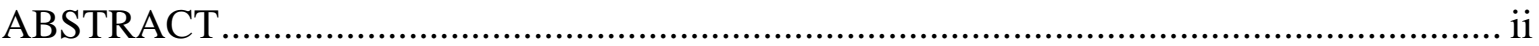

DEDICATION

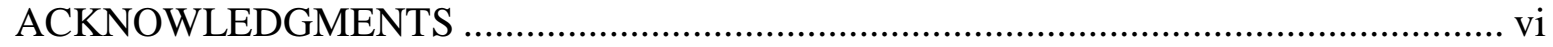

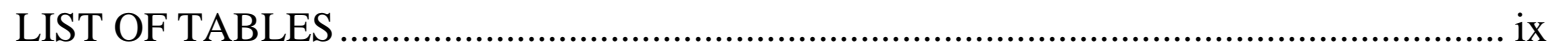

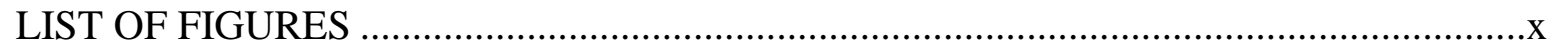

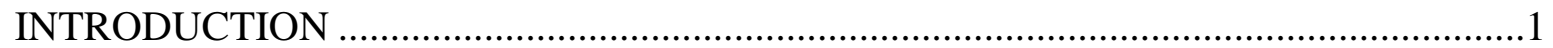

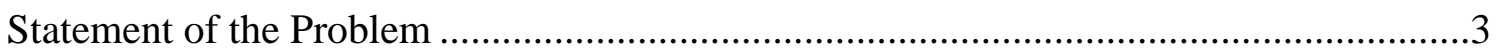

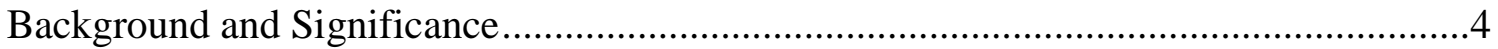

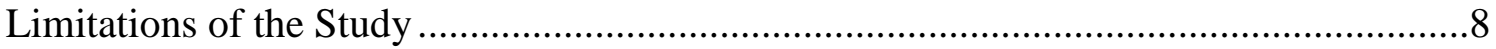

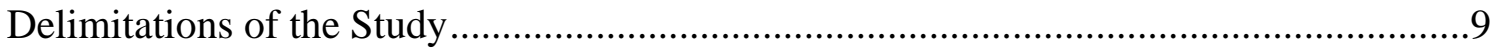

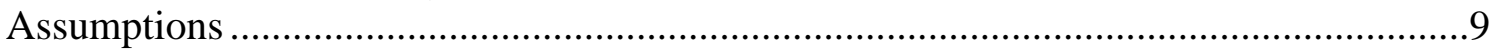

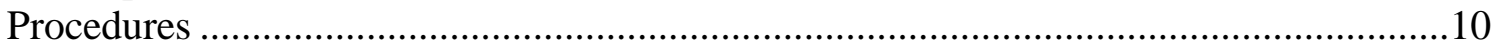

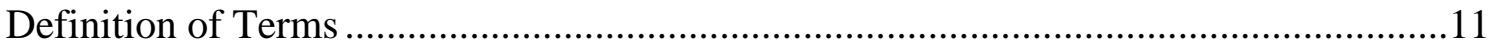

Summary and Overview of Chapters .......................................................................13

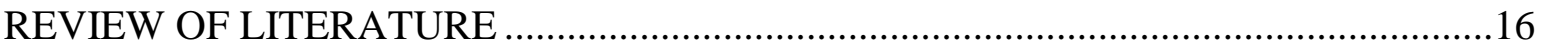

Historical Background .........................................................................................17

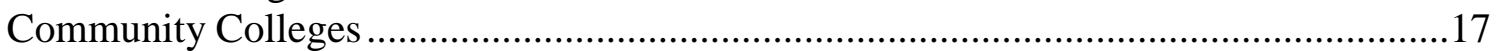

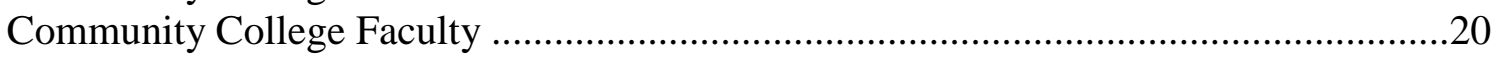

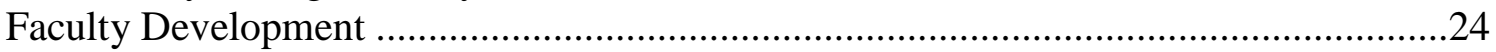

Faculty Development in Community Colleges ...........................................................26

Faculty Development and Teacher Efficacy ................................................................30

Social Learning for Community College Faculty Development .........................................33

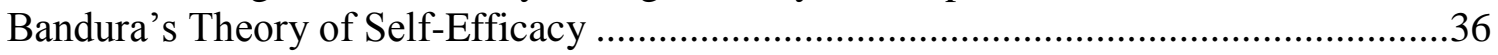

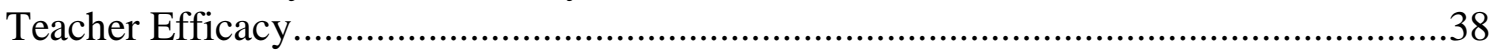

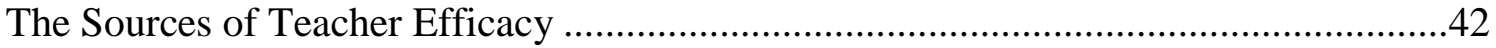

Teacher Efficacy for New Faculty ............................................................................

Application of Bandura's Social Learning Theory ......................................................46

Specific Areas of Teacher Efficacy .......................................................................48

Classroom Management .......................................................................................

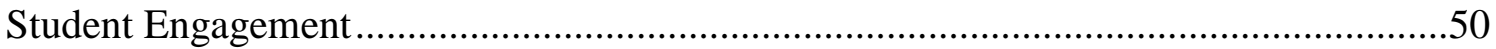

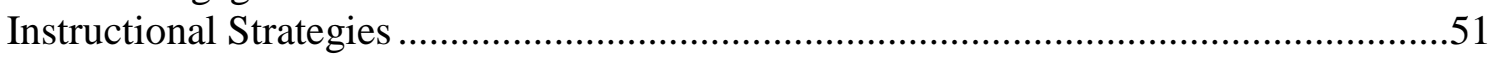




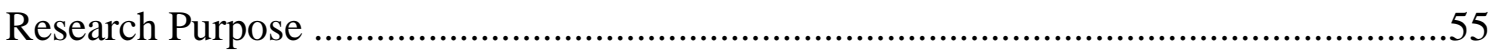

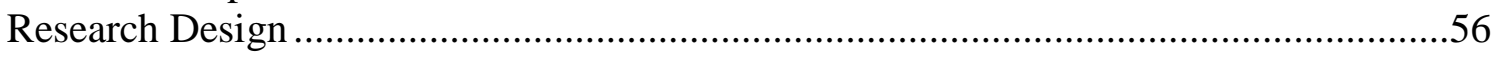

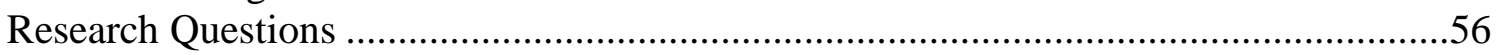

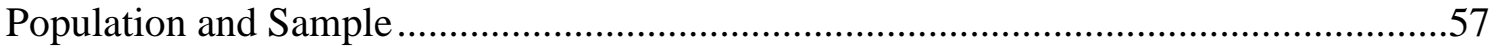

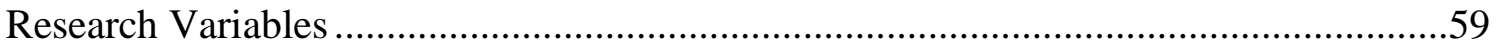

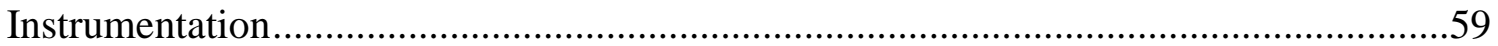

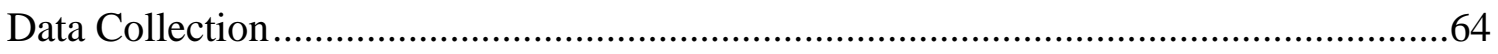

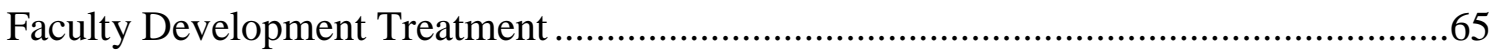

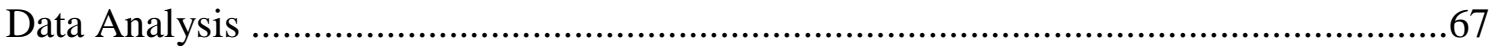

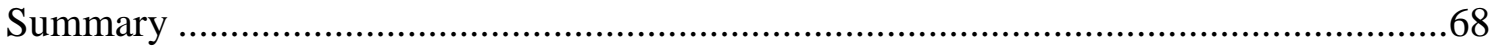

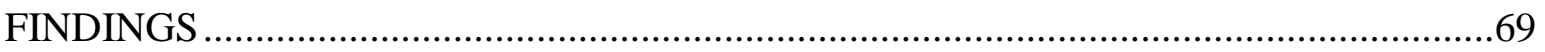

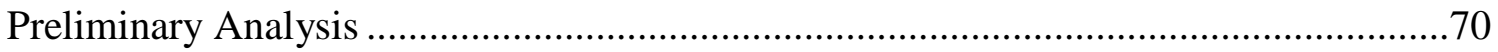

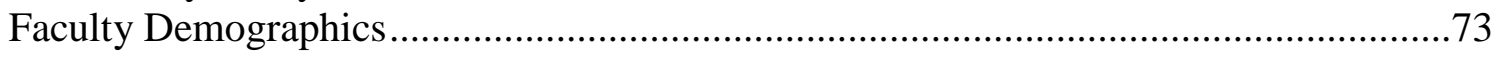

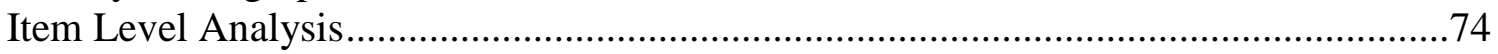

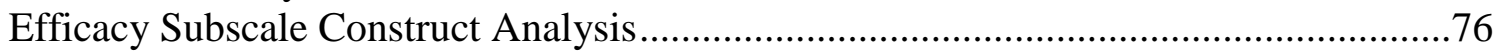

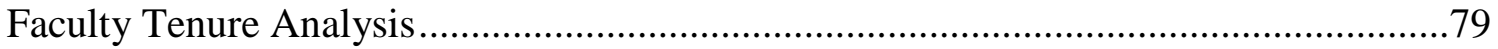

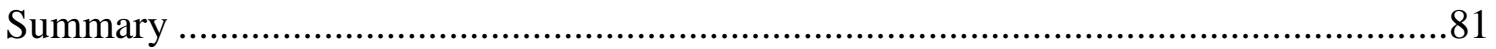

CONCLUSIONS AND RECOMMENDATIONS ..................................................83

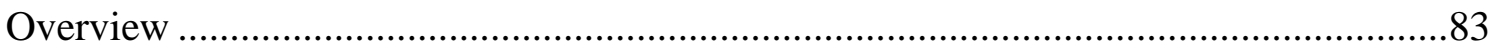

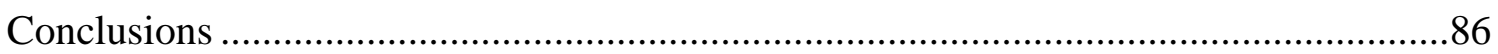

Recommendations for Future Research ............................................................. 96

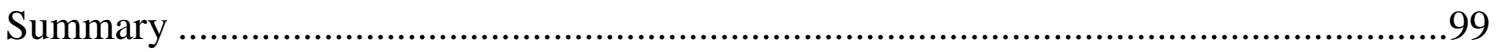

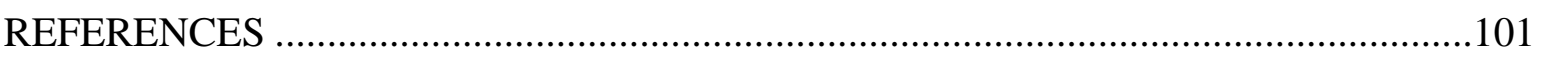

APPENDIX A: Teachers' Sense of Efficacy Scale (TSES) Survey Questions..................121

APPENDIX B: Permission to use the Teachers' Sense of Efficacy Scale ........................122

APPENDIX C: Demographics and Personal Characteristics Questionnaire......................123

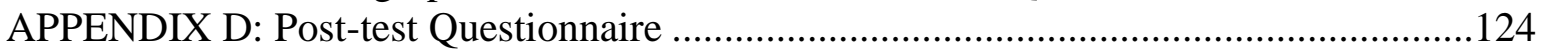

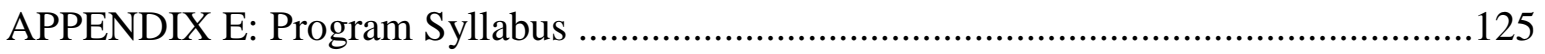

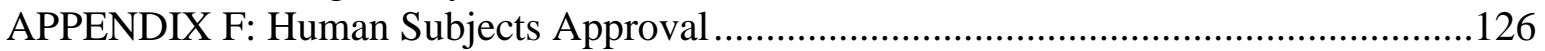

APPENDIX G: Sampling of Qualitative Participant Feedback.....................................127

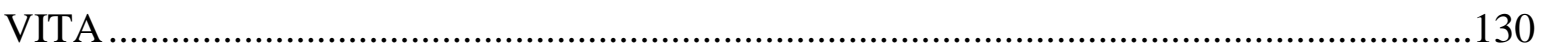




\section{LIST OF TABLES}

Table Page

1. Comparison of Old and New paradigms of Community College Teaching .23

2. Relationship between Research Questions, Variables, and Survey Questions

3. Reliabilities on the Teachers' Sense of Efficacy Scale (2001), short form ..... 62

4. Validity Correlations..... .63

5. Frequencies of Teaching Experience, Education, and Field Experience. .73

6. Descriptive Statistics by Survey Item .74

7. Paired Samples $t$-test Results on Individual Survey Items ..... .75

8. Descriptive Statistics by Efficacy Subscale Construct .76

9. Paired Samples $t$-test Results on Efficacy Subscale Construct.........................................78

10. Descriptive Statistics by Faculty Tenure .79

11. Independent Samples $t$-test on New and Experienced Faculty for Overall Efficacy .80

12. Average Overall Efficacy Pre-test Scores .89 


\section{LIST OF FIGURES}

Figure

Page

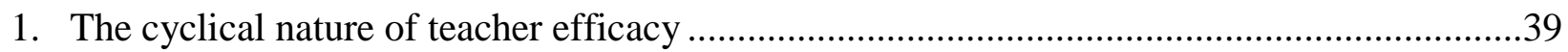

2. Normal Q-Q plots of the calculated pre- and post-test overall teacher efficacy scores...........70

3. Normal Q-Q plots of the calculated pre- and post-test classroom management teacher efficacy scores..

4. Normal Q-Q plots of the calculated pre- and post-test student engagement teacher efficacy scores

5. Normal Q-Q plots of the calculated pre- and post-test instructional strategies teacher efficacy scores. 


\section{CHAPTER 1}

\section{INTRODUCTION}

Institutions of higher learning, particularly community colleges, are expected to prepare students for the workforce. Consequently, there is an expanding performance expectation of community college faculty to serve a variety of students while being both accountable and transparent (Swanger, 2016). Colleges are constantly challenged with increasing enrollment, retention, and completion rates while maintaining quality educational programs geared at preparing students for a life of achievement and success. Leaders of colleges are also being pressured to think differently about how they lead; "clearly defining the outcomes of an institution - especially related to student learning - and how institutions then prove that they are meeting those outcomes and ultimately, students' needs" (Swanger, 2016, p. 4). Furthermore, philanthropic organizations have posed additional initiatives for measuring and improving student progress and success (Cohen, Brawer, \& Kisler, 2014).

Professional development for faculty provides support and guidance regarding bestpractices in classroom management, student engagement, and instructional strategies, but a key consideration is the extent to which such programs effectively influence faculty perceptions of their ability to meet such responsibilities. "Faculty professional development has long been understood as central to improving teacher satisfaction, classroom instruction, and student achievement" (Gyurko, MacCormack, Bless, \& Jodl, 2016, p. 7). Studies indicate that faculty development programs can increase self-efficacy (Rodgers, Christie, \& Wideman, 2013; Nugent, Bradshaw, \& Kito, 1999; Rowbotham, 2015; Singh, De Grave, Ganjiwale, \& Supe, 2013; Zonoubi, Rasekh, \& Tavakoli, 2017), and teachers with high self-efficacy expect to promote student learning (Heslin \& Klehe, 2006; Morris \& Usher, 2011). Institutions of higher learning 
need to invest appropriate resources towards effective faculty development programs (Sprouse, Ebbers, \& King, 2008; Younger, 2011), but more importantly, such support must illustrate new models that promote authentic learning and development opportunities (Chung Wei, DarlingHammond, Andree, Richardson, \& Orphanos, 2009; Desimone, 2009; Desimone, Porter, Garret, Yoon, \& Birman, 2002; Garet, Porter, Desimone, Birman, Yoon, 2001; Penuel, Fishman, Yamaguchi, \& Galagher, 2007; Wayne, Yoon, Cronen, \& Garet, 2008).

A common goal of faculty development in the community college is "assisting faculty in the development of quality curricula using current and expanding teaching technologies" (Quick \& Davies, 1999, p. 641), while providing opportunities for them to acquire the knowledge, skills, and efficacy required for student success. Specific to this study is an understanding that a teacher's sense of self-efficacy, pertaining to classroom management, student engagement, and instructional strategies, is crucial for subsequent variables of student success; learning outcome attainment, student retention, and completion. Different models of faculty development attempt to increase faculty ease and skill, but there is limited understanding of how specific models may or may not be effective for community college faculty.

There has been limited research on the effects of professional development intended to increase teacher efficacy (Karimi, 2011). Faculty development modeled upon social learning theory, which specifically speaks to a means of increasing teacher efficacy, may be a viable option for increasing community college faculty skill and development. Social learning theory, proposed by Albert Bandura, suggests that new behaviors can be acquired through the observation of others via the concept of modeling; that people can regulate their behavior in response to something they witness as an observation, or engage in as a first-hand experience (Bandura, 1977). Aspects of social learning theory are already present in many faculty 
development practices, such as learning communities, which engage teachers socially through regular opportunities to share problems, ideas, viewpoints, and collaboration towards solutions (Clement, 2012; Guskey, 1995; Hunzickler, 2010). However, few studies are available that speak to the effectiveness of how such a model, embedded and characterizing faculty development, is effective in increasing faculty efficacy (Garet et al., 2001). Additionally, Karimi (2011) maintains, "Research intended to reveal the effects of interventions which have the potential to enhance teachers' beliefs about their ability is called for" (p. 59).

This study intends to add to the literature and provide data-driven recommendations regarding community college faculty development. Administrators and faculty developers may find the results of this study useful as they make decisions about program design and resource allocation. The effectiveness and promise of community college faculty development grounded in social learning theory was explored by examining teacher efficacy beliefs associated with teaching in the areas of classroom management, student engagement, and instruction.

\section{Statement of the Problem}

Community college faculty members represent a diverse group, with varying levels of educational attainment and proficiencies in classroom management, student engagement, and instructional strategies (Finley \& Kinslow, 2016). As a result, the purpose of this study was to determine the effect, if any, of professional development modeled upon social learning theory on community college teacher efficacy.

\section{Research Questions}

The following research questions framed this study:

$\mathrm{RQ}_{1}$ : What effect, if any, does a faculty development program explicitly modeled upon social learning theory have on community college overall teacher efficacy? 
$\mathrm{RQ}_{2}$ : What effect, if any, does a faculty development program explicitly modeled upon social learning theory have on community college teacher efficacy specific to managing a classroom?

$\mathrm{RQ}_{3}$ : What effect, if any, does a faculty development program modeled upon social learning theory have on community college teacher efficacy specific to cultivating student engagement?

$\mathrm{RQ}_{4}$ : What effect, if any, does a faculty development program modeled upon social learning theory have on community college teacher efficacy specific to implementing instructional strategies?

RQ5: What effect, if any, does years of teaching experience have on community college overall teacher efficacy after participating in a faculty development program modeled upon social learning theory?

\section{Background and Significance}

Community colleges hold a unique purpose in higher education, serving as an avenue for individual social mobility (Cohen et al., 2014), educational problem solving (Trainor, 2015), innovation (Brint \& Karabel, 1989), diversity and affordability (Baker, Hope, \& Karandjeff, 2009; Crawford \& Jervis, 2011), and providing a pathway for career readiness and entry into four-year colleges and universities. Historically, open-access admission, the hallmark of community colleges, provides disadvantaged groups access to education and workforce training. However, in recent years community colleges, and consequently community college faculty, have experienced a shift in focus and accountability from simply access to access and student success (Baldwin, 2014; Barr \& Tagg, 1995; Morest, 2012; Nunley, Bers, \& Manning, 2011; Toner, 2016). 
By 'success' we mean the achievement of overall student educational objectives such as earning a degree, persisting in school, and learning the 'right' things - the skills and knowledge that will help students to achieve their goals in work and life. (Barr \& Tagg, 1995, p. 14)

Faculty are now being held accountable for effective course design, practices for student retention, and professional duties with respect to academic administration and college governance (Baker, Hope, \& Karandjeff, 2009; Smith, 2013; Van Ast, 1999). These additional responsibilities do not naturally align with the historical and current preparedness of community college faculty. Faculty members may possess the subject matter expertise in their discipline, trade, or industry, but often times do not have the teaching and learning expertise to maximize learning efficiency (Chung Wei et al., 2009; Malnarich, 2008; Wyles, 1998).

Faculty members prepared by traditional graduate programs are frequently unprepared for the pedagogical challenges of the open door institution (Cohen and Brawer, 1996). The desired academic credential, a master's degree with a minimum of 18 graduate hours in the discipline (Southern Association of Colleges and Schools, 2003), may support expertise in the subject area, but typically does not provide what is needed to fully understand the art of teaching and learning (a continuous journey to find the right combination of pedagogy, instructional methodologies, and more recently, computer-based instruction to help students learn). The master's degree is seen as broader than a doctorate, providing the depth needed to teach associate degree students (Townsend \& Twombly, 2007). Moreover, vocational and technical degree programs may require only a baccalaureate or associate degree for an instructor, with hiring preference given for industry experience, often referred to as "real world experience" (Finley \& Kinslow, 2016, p. 5) over an academic credential (Twombly \& Townsend, 2008). 
Regardless of educational attainment or industry experience, community college faculty members are responsible for educating students with a broad range of academic abilities and diverse backgrounds, including first-generation, international, and older adults returning to school (Morest, 2013). "Community college students tend to be more underprepared, with some students specifically attending a community college to take developmental courses, since these remedial-level courses may no longer be offered at the state institutions” (Finley \& Kinslow, 2016, p. 4). Although faculty may have expertise or experience within their specific subject area or field, many do not have teaching experience, teaching credentials, or professional development related to the art of teaching and learning (Illian, 2008) to appropriately design and facilitate instruction that addresses this diverse student body. Faculty start the first day of the semester facing some of the most challenging students in higher education, with little to no training or experience in how to teach (Hamblin, 2016). Furthermore, teaching is the primary responsibility of community college faculty (Cohen et al., 2014; Finley \& Kinslow, 2016) comprising $89 \%$ of their time, compared with $63 \%$ of time for faculty in four-year institutions (Provasnik \& Planty, 2008). Finley and Kinslow (2016) describe a course load for faculty at most community colleges as five three-credit courses per term, with faculty often taking on additional overload courses to meet the needs of their departments. In addition to teaching, community college faculty have advising responsibilities, academic preparation for their classes, college service requirements, administrative duties, and committee work to undertake, but are also being held responsible for student success, retention, and completion.

With limited time for formal professional development, community college faculty members tend to engage in informal development for teaching and learning. They commonly emulate the teaching styles from their own experiences which may be antiquated, inappropriate, 
or ineffective (Baran, Correia, \& Thompson, 2011; Covill, 2011; Garet et al., 2001; Gyurko, MacCormack, Bless, \& Jodl, 2016). "Many college faculty remain unaware of their students' learning needs; thus, they use outdated, ineffective teaching strategies that adversely affect students' ability to achieve the learning outcomes" (Elliott \& Oliver, 2016, p. 85).

Preparedness is a measure of self-efficacy (Bandura, 1977). Knowing that preparedness is linked to self-efficacy means that community college faculty should be sufficiently prepared to teach the diverse population of community college students. Teacher efficacy, defined here as "the situation-specific belief that a teacher holds regarding his or her abilities and skills to positively impact student motivation and achievement" (Gavora, 2010; Gibson \& Dembo, 1984; Tschannen-Moran \& Woolfolk Hoy, 2001), centers around the beliefs faculty have in their abilities to affect student learning in their role as educators. Research on teacher efficacy suggests that teaching behaviors such as persistence at a task, risk-taking and the use of innovations are related to high levels of self-efficacy (Ashton \& Webb, 1986; Guskey, 1988).

A study conducted by Fishback, Leslie, Peck, and Dietz (2015) concluded that faculty members' views of self-efficacy are linked to their beliefs about how a good teacher behaves (Rodgers, Christie, \& Wideman, 2013), and that the attitudes faculty hold about good teaching practices impact the choices they make in the classroom. "Teacher efficacy has proved to be powerfully related to many meaningful educational outcomes such as teachers' persistence, enthusiasm, commitment, and instructional behavior, as well as student outcomes such as achievement, motivation, and self-efficacy beliefs" (Tschannen-Moran \& Woolfolk Hoy, 2001, p. 783). Considering these views, addressing teacher efficacy in community college faculty may then become an important consideration in the development of a strategy community colleges can use in programs aimed at developing faculty (Tyndall, 2017). 


\section{Limitations of the Study}

The limitations of this study include:

1. The sample was limited to a large urban community college in the southeastern United States. Findings from this study may not be generalizable to all community colleges.

2. The use of self-reported surveys. These instruments are susceptible to answers colored with social desirability (Kahn, Fleva \& Qazi, 2015), in which people may misreport depending on the degree of question sensitivity or what they may perceive as a threat (Northrup, 1996).

3. The use of a pre-experimental, one-group, pre-test-post-test design. According to Marsden and Torgerson (2012),

Any evaluative approach that uses this design provides weak information about the counterfactual inference and may be subject to a number of confounding variables, such as history ... and the statistical phenomenon known as the regression to the mean (RTM) effect. (p. 584)

4. The use of pre-existing data. Quality assurance of the data collection protocol was beyond any control of the researcher.

5. Some participants will likely be more confident than others regardless of the faculty development treatment.

6. No defined tools or processes to evaluate the quality or effectiveness of the faculty development treatment. The case study method is cited in literature (Allen, 1988) as the most effective method for evaluating faculty development programs. This evaluative approach is effective "because it examines the program as a whole, including its rationale and evolution, activities, accomplishments, and difficulties" (Wergin, 1977, p. 70). 


\section{Delimitations of the Study}

The delimitations of this study include:

1. Part-time (adjunct) faculty survey data were excluded from this study. Part-time faculty at the case institution are not required to participate in professional development beyond required training of all employees and training specific to academic administration. Additionally, part-time faculty are not compensated to participate in supplementary opportunities for professional development. Compensating part-time faculty to participate in the faculty development treatment modeled upon social learning was not feasible at the time of the study.

2. The Teachers' Sense of Efficacy Scale (TSES) can be used to evaluate teacher efficacy in four key areas: Total efficacy construct, efficacy in classroom management, efficacy in instructional strategies, and efficacy in student engagement (Tschannen-Moran \& Woolfolk Hoy, 2001). There are two forms of the TSES: the short form (12 items) and long form (24 items). To reduce the length of the long form, four items assessing teacher efficacy for classroom management ( $\alpha=.85$ ), four items assessing teacher efficacy for student engagement $(\alpha=.78)$, and four items assessing teacher efficacy for instructional strategies $(\alpha=.74)$ were used to create the short form. Although there is a recommendation from the authors (Tschannen-Moran \& Woolfolk Hoy, 2001) that the full scale (long form) be used with pre-service (new) teachers, the case institution's Office of Professional Development made the decision to use the short form for all participants. Use of the short form TSES served the purpose of increasing participant response rates and ensuring consistent measurement across all faculty surveyed.

\section{Assumptions}


This research design assumed that any changes in teacher efficacy from the survey instrument responses were the result of the faculty development treatment employed (Research Connections, 2016). It was also assumed that participants in the study would put forth the effort to fully engage in the faculty development program meant to develop and improve skills associated with teaching tasks related to classroom management, student engagement, and instructional strategies.

\section{Procedures}

This study utilized a quantitative method to analyze existing survey data of community college faculty members at a single institution. The data provided a means to explore the effectiveness of a faculty development model based upon social learning theory. The participants of this study were full-time faculty members at a large urban community college in southeastern United States representing both general education and applied science areas.

A pre-experimental, one-group, pre-test-post-test research design with pre-existing data was used to measure the effectiveness of a faculty development program on teacher efficacy beliefs. A survey administered to the faculty participants before and after the faculty development program enabled a comparison of efficacy levels prior to and after implementation as a means to determine any potential influence.

The Teachers' Sense of Efficacy Scale (TSES; Tschannen-Moran \& Woolfolk Hoy, 2001), a documented reliable and valid instrument (Fives \& Buehl, 2010; Statistics Solutions, 2017), was administered to participating faculty members to examine teacher efficacy. This scale, developed by Tschannen-Moran and Woolfolk Hoy, came from concern for a lack of sufficient measures of efficacy in previous studies on teachers' self-efficacy (Tschannen-Moran \& Woolfolk Hoy, 2001). Based on the scale advocated by Bandura in 1997, the TSES assesses 
overall (or total) teacher efficacy and additionally, factor analysis supports three distinct factors of efficacy: student engagement, instructional practices, and classroom management (Parker, 2014). Using data provided by the TSES, the research questions in this study were addressed using the overall and subscale efficacy scores. Findings from the scale, overall efficacy construct, and subscale efficacy constructs (classroom management, student engagement, and instructional strategies), are presented and interpreted in the data analysis and results section of Chapter IV.

The faculty development treatment modeled upon social learning theory was designed by the Office of Professional Development at the case institution. There are four components of social learning theory: attentional processes, where various influences increase or decrease attention; retention processes, or recognizing symbolic information; motor reproduction, or converting/reproducing information into action; and motivational processes, where motives provide reason to emulate. Each of these four components were emphasized in treatment activities along with opportunities for faculty participants to build upon sources of teacher efficacy: mastery experiences, social modeling, social persuasion, and cognitive states. Each component and efficacy source is further defined in Chapter II.

\section{Definition of Terms}

The following terms and concepts are integral aspects of this study, and as such, are explicitly articulated and defined as follows:

Faculty Development Program: An explicitly designed program inclusive of "activities designed to assist the faculty member in becoming a better teacher, a more competent professional, or a fully functioning person" (Allen, 1988, p. 89). 
Social Learning Theory: Social learning theory suggests that new behaviors can be acquired through the direct instruction or the observation of others via the concept of modeling; that people can regulate their behavior in response to something they witness as an observation, or engage in as a first-hand experience (Bandura, 1977).

Social Cognitive Theory: Social cognitive theory, developed from social learning theory in 1986 by Albert Bandura, posits that learning occurs in a social context with a dynamic and reciprocal interaction of the person, environment, and behavior. The unique feature of social cognitive theory is the emphasis on social influence and social reinforcement (Lamorte, 2016).

Self-Efficacy Beliefs: Self-efficacy beliefs determine how people feel, think, motivate themselves, and behave (Bandura, 1977).

Teacher Efficacy: “A judgment of his or her capabilities to bring about desired outcomes of student engagement and learning, even among those students who may be difficult or unmotivated" (Tschannen-Moran and Woolfolk Hoy, 2001, p. 784). Used interchangeably with Teachers' Sense of Efficacy and teacher self-efficacy.

Classroom Management: Classroom management refers to the design and implementation of efficient classroom routines, policies, and procedures for classroom participation, activities, and interactions (Henderson, 2016).

Student Engagement: Student engagement is a "student's cognitive investment in, active participation in, and emotional commitment to their learning". It may also refer to a student's “involvement with activities and conditions likely to generate high-quality learning," (Zepke \& Leach, 2010, p. 168). 
Instructional Strategies: Instructional strategies are the techniques or methods that a teacher can adopt to meet various learning objectives. They focus on the educational content as well as the method and environment of the teaching process (Richa, 2014).

TSES: Teachers' Sense of Efficacy Scale, developed by Tschannen-Moran and Woolfolk Hoy (2001), came from concern for a lack of sufficient measures of teacher efficacy beliefs. This instrument assesses teachers' efficacy beliefs for completing critical tasks associated with teaching in the areas of classroom management, student engagement, and instructional strategies.

Training: Training refers to the process of imparting specific skills. Training is typically application focused, has a narrow perspective, and is job specific (Human Resources Management, 2012).

\section{Summary and Overview of Chapters}

This study sought to explore the effectiveness of a community college faculty development model based upon social learning theory. Community colleges, and consequently community college faculty, have experienced a shift in focus and accountability from simply access to access and student success (Baldwin, 2014; Barr \& Tagg, 1995; Morest, 2012; Nunley et al., 2011; Toner, 2016). Community college faculty members are not typically prepared with knowledge and skills regarding teaching methodologies and practices attuned to student success, retention, and completion; rather, they are often highly skilled and knowledgeable within their own field or subject matter (Younger, 2011). "Instructional leaders must discover which professional development activities result in behavioral changes in teachers that translate to improved student success (Hamblin, 2015, p. 112). Faculty development plays an important role in community colleges, supporting and providing opportunities for faculty growth and behavioral changes, yet few studies are available pertaining specifically to the community college faculty 
population. Even fewer studies have tested specific models of faculty development at the community college level. Results from this study will help fill this gap and add to the understanding of community college faculty development needs. More importantly, findings may provide possible options for best supporting community college faculty as they attend to the ever-increasing accountability for student success.

In summary, community college faculty are expected to provide and ensure student learning that reflects best practices in establishing classroom management, cultivating student engagement, and implementing instructional strategies. There is a need for faculty development programming that provides support and guidance regarding these expectations. An effective faculty development model should improve skill and knowledge, which in turn will increase teacher efficacy (Rodgers et al., 2013; Rowbotham, 2015; Singh et al., 2013). There are different models that attempt to increase faculty ease and skill, but limited understanding of how specific models may or may not be effective for the community college faculty population.

Chapter I provided an introduction, background, and statement of the problem for this study. Chapter II will provide a historical background on community colleges, community college faculty, and faculty development. Empirical literature on the topics of faculty development, teacher efficacy, and social learning for community college faculty development is reviewed. Finally, Bandura's theory of self-efficacy and the application of social learning theory are discussed as the framework for this study. Chapter III provides an explanation of the methodology, including the research purpose, research design, study population, research variables, instrumentation, data collection methods, faculty development treatment, and the data analysis performed. Findings of the study will be presented in Chapter IV. Lastly, Chapter V 
will include the summary, conclusions, and recommendations for implementing the findings of this study for future research. 


\section{CHAPTER 2}

\section{REVIEW OF LITERATURE}

Faculty development programs provide faculty support and guidance regarding roles, responsibilities, and teaching expectations, but a key consideration is the extent to which such programs effectively influence faculty perceptions of their ability to meet such responsibilities. Considering the environment faced by community college faculty "where individual autonomy is interfaced with organizational interdependence... faculty member efficacy is an important area for exploration" (Shavaran, Rajaeepour, Kazemi, \& Zamani, 2012). Studies indicate faculty with high self-efficacy expect more of themselves and their students (Heslin \& Klehe, 2006; Kahn et al., 2015), and faculty development programs can increase one's perception of self-efficacy (Nugent, Bradshaw, \& Kito, 1999; Rodgers, Christie, \& Wideman, 2013; Rowbatham, 2015; Singh, De Grave, Ganjiwale, \& Supe, 2013; Zonoubi, Rasekh, \& Tavakoli, 2017). Different models of faculty development attempt to increase faculty ease and skill, but there is limited understanding of how specific models may or may not be effective for community college faculty.

The following literature review provides a historical background regarding community colleges, community college faculty, faculty development, and specifically, faculty development in the community college. Extant studies regarding teacher efficacy and social learning theory are examined, and Bandura's theory of self-efficacy and application of social learning as a framework for this study is reviewed. Finally, the concept of teacher efficacy is discussed, specific to the areas of classroom management, student engagement, and instructional strategies. 


\section{Historical Background}

\section{Community Colleges}

Community colleges are an alternative to traditional four-year public and private universities in higher education. Community colleges offer a more advanced curriculum than secondary school, and serve as a local and often lower-cost pathway to the university for adult learners, displaced workers, lifelong learners, workforce learners, developmental learners, and non-traditional learners (Baker, Hope, \& Karandjeff, 2009; Raby \& Valeau, 2014).

Established in every metropolitan area, they [community colleges] were available to all comers, attracting the "new students": minorities, women, people who had done poorly in high school, those who would have otherwise never have considered or been able to afford further education. (Cohen et al., 2014)

Also known as Colleges of Further Education, City Colleges, County Colleges, Polytechnics, Technical Colleges, Junior Colleges, and Technical and Further Education (Cohen \& Brawer, 1996; Cohen et al., 2014; Raby \& Valeau, 2014), these institutions "share a mission that views educational access as necessary for growing the economic and social capital that is needed to help students improve [their] lives" (Raby \& Valeau, 2014, p. 6). Cohen et al. (2014) further define the community college as "any not-for-profit institution regionally accredited to award the associate of arts or the associate of science at its highest degree" (p. 5). However, "as some twoyear schools are beginning to offer bachelor's degrees, it is becoming less clear exactly what a community college is" (Finley \& Kinslow, 2016, p. 2).

Historically, community colleges have served local communities regarding workforce and social needs, such as business and industry training and promoting cultural appreciation. Their role also includes providing a quality open-access education with "various curricular 
functions noted in each state's legislation that usually includes academic transfer preparation, vocational-technical education, continuing education, remedial education, and community service" (Cohen \& Brawer, 1996, p. 21). Community colleges now operate in every state and enroll $41 \%$ of the students who begin college in America (American Association of Community Colleges, 2017). According to Cohen et al. (2014), "community colleges will sustain their enrollment... by 2020 they will enroll eight million students, or nearly 43 percent of all higher education” (p. 441).

Student success, retention, and completion are key areas of focus for community colleges. The Center for Community College Engagement (2012) reminds us,

Never has it been so clear that the futures of individuals, communities, and the nation rest significantly on the ability of community and technical colleges to ensure that far greater numbers of their students succeed in college, attain high-quality certificates and degrees, and transfer to baccalaureate institutions. (p. 1)

Community colleges are continuously being challenged to improve student success and completion, while increasing both access and quality (Boggs, 2012); "they are a cornerstone of [former] President Obama's initiative to achieve the highest level of postsecondary educational attainment in the world by 2020" (American Association of Community Colleges, 2012, p. 5). Playing an essential role in preparing the nation's workforce, community colleges have become institutions of choice for workers upgrading their skills and for displaced workers looking to reenter the workforce. Community colleges must respond quickly to meeting the needs of the community in their close work with industry, government, and other education sectors (Boggs, 2012). "Various efforts to make community colleges more efficient have been undertaken in 
order to increase student learning and, at the same time, maintain cost-effectiveness" (Cohen \& Brawer, 1996, p. 134).

Deemed the most successful innovation in $20^{\text {th }}$ century American higher education (Brint \& Karabel, 1989), community colleges today are extending its diversity with early college high schools and baccalaureate degrees (Cohen et al., 2014). Considering this growth, administrators, faculty, and staff members have all had to adjust (Cohen \& Brawer, 1996; Hainline, Gaines, Feather, Padilla, \& Terry, 2010), especially now that the institutions have further developed the reputation as the innovator in $21^{\text {st }}$ century higher education (Levin, Kater, \& Wagoner, 2006). Hainline et al. (2010) argue,

Just as technologies have greatly influenced how we teach the twenty-first-century class, new knowledge has added to the possibilities for what we can teach, and this combination of new technologies and new knowledge has resulted in almost limitless opportunity for twenty-first-century curricular offerings. (para. 9)

The Partnership for $21^{\text {st }}$ Century Skills (2009) states "To succeed in college, career and life in the 21 st century, students must be supported in mastering both content and skills" (p. 2). This organization argues that standards, typically defined as essential academic content knowledge, should also define skills - such as critical thinking, communication, and information technology - students need to be successful in the $21^{\text {st }}$ century.

Such national standards are reframing the role of community colleges:

...the economy is changing the roles of educational institutions, student populations and faculty roles by demanding the leveraging of resources and the integration of outcomes between the private and public sector. Preparing students to be productive members of today's workforce will mean institutions must walk the tightrope between pre- 
professional subjects and the liberal arts and sciences, ensuring students meet workforce demands and learn the practical application of their knowledge. (Hainline et al., 2010, para. 24)

Lancaster, Stein, MacLean, Van Amburgh, and Persky (2014) explain:

There are increasing numbers of... faculty members who must be prepared to train students in skills such as critical thinking and problem solving; working in teams and collaborating; communicating with others; and finding and analyzing information. Working with students to develop these skills requires a different teaching approach and is a paradigm shift for many faculty members. (p. 1)

\section{Community College Faculty}

Research indicates that forty-three percent of all full- and part-time faculty members [in higher education] work in community colleges (Association for the Study of Higher Education [ASHE], 2007). Yet, most research regarding faculty has been in four-year institutions. ASHE (2007) reports,

Lack of knowledge about community college faculty results in reliance on portraits of community colleges and their faculties derived from a comparison with four-year college faculty, an inappropriate comparison that typically leaves community college faculty found wanting. (p. 2)

Community college faculty serve a unique role in education and provide benefits to an array of constituents (Pusser \& Levin, 2009). "Although it is possible to generalize in only the grossest way when one is describing a quarter-million people, demographically the community college faculty differ from instructors in other types of schools" (Cohen \& Brawer, 1996, p. 76). Secondary teachers "survive in a culture where decision making occurs at the top level and 
trickles to classroom... standards for grade level work ... may occur at the local board of trustees or even the state superintendent of instruction" (Smith, 2013, para. 2). University faculty are expected to conduct research in scholarship and spend less time in class with students (Price \& Cotten, 2006). Community college faculty have a focus somewhere in the middle; where the primary responsibility is to teach (Cohen \& Brawer, 1996; Cohen et al., 2014; Provasnik \& Planty, 2008). "Because community college instructors have never devoted much time to research or academic discipline-based scholarship, they have been free to address nearly their full attention to instructional processes" (Cohen \& Brawer, 1996, p. 161). Conversely, other researchers view community college faculty as a response to the need of external interests. Faculty are public service professionals; "consultants, salespeople, account representatives, troubleshooters - the human connection between the organization and markets" (Levin, Kater, \& Wagoner, 2006, p. 22). Despite these facts, the ASHE (2007) Higher Education Report concludes, "community college faculty are overlooked and undervalued" (p. 1).

Most community college faculty members hold master's degrees or have at least the equivalent experience in the occupations they teach. They are less likely to hold terminal degrees than university professors (Cohen \& Brawer, 1996). Although community college faculty tend to have occupational or discipline-specific expertise, they tend not to have formal training regarding pedagogy, instructional strategies, or assessment (Angelo, 1994; Cohen et al., 2014; Younger, 2011). Community colleges employ approximately 68 percent of their faculty as part-time employees (Ginder, Kelly-Reid, \& Mann, 2017), many of them usually employed elsewhere in full-time professional positions (Leslie \& Gappa, 2002). These faculty (part-time) members teach more than half (53 percent) of all students at two-year institutions (Fain, 2014). 
The community college faculty's mission of teaching and learning reflects an appreciation for and expectation of personal and professional growth. A national survey of 2,678 community college faculty conducted by the Higher Education Research Institute at the University of California found that " $72.7 \%$ experiences joy in their work, $70 \%$ feel good about the direction in which life is headed, and $71.1 \%$ feel that their own work adds meaning to life" (Modern Language Association, 2006, para. 3). This appreciation extends to and is further acknowledged with community college faculty's perception of their role in student success. Finley (2016) informs us

Even with the challenges of students' varying backgrounds, teaching at a community college can be immensely rewarding because of one's ability to help make a genuine difference in the lives of students. Some of our students never thought they would have the chance to pursue higher education, or they came from countries where only the privileged could enter a university. I have received thank-you notes from students who were grateful for the chance to learn. Watching students get excited about learning and encouraging them to continue their education makes teaching worthwhile. (p. 10)

Although many community college faculty are encouraged and expect to make a difference with their students, they are still faced with a new paradigm of teaching (Van Ast, 1999). Table 1 summarizes this shifting paradigm, from teaching and learning through assumptions about the role of faculty in higher education. 
Table 1

Comparison of Old and New Paradigms of Community College Teaching

Old paradigm New paradigm

\begin{tabular}{|c|c|c|}
\hline Knowledge & $\begin{array}{l}\text { Transferred from faculty to } \\
\text { students }\end{array}$ & $\begin{array}{l}\text { Jointly constructed by } \\
\text { students and faculty }\end{array}$ \\
\hline Students & $\begin{array}{l}\text { Passive vessel to be filled by } \\
\text { faculty's knowledge }\end{array}$ & $\begin{array}{l}\text { Active constructor, discoverer, } \\
\text { transformer of own } \\
\text { knowledge }\end{array}$ \\
\hline Faculty purpose & Classify and sort students & $\begin{array}{l}\text { Develop students' } \\
\text { competencies and talents }\end{array}$ \\
\hline Relationships & $\begin{array}{l}\text { Interpersonal relationships } \\
\text { among students and between } \\
\text { faculty and students }\end{array}$ & $\begin{array}{l}\text { Personal transaction among } \\
\text { students and between faculty } \\
\text { and students }\end{array}$ \\
\hline Context & Competitive, individualistic & $\begin{array}{l}\text { Collaborative learning in } \\
\text { classroom and collaborative } \\
\text { teams among faculty }\end{array}$ \\
\hline Assumptions & Any expert can teach & $\begin{array}{l}\text { Teaching is complex and } \\
\text { requires considerable training }\end{array}$ \\
\hline
\end{tabular}

Note. Adapted from "Community college faculty: Making the paradigm shift", by J. Van Ast, (1999), Community College Journal of Research and Practice, 23(6), p. 565.

Regarding this critical shift is the additional challenge and new demands for reliable, coordinated assessment of student learning (Cohen et al., 2014). Van Ast (1999) notes, As faculty make and maintain the paradigm shift in the constructs of knowledge, students, purpose, relationships, context, and assumptions, community college movers and shakers at all levels and organizations must give as much priority time and resources to facilitating the paradigm shift as they are to nonteaching and learning priorities which presently drain their energy by de-emphasizing the commitment to the faculty ... one half the heart of the organization. (p. 569) 
Faculty in community and technical colleges are critical to the success of higher education in the United States. "With their mission of open access and affordability, the 'people's colleges' perform a great service to individuals, communities, states, and the country" (Wallin \& Smith, 2005, p. 101).

\section{Faculty Development}

Until the first part of the $20^{\text {th }}$ century, faculty members in higher education were not hired based on their educational expertise, background, and research agendas, but instead were selected to teach based on their religious affiliation, character, and other personal qualities (Gaff \& Simpson, 1994). Changes in evaluation of faculty competence, desired traits, and perceived roles reflect new expectations for academia, and the faculty who teach in all institutions of higher education. "In the 'Age of the Scholar' (1950s through early 1960s), the term faculty development referred primarily to practices for improving and advancing scholarly competence" (Beach, Sorcinelli, Austin \& Rivard, 2016, p. 5). Over the years, Faculty development has meant different things at different times and there is no universal definition of the term, but in essence faculty development can be described as activities that are designed to assist the faculty member in becoming a better teacher, a more competent professional, or a fully functioning person.

$$
\text { (Allen, 1988, p. 89) }
$$

The goal of faculty development in the 1950s was to further develop and refine discipline expertise. "Institutions created various mechanisms for encouraging their faculty to learn and to keep up to date in their fields - sabbatical leaves and support for such activities as completing an advanced degree, traveling to professional meetings, and conducting research" (Gaff \& Simpson, 1994, p. 168). 
Some of the earliest formal programming for faculty development began in the mid1960s to 1970s, which Beach et al. (2016) coin the "Age of the Teacher" (p. 5). There came to be new attention and a "realization that faculty should be not only be better prepared in their disciplines but also better able to teach" (p. 5). By the mid-70s, interest in faculty development was flourishing. Funding from private donors was supporting college and university campuses to create teaching and learning centers and teaching improvement programs. Founded in 1976, Professional and Organizational Development Network in Higher Education (POD) provided members personal and academic relationships for its faculty developer members, and is now the largest professional association in the world for the field (Beach et al., 2016).

The 1980s emphasized evaluation of faculty teaching effectiveness by way of indirect assessment of faculty development. "With widespread applications of faculty development programs, the next step was inevitable - the study of program effectiveness" (Boice, 1984, p. 4). Although teachers wished to improve their instruction, it was not immediately apparent how faculty development programs were helpful with limited evidence of effectiveness (Boice, 1984). In 1986, it was found that half of all baccalaureate institutions in the United States had some type of faculty development program (Millis, 1994). Student-centered learning and emphasis on the teaching and learning process was the focus in the 1990s in higher education. Angelo \& Cross (1993) note two principal fundamental questions of the '90s movement in Classroom Assessment Techniques, "How well are our students learning? How well are our teachers teaching?" The impact of technological advances on teaching and learning, coupled with "growing attention to assessment and performance measurement" (Beach et al., 2016), posed new opportunities for faculty development programs. 


\section{Faculty Development in Community Colleges}

Studies about community college teaching suggests that faculty competency and confidence is essential to effective teaching and learning (Van Ast \& Mullen, 1999). "National surveys of higher education faculty report a strong commitment to their work and a desire for high-quality professional development” (Gyurko, MacCormack, Bless, \& Jodl, 2016, p. 6). Hart Research Associates (2015) found that 9 in 10 higher education faculty members believe that professional development is important to their careers and would help improve student outcomes. Hamblin (2015) suggests that faculty development programs in the community college must include the opportunity for faculty to reflect upon the assumptions and frames of reference that they bring to the classroom. "Teachers [need] to think critically about their own understanding of what it means to be a community college teacher” (p. 32). Faculty development in community colleges is guided by specific goals and outcomes. Smith (2007) emphasizes,

Unlike faculty at four-year schools, where symposia, colloquia, and seminars within an academic discipline are the center of the professional development agenda, the needs of the community college faculty are different. Therefore, the topics we [community college faculty] must address include not only the educational and academic, but also those related to personal growth and teaching. (p. 24)

Although many community colleges report spending considerable amounts on faculty development, some faculty do not feel the necessity to personally participate. Despite this, they readily express their beliefs about colleagues that need further training and development (Murray, 2000). Angelo (1994) comments, 
A relatively small number of faculty take advantage of the [faculty development] programs. Those faculty who do participate are often the ones who seem to need them least; and most faculty development efforts seem to result in little if any measurable, long-term improvement in teaching and learning. (p. 3)

Elliott and Oliver (2016) conducted an assessment to explore the relationship between community college faculty professional development and the academic achievement of diverse students. Findings suggested "faculty involvement in professional development activities has important effects on student academic achievement in terms of student perceptions of faculty effectiveness" (p. 93). Although the focus of this study was collecting and analyzing data related to the impact of faculty development on student learning outcomes, it is important to note that one theme from the findings revealed the institution had "no data-driven means for assessing the effectiveness of faculty development” (p. 90). Faculty evaluated their use of instructional strategies by looking at student scores on exams and quizzes in isolation from other professional perspectives in a more formal assessment and accountability process (Elliott \& Oliver, 2016).

Opportunities for faculty development commonly used in the community college include discipline-specific training and release time for independent development and retreats. Workshops, another popular method of faculty development, tend to focus on pedagogy or other instructional strategies offered by the institution (Cohen \& Brawer, 1996), mostly because of the flexibility and variety of teaching methods used to promote skill acquisition (Steinert, 2010). Yet, a recent study by Hamblin (2015) found that faculty valued professional development opportunities for active learning, critical reflection, and peer group conferencing, more than the traditional workshop or lecture. "They valued learning experiences that were reflective and 
applicable to the classroom" (p. 115), which is consistent with social learning - and opposed to the limiting constraints of the traditional workshop model.

Institutions should make the use of student-centered methods for teaching a priority in faculty development programs if they want faculty to recognize their existence and importance (Fishback et al., 2015). Programs that highlight student-centered strategies should be designed to focus on teaching and learning as a process;

The learning outcomes might include the ability to identify aspects of the career professions or academic disciplines; understand the structure, function, and operation of each department, program, division and college; find new skills to improve teaching; and develop awareness of ways to promote wellness and personal growth. (Smith, 2007, p. 25)

Some faculty believe they do not have a role in student success; that it is inevitable that some students will succeed and some will not (Perez, McShannon, \& Hynes, 2012). Additionally, Fishback et al. (2015) found,

Faculty had negative comments, stating that students needed to be entertained, that those who do not thrive in an active classroom should not be in college, and that they were constrained in their teaching by the institution and content requirements of the course. (p. 3)

Perez, McShannon, and Hynes (2012) also state, While faculty can ask students to do their homework and come to class prepared, in reality, they cannot make students prepare for class, or even to come to class. However, faculty can change their own behavior in an effort to increase student success. (p. 379) 
By engaging in learning about instructional practices that impact student success, faculty may become more confident, and subsequently, more effective teachers. Additionally, teacher efficacy beliefs "influence teacher goals and persistence, which in turn affects teaching behaviors" (Fives \& Buehl, 2010, p. 119). Malnarich (2008) explains “Good faculty development brings relevant scholarly work on teaching and learning to faculty attention ... No faculty development program will thrive that sets out to "fix" faculty" (p. 1).

A historical review of community colleges, community college faculty, and community college faculty development presents several key points of significance. First, community colleges hold a unique role in being held accountable for workforce development, workforce retraining, developmental instruction, and preparation for transfer success. In these expectations is an assumption that community college faculty will demonstrate competency regarding occupational skill attainment or general study preparation. National trends regarding accountability also mean that community college faculty are expected to understand and demonstrate effective classroom management techniques, student engagement activities, and strategies for good instruction. "Professors today are facing a growing array of changing roles and responsibilities that will require them to engage in ongoing professional growth" (Sorcinelli, 2007, p. 5).

Participation in faculty development plays a key role in faculty motivation, satisfaction with their careers, and can improve the academic experience for students (Rowbotham, 2015). Programs for "teaching as well as learning as a process, identity, and profession are all important parts of the professional development process" (Smith, 2007, p. 25). Faculty can develop greater self-efficacy and improved confidence in their teaching with the knowledge gained from faculty 
development programs (Rowbotham, 2015). The problem is there are few studies available to provide data-driven guidance pertaining to effective community college faculty development.

\section{Faculty Development and Teacher Efficacy}

In the age of accountability, community college faculty need to partake in professional development to cultivate strategies and practices for dealing with the wide variety of educational attainment, technology skills, and age differences they will encounter with their students (McClure, 2011). Quality professional development opportunities to address these differences have the potential to positively impact teaching practices (Gyurko, MacCormack, Bless, \& Jodl, 2016). "The creation and evaluation of a faculty development program can aid in the formation of best instructional practices and increase the competency of faculty in meeting the challenges of educating students" (Rowbatham, 2015, p. 5). Although researchers have concluded that faculty development has no universal definition (Allen, 1988; Beach et al., 2016), those activities within models of faculty development "are designed to assist the faculty member in becoming a better teacher, a more competent professional, or a fully functioning person” (Allen, 1988, p. 92). As teaching and learning grows more complex, there is a strong call for faculty to use highimpact, evidence-based practices, and research-based inquiry approaches to improve their teaching practices for student learning (Beach et al, 2016).

The traditional teaching methodologies (e.g., lectures and tests) are becoming obsolete in a world that encourages people to think critically and creatively. New forms of pedagogy, active learning, self-guided instruction, and group work are transforming teaching approaches, moving them away from traditional lectures to passive audiences. (Hainline et al., 2010, para. 2) 
These new developments create a changing landscape for faculty development that may no longer adhere to the "training paradigm that dominates the world of teachers' professional development" (Little, 1993, p. 141). However, it should be noted, according to Cohen et al. (2014), "Traditional classroom instruction, that is, one teacher interacting with a number of students, still dominates" (p. 179).

The traditional training model places teachers in passive roles as consumers of knowledge produced elsewhere (Little, 1993). These conventional models of formal professional development such as workshops and seminars "take only superficial account of teachers' histories or circumstances, and doesn't account for the complexity, subtlety, and uncertainties of the classroom" (Little, 1993, p. 138). These models may be ineffective and inadequate, in producing changes in the way faculty teach. According to Little (1993), forms of professional development that are grounded in training "are poorly conceived to help people expand the possibilities for learning, teaching, and schooling" (p. 140) because there is little opportunity for expansion of information sharing, intellectual discussion, and critical reflection.

Faculty development programs should be centered around the actual needs of faculty and responsive to building a teachers' sense of efficacy (Fritz, Miller-Heyl, Kreutzer, \& Macphee, 1995). Additionally, programs "must be constructed in ways that deepen the discussion, open up the debates, and enrich the array of possibilities for action" (Little, 1993, p. 148). Providing traditional faculty development programs designed to merely introduce new knowledge or skills, such as in the traditional training model, with no opportunities for practice and reflection, will be ineffective for change and improvement. "A traditional, but often overlooked, problem supporting the need for faculty development programs is the general lack of preparation one receives for the teaching profession" (Allen, 1988, p. 90). For example, implementing student 
retention programs is an expressed need, but one in which faculty feel ill-prepared (Wallin \& Smith, 2005).

Wallin and Smith (2005) report, "Faculty are confident in their content areas" (p. 100), but,

...getting students to develop the ability to go beyond course content and rote memorization to application and critical thinking is a concern for faculty. They are unsure of how best to go about achieving this very important objective. Faculty development activities that address this need could be very beneficial and appreciated. (p. 98)

Some studies have found that "faculty tend to spend their limited time and resources on getting better at what they were already good at - usually subject matter content" (Fishback et al., 2015, p. 6), versus engaging in a faculty development program designed for increasing competencies in new areas. Other studies have found developmental activities related to a faculty's discipline is more effective than generic teaching tips (Lail, 2005). Faculty who do attend faculty development programs almost always involve a "minority of faculty members... many times the very faculty members (early adopters of new technology, strategies, and teaching practices) who least need to improve" (Allen, 1988, p. 94).

One explanation for the participation of competent teachers in faculty development activities is that these activities pose no threat to them. A weaker teacher could view faculty development as a form of evaluation and maybe not be interested in sharing his or her deficiencies with the instructional staff. Perhaps teachers are better than average or competent because they participate in such things as faculty development, or perhaps it works the other way around. (Allen, 1988, p. 95) 


\section{Social Learning for Community College Faculty Development}

The diversity of students at community colleges "requires faculty who possess the confidence and ability to use student centered techniques" (Fishback et al., 2015, p. 1), and are acutely "aware of the importance of developing and modifying the curriculum they teach" (Wallin \& Smith, 2005, p. 93). With the need for revised approaches to curriculum and instruction to meet the needs of today's student, a standard recommendation by administrators has been to place an emphasis on the preparation of faculty. This emphasis has been on both the goals of the community college and the concerns of students (Cohen \& Brawer, 1996), although "the initiative for faculty development should come primarily from faculty" (Allen, 1988, p. 94).

A study by Wallin and Smith (2005) regarding faculty development needs in two-year colleges found that "faculty recognize the importance of using technology to organize and manipulate student information, but they also indicate a low degree of confidence in their ability to do so" (p. 98). "Participating in innovative program development is also an opportunity they would like to experience, but have low confidence in their ability" (p. 99). Other findings from the study revealed that community college faculty members feel they do not have an understanding of how to integrate their curriculum with other faculty in their departments, or with other instructional areas for a better experience for their students.

In $21^{\text {st }}$ century learning, "The instructor is no longer the sage the on stage in classrooms and lecture halls, and often serves multiple roles through interactions with students that include teacher, mentor, and adviser" (Hainline et al., 2010, para. 3). To best meet the needs of students, "There will need to be a concerted focus on faculty development to train instructors in new pedagogies utilizing active learning and educational technology" (Hainline et al., 2010, para. 7). Faculty should be confident in their ability to influence student learning, student motivation, and 
student engagement. Successful completion of an instructional activity is based not only on one's ability to perform the activity, but also on one's beliefs that they are capable of implementing (Younger, 2011).

Studies have proved highly efficacious teachers positively influence student achievement (Gabriele \& Joram, 2007; Hardre \& Sullivan, 2009; Patrick, Kaplan, \& Ryan, 2011; Ross, 1994; Turner, Christensen, Kackar-Cam, Trucano, \& Fulmer, 2014), student motivation (Mojavezi \& Tamiz, 2012), and are more open to new teaching methods (Allinder, 1994; Guskey, 1998). Woolfolk and Hoy (1990) state, "researchers have found few consistent relationships between characteristics of teachers and the behaviour [sic] or learning of students... teachers' sense of efficacy is an exception to this general rule" (p. 81). A teachers' sense of efficacy is defined as the situation-specific belief that a teacher holds regarding his or her abilities and skills to positively impact student motivation and achievement (Gavora, 2010; Gibson \& Dembo, 1984; Tschannen-Moran \& Woolfolk Hoy, 2001). Therefore, it is important to examine teachers' selfefficacy and the extent of influence it places upon a student's performance and achievement (Kahn et al., 2015; Protheroe, 2008; Ross, 1994; Tschannen-Moran \& Woolfolk Hoy, 2001). Bandura's Social Learning Theory (1971), the associated concepts of self-efficacy (Bandura, 1977; 1994; 1997), perceived self-efficacy (Bandura, 1993), and teachers' selfefficacy (Gavora, 2010; Gibson \& Dembo, 1984; Ross, 1994; Tschannen-Moran \& Woolfolk Hoy, 2001) provide a conceptual framework for this study. "It [theoretical conceptualization of self-efficacy] also provides a frame through which to view faculty approaches towards teaching, and in particular, to what might or might not change faculty teaching-related behaviors" (Matney, 2001, p. 31). Most importantly, "self-efficacy theory provides a conceptual framework 
within which to study the determinants of effective work design and the mechanisms through which they enhance organizational functioning” (Bandura, 2009, p. 182).

Social learning is learning that occurs in a social context. The theory behind social learning suggests that behavior can be acquired or changed through observation of others via the concept of modeling (Bandura, 1971). Social learning enables us to learn by example. In support of this theory, Weimer (1990) argues "Individual faculty members can model instructional attitudes and activities that will influence the classroom decisions of their colleagues" (p. 136). Angelo (1994) also suggests that faculty often prefer learning from other faculty:

Given the differences between disciplines, it's not surprising that many faculty are skeptical of the idea that some 'developer' from outside their discipline can understand its specific teaching and learning issues. Even those faculty who avidly participate in faculty development often have trouble understanding the relevance of teaching innovations or suggestions from disciplines other than their own. This difficulty often arises because general ideas about teaching aren't translated into discipline-specific terms and concepts that a teacher of a particular course can act upon. (Such translations are most powerful and convincing when faculty make them for themselves, often by identifying analogous issues within their own experiences.) In other cases, what works well in general sometimes will not work at all in a specific setting. (p. 4)

Allen (1998) describes essential elements of a professional development program: "consideration of adult psychological development, adoption of a framework, a sense of the level of institutional awareness about faculty development, and encouragement of faculty to develop 
professionally" (p. 94). Faculty development can increase one's value of teaching, rekindle their motivation and enthusiasm, and improve their knowledge, behaviors, and teaching skills (Lancaster et al., 2014). Given this, providing faculty development with social learning theory as the foundation can speak to the needs of community college faculty. This model of faculty development may serve as an appropriate means to influencing the sources of teachers' selfefficacy for implementing best practices for teaching and learning in the community college setting.

\section{Bandura's Theory of Self-Efficacy}

According to Bandura (1977), a person's acknowledgement about their performance directly relates to his or her motivation for achievement. Self-efficacy beliefs control their thoughts and actions; how they feel, think, and motivate themselves (Bandura, 1997):

Whether people think productively, pessimistically, or optimistically and in self-enacting or self-debilitating ways; how well they motivate themselves and persevere in the face of difficulties; the quality of their emotional well-being they achieve and their vulnerability to stress and depression; and the life choices they make, which set the course of their life paths. (Bandura, 2009, p. 185)

According to social cognitive theory, self-efficacy is developed over time based on the interaction between person, behavior, and outcome (Bandura, 1997). Social cognitive theory, developed from social learning theory in 1986 by Albert Bandura, posits that learning occurs in a social context with a dynamic and reciprocal interaction of the person, environment, and behavior. As a person chooses and executes a behavior, those around them (including factors of the environment) provide the consequences and feedback that helps to inform self-efficacy and behaviors in the future. Over time, the individual begins to gain a perception of the degree to 
which his or her actions have produced the desired outcome and subsequently, he or she develops a sense of self-efficacy (Bandura, 1977). As efficacy levels are increased through repeated successes, the potential for any negative impact that may arise through failures is likely to be limited (Bandura, 1977).

Self-efficacy is the perception that one can execute a course of action, not the actual ability to carry it out. "Self-efficacy is distinct from other conceptions of self, such as selfconcept, self-worth, and self-esteem, in that it is specific to a particular task, and has to do with self-perception of competence rather than actual level of competence” (Tschannen-Moran, Woolfolk Hoy, \& Hoy, 1998, p. 210). Through the ongoing process of self-reflection, individuals make an assessment of motivation, values, and efficacy in a variety of different circumstances and tasks. These tasks lead to beliefs about their efficacy and are developed by four main sources of influence. These include: (a) mastery experiences (b) social models (c) social persuasion, and (d) inferences from physical and emotional states (Bandura, 1977).

Mastery experiences. "The most effective way of instilling strong self-efficacy is through mastery experiences" (Bandura, 2009, p. 185). When an individual is successful in a task, their self-expectations increase. Bandura (2009) describes mastery experiences as opportunities in "overcoming obstacles through perseverant effort. The route to high attainments is strewn with failure and setbacks. Success is achieved by learning from mistakes.... manage failure so that it is informative rather than demoralizing" (p. 185).

Social modeling. Social modeling is characterized by seeing success in people similar to one's self. This causes an increase in the observers' beliefs of their own abilities. Self-efficacy beliefs can increase through vicarious experiences, or watching others in situations that someone may feel is successful or threatening (Bandura, 2009). "Competent models convey knowledge, 
skills, and strategies for managing task demands. By their example in pursuing challenges, models foster aspirations and interest in activities" (Bandura, 2009, p. 185).

Social persuasion. The third source of influence is social persuasion. When a person is convinced that they should believe in themselves through positive encouragement, Bandura (2009) argues that they will exert more effort.

Effective efficacy builders do more than convey faith in others. They arrange situations for others in ways that bring success. They avoid placing them, prematurely, in situations where they are likely to fail. They measure success by self-improvement, rather than by triumphs over others. Pep talks, without enabling guidance, achieve little efficacy. (p. 185)

This feedback can be particularly useful when a task is ill defined or lacks objective criteria (Morris \& Usher, 2011).

Physical and emotional states. The final source of influence on self-efficacy is the reliance on physical and emotional states to judge one's efficacy, or perceive one's capability. In this situation, a person would consider factors like anxiety or fatigue as sign of personal deficiency. Contrary, a positive mood or positive energy would be associated with a greater sense of efficacy (Bandura, 2009).

\section{Teacher Efficacy}

Teaching efficacy of faculty members in higher education has a positive influence on teaching performance and students' learning achievement (Duong, Nguyen, \& Nguyen, 2017). A faculty's perception of their own knowledge, skills, and experience is significant for effectively overcoming difficult situations in the classroom (Savas, Bozgeyik, \& Eser, 2014). "Efficacy affects the effort they [teachers] invest in teaching, the goals they set, and their level of 
aspiration" (Tschannen-Moran \& Woolfolk Hoy, 2001, p. 783). The concept of teacher efficacy was derived from Rotter's self-efficacy theory "locus of control” (1966). Further investigation of the concept was based on Bandura's framework of self-efficacy (1977) and Bandura's social cognitive framework (1986). In a comprehensive review of the teacher efficacy literature by Rotter, Bandura, and other theorists, Tschannen-Moran et al. (1998) proposed integrating these concepts into a single model that was consistent with "the substantial body of research" (p. 227) related to teacher efficacy. This model is depicted in the diagram provided in Figure 1.

Tschannen-Moran and Woolfolk Hoy (2001) define a teacher's self-efficacy belief as “a judgement of his or her capabilities to bring about desired outcomes of student engagement and learning, even among those students who may be difficult or unmotivated" (p. 784). Faculty with higher levels of self-efficacy typically are more motivated (Mojavezi \& Tamiz, 2012), have greater levels of planning and organization (Gibson \& Dembo, 1984), have more patience with struggling students, are less critical of students when they make errors, and show more enthusiasm for teaching (Tschannen-Moran \& Woolfolk Hoy, 2001). Faculty with a stronger sense of efficacy "are more open to new ideas and are more willing to experiment with new methods to better meet the needs of their students" (Protheroe, 2008, p. 43). 


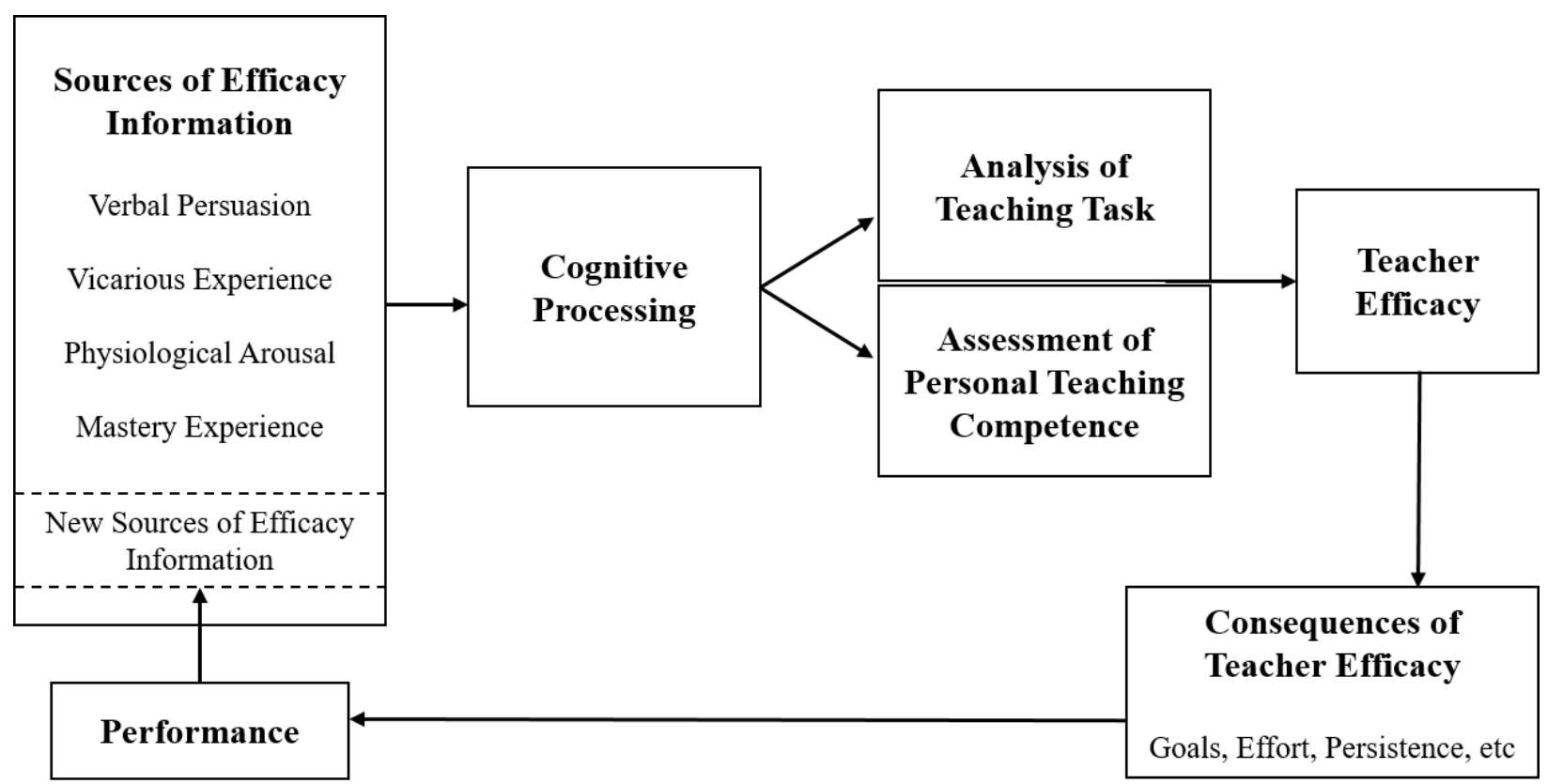

Figure 1. The cyclical nature of teacher efficacy. Adapted from "Teacher-efficacy: Its meaning and measure", by Tschannen-Moran, Woolfolk Hoy, and Hoy, 1998, Review of Educational Research, 68(2), p. 228.

It is important to note that "teachers do not feel equally efficacious for all teaching situations" (Tschannen-Moran et al., 1998, p. 227), and teacher efficacy "must be viewed as subject-matter specific" (Morris \& Usher, 2011, p. 239).

Ross (1994) describes two types of teacher efficacy; personal teaching efficacy and general teaching efficacy, both of which impact teacher performance:

Personal teaching efficacy is the respondent's expectation that he or she will be able to bring about student learning; general teaching efficacy is the belief that the teacher population's ability to bring about change is limited by factors beyond their control. The first is much closer to Bandura's self-efficacy, representing the belief that the individual will be able to perform the actions that lead to student 
learning. The second is more like outcome expectancy: the belief that certain actions will lead to learning. (p. 5)

Fritz et al. (1995) determined that teachers with higher personal efficacy may invest more time and effort in classroom activities. This is consistent with the work of Stein and Wang (1988) finding "highly efficacious teachers are more innovative" (p. 205). They also found that when participating in faculty development, teachers demonstrated greater competency in meeting student needs, increased satisfaction with their professional role as a teacher, and perceived fewer external constraints on student learning.

As noted with the concept of self-efficacy, it is important to differentiate between teacher efficacy and a teacher's competency - "usually interpreted and/or applied to refer to the teacher's professional knowledge and skills" (Gavora, 2010, p. 2). As a much broader concept, Gavora (2010) argues that teacher efficacy influences and facilitates the use of professional knowledge and skills, or in the case of low self-efficacy, discourages it. Therefore, "The importance of examining teacher efficacy lies to the extent of influence it exerts upon student's performance" (Khan et al., 2015, p. 118).

Fishback et al. (2015) conducted a survey of four community colleges including full-time and adjunct faculty. A finding of the study revealed that faculty commonly lectured and found it difficult to incorporate active learning, feeling that their strategies were not aligned with student needs (p. 3). "Others had more negative comments, stating that students needed to be entertained, that those who do not thrive in an active classroom should not be in college, and that they were constrained in their teaching by the institution and content requirements of the course" (Fishback et al., 2015). As people with low self-efficacy are less likely to make an effort to 
change their work environment (Horvitz, Beach, Anderson \& Xia, 2014), faculty are not likely to change the structure of their teaching to a more student-centered approach. In contrast, "Those teachers who in general expect students to learn, and who have confidence in their ability to teach, may communicate higher expectations by providing less criticism to students (Gibson \& Dembo, 1984, p. 579).

\section{The Sources of Teacher Efficacy}

As teachers engage and perform in activities associated with the art of teaching and learning, they receive solicited and unsolicited feedback from others (students, colleagues, administrators, etc.) that influence the teaching environment. These environmental influencers impact their efficacy. Like self-efficacy, the sources of influence that build on teacher efficacy are: (a) mastery experiences (b) social models (c) social persuasion, and (d) inferences from physical and emotional states.

In the context of education, these refer to teachers' successful or unsuccessful experiences of teaching, observation of other teachers' experiences, the negative or positive feedback teachers receive from others like colleagues, and physiological and affective states teachers experience during a teaching-related event or task, such as satisfaction, pleasure, and anxiety. (Zonoubi, Rasekh, \& Tavakoli, 2017, p. 2)

Mastery experiences. “An important factor in the determination of a teacher's sense of efficacy is, not surprisingly, experience, or what Bandura (1977), calls performance accomplishments" (Protheroe, 2008, p. 43). These experiences can either be successes or failures. Mastery experiences are the most powerful source of efficacy information (Hoy \& Spero, 2005). A successful teaching experience increases a sense of self-efficacy and the opposite would occur in a negative teaching experience. A teacher perceives his or her 
competence through mastery experiences of teaching. Through their own experiences in teaching, faculty are able to self-assess to gain insight about his or her strengths and weaknesses in teaching areas such as classroom management, instruction, and evaluation of students (Tschannen-Moran et al., 1998). Morris and Usher (2011) found that early successful instructional experiences, which involve a combination of mastery experiences and verbal persuasions, are important for developing high teacher efficacy in professors.

Social modeling. Social modeling, or learning through relevant vicarious experiences, affects the judgement of one's own capabilities to learn, hence influencing self-efficacy beliefs (Boz \& Boz, 2010). Bruce and Ross (2008) suggest that inviting faculty models to teach other faculty in professional development could enhance an instructor's self-efficacy. When faculty listen to stories about the accomplishments of their colleagues, they gain efficacy (Shavaran et al., 2012). Moreover, when faculty learn by watching each other teach, from the perspective of an observer, or even by viewing a digital resource, natural impressions about the art of teaching can be made through this experience (Tschannen-Moran et al., 1998). Tschannen-Moran et al. remark

Models of successful teachers are the bases for deciding that the teaching task is manageable and that situational and personal resources are adequate. Watching others teach in skillful and adept ways - especially observing admired, credible, and similar models - can affect the observer's personal teaching competence. (p. 230)

Social persuasion. Social persuasion, which can be general or specific, also plays a key role in building teacher efficacy. It can be a way of providing information about how one teaches, giving encouragement and strategies for overcoming situational obstacles, and providing specific feedback about a teacher's performance (Tschannen-Moran et al., 1998). For example, 
“appraisal by colleagues or supervisors about a particular act of teaching would enhance one's self-efficacy" (Boz \& Boz, 2010, p. 281). Social persuasion can also contribute to successful performances in the case that a positive persuasive boost leads a teacher to try out or test new strategies (Bandura, 1982). Personal teaching competence may be lowered by performance feedback from supervisors, other teachers, or even students if it is harsh, critical, and unconstructive. In this circumstance, teachers may adopt the self-protective strategy, which results in the belief that the teaching competence was never achievable in the first place (Tschannen-Moran et al., 1998).

Physical and emotional states. Finally, in placing judgement on one's ability to produce a desired result, emotional (such as stress) and environmental (such as work environment) inferences are indications of success or failure (Bandura, 1994). When people experience and perceive emotional states, these emotions directly influence their self-efficacy. "How well the individual feels about what can be accomplished makes an impact on the effort exerted and persistence employed" (Shavaran, 2012, p. 177). Therefore, "the level of emotional and physiological arousal a person experiences in a teaching situation adds to self-perceptions of teaching competence” (Tschannen-Moran et al., 1998, p. 229).

\section{Teacher Efficacy for New Faculty}

Research has found that new teachers who had a high sense of teacher efficacy found greater satisfaction in teaching, had a more positive reaction to teaching, and experienced less stress (Hoy \& Spero, 2005).

Faculty with a limited knowledge base in the process of education and with little teaching experience would have less of a sense of control over the teaching-learning environment and, consequently, would have a weaker sense of teacher self-efficacy than might be seen 
in more knowledgeable and experienced faculty. (Nugent, Bradshaw, \& Kito, 1999, p. 231)

Bandura's theory of self-efficacy suggests that efficacy may be most impressionable during the early stages of learning, thus the first few years of learning experiences for faculty could be critical to their long-term development of teacher efficacy (Hoy \& Spero, 2005). As previously noted, mastery experiences are the most powerful source for building teacher efficacy (Tschannen-Moran et al., 1998). Through mastery experiences, a faculty member's perception of their successful teaching raises efficacy, while a negative perception of one's teaching or failure lowers efficacy beliefs. Because of the limited exposure to mastery experiences, new faculty have not had a sufficient opportunity to build on the sources of teacher efficacy. Nugent et al. (1999) found that teaching experience and formal education positively influenced teacher efficacy. These findings further support the notion that new faculty should be exposed to opportunities for building upon the sources of teacher efficacy, thus helping to improve their efficacy beliefs.

Social modeling is important for new faculty. Faculty development programs and peer mentoring offer great opportunities for new faculty to observe and learn from their more experienced peers. Hoy and Spero (2005) note, "The more closely the observer identifies with the model, the stronger the impact on efficacy" (p. 345). Zonoubi et al. (2017) concluded that both new and experienced teacher's self-efficacy improved through collaborative reflection and peer observation as a component of a professional development intervention. "The experienced teachers' pedagogical self-efficacy improved in terms of learning more innovative teaching strategies" (p. 5). New faculty efficacy improved twofold; they gained more confidence in their own decision-making, and their efficacy in classroom management increased. The feedback new 
faculty received from supervisors and experienced faculty provided opportunities for mastery experiences and social persuasion - two components of building teacher efficacy. This allowed them to "grow more reliant on their own understanding of their teaching context and less dependent on their teacher guides and techniques dictated in training” (Zonoubi et al., 2017, p. 6). Contrary to these findings, Shavaran et al. (2012) argue there is no relationship between years of teaching service and levels of teacher efficacy. Findings from their study revealed new and experienced faculty were not shown to possess differing levels of teaching efficacy.

\section{Application of Bandura's Social Learning Theory}

Bandura's (1971) social learning theory "assumes that modeling influences produce learning principally through their informative functions and that observers acquire mainly symbolic representations of modeled activities rather than specific stimulus-response associations" (p. 6). In other words, social learning theory suggests that new behaviors can be acquired through the observation of others via the concept of modeling; that people can regulate their behavior in response to something they witness as an observation or engage in as a firsthand experience. If our learning relied solely on our own actions of trial and error, "it would be exceedingly laborious, not to mention hazardous" (Bandura, 1977, p. 22). Most human behavior is learned observationally. New behaviors are performed, and then on later instances, the coded information serves as a model for the observer's performance (Bandura, 1977). This observation of learning, which includes cognitive and behavioral views, is also referred to as social learning. “Man's capacity to learn by observation enables him to acquire large, integrated units of behavior by example without having to build up the patterns by tedious trial and error" (Bandura, 1977, p. 2), meaning, we are able to learn by example. There are four components of social learning: 
1. Attentional Processes - Something is selectively observed in the environment. Observers must pay attention to learn and perceive benefit. The process is influenced by characteristics and conduct of the model. "The people with whom one regularly associates, either through preference or through imposition, delimit the types of behaviors that will be repeatedly observed and hence learned most thoroughly" (Bandura, 1977, p. 24).

2. Retention Processes - The observer must recognize and remember the behavior in symbolic form. This process depends on an observers' ability to code information. “Observational learning relies mainly upon two representational systems - imaginal and verbal" (Bandura, 1977, p. 25). Symbols serve as guides for performance.

3. Motor Reproduction - The observer converts symbolic representations into action; however, the observer must be physically and intellectually capable of producing said action. "Ideas are rarely transformed into correct action without error on first attempt (Bandura, 1977, p. 28). Corrective adjustments are usually necessary.

4. Motivational Processes - There is a distinction between acquisition and performance, in addition to a presence of reinforcement or punishment. "Among the countless responses acquired observationally, those behaviors that seem to be effective for others are favored over behaviors that are seen to have negative consequences" (Bandura, 1977, p. 28).

Given the four aforementioned components of social learning, A model that repeatedly demonstrates desired responses, instructs others to reproduce the behavior, prompts them physically when they fail, and then rewards them when they succeed, may eventually produce matching responses in most people. (Bandura, 1977, p. 29) 
Still, social learning does not guarantee that the observer will exhibit behaviors similar to the model. Although we are able to learn by example, there are numerous factors to consider when an observer fails to match the behavior of a model. Bandura (1977) notes this failure may result from:

Not observing the relevant activities, inadequately coding modeled events for memory representation, failing to retain what was learned, physical inability to perform, or experiencing insufficient incentives. (p. 29)

\section{Specific Areas of Teacher Efficacy \\ Classroom Management}

According to Brown (2012), every accredited college or university in the United States establishes a Code of Student Conduct in the student disciplinary system (p. 63). In the classroom, faculty members have the authority and obligation to manage the classroom environment. There is an expectation that faculty will implement best practices for student learning while simultaneously holding each student to a high academic standard, regardless of classroom disruption or distraction. "It can be a challenge for educators to effectively communicate their expectations to students and provide the structure that some will need in order to function in the classroom" (Mundschenk, Miner, \& Nastally, 2011, p. 1). Students may engage in a number of disruptive behaviors, such as "physically confronting another, verbal abuse or threatening another, interrupting the educational process by making remarks out of turn, side talking during a lecture, dominating the class discussion, or constantly challenging the professor" (Brown, 2012, p. 63). The challenge comes for faculty when they are faced with juggling the essential practice of ensuring student learning while subsequently managing the design and implementation of classroom routines, policies, and procedures, defined by Henderson (2016) as 
classroom management. "Good classroom managers choose management styles that match their instructional goals, classroom activities, and students' characteristics" (Dicke, Willing, Schmeck, \& Leutner, 2015, p. 2).

As the community college provides an accessible pathway to many in their aspirations of success, "it can be particularly arduous for first-generation college students" (Falcon, 2015, para. 2). Obstacles first-generation students face, including financial stability, family support, and lack of college readiness, contribute to difficulty in adjusting to college academically and socially (Stephens, Hamedani, \& Destin, 2014). Limited understanding of the expectations for the college classroom may bring forth inappropriate behavior, further challenging faculty to confidently manage disruptive incidents (Brown, 2012).

Teacher efficacy is impacted by how faculty manage their classrooms. This includes strategies aimed at increasing or encouraging desirable student responses through praise, encouragement, attention, and rewards. Simonsen, Fairbanks, Briesch, Myers, and Sugai (2008) identified evidence-based classroom management practices in five broad categories: (a) maximizing structure and predictability; (b) posting, teaching, reviewing, monitoring, and reinforcing expectations; (c) actively engaging students in observable ways; (d) using a continuum of strategies to acknowledge appropriate behavior; and (e) using a continuum of strategies to respond to inappropriate behavior. These management practices can be successfully incorporated in faculty development programming, but,

Unfortunately the potential benefits of PD [professional development] are lost if the teachers receive what is frequently described as "sit and get," which usually occurs over a short period of time (e.g., one-day) and does not involve follow-up monitoring or support. (Kennedy, Hirsch, Rodgers, Bruce, \& Lloyd, 2016, p. 48) 
Oliver and Reschly (2010) reviewed teacher preparation programs by examining course syllabi. Their study revealed that only $27 \%$ of U.S. universities devoted an entire course to classroom management, while the remaining $73 \%$ of courses, included classroom management content only as an integration with other subject areas.

Individuals with a high sense of teacher efficacy expect to be able to improve students' behavior and achievement while bringing about desired outcomes of student learning, despite difficulties such as adverse environmental influences (Tschannen-Moran and Woolfolk Hoy, 2001). A study by Dicke et al. (2015), assessed the Classroom Organization and Management Program, a professional development program developed by Evertson and Emmer in 2008, on new instructors in Germany. The results indicated this model of professional development, which includes group discussions, role-playing, and follow-up sessions, was effective in increasing participant levels of self-efficacy in the area of classroom management. Participants also reported lower levels of stress and classroom disturbances.

\section{Student Engagement}

Student engagement is influenced by a student's emotional commitment to his or her learning. "The more actively engaged students are - with college faculty and staff, with other students, with the subject matter they are studying - the more likely they are to persist in their college studies and to achieve at higher levels" (Community College Center of Student Engagement, 2017, p. 1). Student engagement has been shown to be related to better achievement at school, although disengagement has been shown to be related to school dropout, which can be seen as the result of a long-term process of disengagement. Research finds student engagement plays a role in college success (Collier, 2015), thus the importance of community college faculty to cultivate student engagement in the classroom. 
There are two basic components of student engagement: behavioral and emotional (Fredricks, Blumenfeld, \& Paris, 2004; Van Uden et al., 2014). Behaviorally engaged students participate, concentrate, put effort on assignments given, and do what they are asked to do. An emotional engagement with school brings about student enthusiasm, interest, identity with academics, and a positive learning attitude (Van Uden et al., 2014). There is distinction between these two components, however; they do not operate independently.

Self-efficacy theorists argue that teacher efficacy in student engagement significantly differs between teachers who employ new methods of instructional practices and those who employ traditional instructional practices in classrooms (Tschannen-Moran et al., 1998). For teachers to believe they have the ability to engage students, it is important that they are prepared with knowledge and skills regarding new and innovative teaching methodologies and practices to foster this engagement (Villegas \& Lucas, 2002). Callaway (2016) concluded that there is a positive relationship between teacher efficacy and student engagement. Contrary to these results, Van Uden et al. (2014) suggested there is a weak relationship between teacher efficacy and student engagement. The authors concluded that student engagement is better influenced by a teacher's interpersonal behavior; the actual behavior in interaction with students and the student's perception of this. Regardless of the teacher's perception or students' perception, both studies suggested "A positive relationship between student and teacher has been shown to be important for student engagement and achievement” (Van Uden et al., 2014, p. 22).

\section{Instructional Strategies}

Community college faculty have experienced a shift in focus and accountability from simply access to access and student success (Baldwin, 2014; Morest, 2012; Nunley et al., 2011; Toner, 2016). Guskey (1998) argues that change is a gradual and difficult process, therefore, 
teachers need continuous encouragement and support after participating in training with new concepts to help with the initial onset of low confidence. Tschannen-Moran et al. (1998) state, "As teachers develop new strategies to cope with the changes and gain evidence of improved student learning, their personal teaching efficacy increases" (p. 237). However, Ross (1994) explains that teachers' self-efficacy beliefs may be lowered when implementing new instructional strategies, but as they begin to see new strategies are effective, their efficacy will increase. Tschannen-Moran et al. (1998) further describe this process by Ross (1994):

(a) High teacher efficacy might contribute to experimentation and new teaching ideas by influencing teachers' goal settings. (b) Teacher efficacy could decline as the new techniques disrupted the smoothness of the new practice. (c) Efficacy beliefs might remain depressed even if there was early access if the perceived superiority of the new techniques persuaded teachers of the inadequacy of their routine practice. (d) Teacher efficacy might begin to increase as teachers integrate the new methods into their repertoire and begin to enjoy increased student performance consistently. (e) Enhanced efficacy might motivate the search for new skill development opportunities. (p. 238)

Faculty members' sense of self-efficacy impacts the choices they make when selecting teaching methods for the classroom (Fishback et al., 2015). McClenney and Peterson (2006) add, “The more community colleges understand about how faculty use class time and about the education practices they employ, the more they can support strategies that are highly effective in promoting student learning and success" (pg. 25). 


\section{Summary}

Faculty development at the community college level is essential in assuring faculty acquire the knowledge and skills required for their role in student success. For faculty to fully acknowledge and embrace their contribution to student success, they need to believe in their capabilities to positively affect student learning, even among those students who may be difficult or unmotivated (Tschannen-Moran \& Woolfolk Hoy, 2001). Being that self-efficacy does not focus on one's expertise or competence, rather on their beliefs about what they can accomplish, facilitating professional development that integrates social learning theory is an appropriate strategy for building efficacy (Shavaran et al., 2012).

Specific to this study is an understanding that a teacher's sense of self-efficacy, and efficacy in classroom management, student engagement, and instructional strategies, are important for student achievement, retention, and completion. Teacher efficacy is an indicator of one's future behaviors, decisions, and classroom organization (Shavaran et al., 2012). Aspects of social learning theory, which specifically speak to a means of increasing self-efficacy (Bandura, 1977), are present in variations of faculty development, but no study has previously sought to measure the effectiveness of social learning in community college faculty development. Additionally, there is limited understanding regarding the effectiveness of faculty development models that are explicitly designed to build on the sources of teacher efficacy. This study adds to the literature and provides data-driven recommendations regarding faculty development by exploring the effectiveness of a community college faculty development model grounded in social learning theory.

Chapter III will provide information on the specific methodology employed for generating and obtaining data for this study. The intended methods, including the research 
purpose, research design, study population, research variables, instrumentation, data collection methods, faculty development treatment, and the data analysis will also be reported. 


\section{CHAPTER 3}

\section{METHODOLOGY}

Chapter III provides methods and procedures. This study utilized a quantitative research approach to examine community college teacher efficacy beliefs and the effect of a faculty development model based upon social learning theory on these beliefs. A pre-experimental, onegroup, pre-test-post-test research design was employed, incorporating analysis of pre-existing survey data on overall teacher efficacy, and efficacy in classroom management, student engagement, and instructional strategies. This methodology enabled a comparison of the levels of efficacy prior to and after implementation of the faculty development program in an effort to disclose any influence of the faculty development treatment. The following sections in Chapter III more fully describe the research method and design including the variables, survey instrument, data collection, and the statistical analyses used to address the research questions.

\section{Research Purpose}

Community colleges are continuously being challenged to improve student success and completion, while increasing both access and quality (Boggs, 2012). The expectation of community college faculty is to respond to these needs by providing and ensuring optimum learning opportunities that reflect best-practices in teaching and learning. Faculty development programs provide faculty support and guidance regarding these expectations, but a key consideration is the extent to which such programs effectively influence faculty perceptions of their ability to meet such responsibilities. The purpose of this study was to determine the effect, if any, of professional development modeled upon social learning theory on community college teacher efficacy. 


\section{Research Design}

This study used a pre-experimental, one-group, pre-test-post-test research design to measure teacher efficacy change before and after participation in a faculty development treatment explicitly modeled on social learning theory. The treatment was developed by the Office of Professional Development at the case institution in an attempt to improve and enhance faculty skill in managing a classroom, cultivating student engagement, and implementing instructional strategies. The measurement of change on teacher efficacy was assessed through a pre-test, exposure to the treatment, and post-test (Marsden \& Torgersden, 2012). Individual differences in participants' overall levels of performance were controlled by comparing the scores of his or her pre-treatment scores to his or her own post-treatment scores, therefore better affirming treatment effects, if any (Lane, 2007). Marsden and Torgerson (2012) argue “... before and after data can determine the promise of an intervention during its development phase" (p. 593). This methodology was appropriate because it enabled a comparison of the levels of efficacy prior to and after implementation of the faculty development program in an effort to disclose any influence, thus showing any potential promise of this treatment. Surveys, including the Teachers' Sense of Self-Efficacy Scale (TSES), were used by the Office of Institutional Effectiveness at the case institution to collect teacher efficacy scores and to analyze the relationship between the independent and dependent variables.

\section{Research Questions}

The purpose of this study was to determine the effect, if any, of professional development modeled upon social learning theory on community college teacher efficacy. The following research questions framed this study: 
$\mathrm{RQ}_{1}$ : What effect, if any, does a faculty development program explicitly modeled upon social learning theory have on community college overall teacher efficacy?

$\mathrm{RQ}_{2}$ : What effect, if any, does a faculty development program explicitly modeled upon social learning theory have on community college teacher efficacy specific to managing a classroom?

$\mathrm{RQ}_{3}$ : What effect, if any, does a faculty development program modeled upon social learning theory have on community college teacher efficacy specific to cultivating student engagement?

$\mathrm{RQ}_{4}$ : What effect, if any, does a faculty development program modeled upon social learning theory have on community college teacher efficacy specific to implementing instructional strategies?

$\mathrm{RQ}_{5}$ : What effect, if any, does years of teaching experience have on community college overall teacher efficacy after participating in a faculty development program modeled upon social learning theory?

\section{Population and Sample}

Research was conducted at a large urban community college in southeastern United States. The college consists of seven campuses and a current enrollment of 80,000 students, with approximately 13,000 being transfer or degree-seeking. The student population consists of $66 \%$ female and $34 \%$ male, with $64 \%$ classified as non-traditional students age 21 or older. The college employs approximately 1200 part-time faculty, or $80 \%$ of the population, and 300 fulltime faculty, approximately $20 \%$. In comparison, post-secondary institution-level data collected by the Integrated Postsecondary Education Data System (Ginder, Kelly-Reid, \& Mann, 2017) 
revealed that two-year institutions in the United States employ, on average, 68\% part-time faculty, and $32 \%$ full-time faculty.

The participants of this study were all full-time, ranging from new to experienced faculty, and representing subject areas in general education and applied sciences, with varying backgrounds in education and experience. All participants teach in curriculum, degree-granting programs. For the purposes of this study, new faculty are categorized by those teaching less than four years. Faculty teaching four years or more are categorized as experienced faculty.

Full-time faculty were invited to participate in the treatment because of their requirement from the college to obtain a minimum of twenty hours of professional development opportunities per academic year. Part-time faculty are not required to obtain the annual minimum of twenty professional development hours or to participate in professional development beyond the required training of all employees. Additionally, part-time faculty are not paid, nor do they receive stipends to engage in faculty development. Participating in the faculty development program was voluntary and would earn each full-time faculty member ten hours of professional development credit. Additionally, this was an opportunity for faculty to participate in innovative program development for a better experience for their students (Wallin \& Smith, 2005). An invitation was directly extended by the Office of Professional Development to each potential participant via his or her college email address. Also, a call for faculty participation was published in the college's internal online broadcast list.

A statistical power analysis (Hunt, n.d.) was performed for sample size estimation. Calculation was conducted for a paired samples $t$-test to compare means, using a two-tailed result, $d=0.5$, Cronbach's $\alpha=.05$, and a power of .80 . Analysis was based on data from Karimi's (2011) published study, The Effects of Professional Development Initiatives on EFL 
Teachers' Degree of Self Efficacy, which compared the effects of professional development initiatives on English as a Foreign Language (EFL) teacher efficacy change over time. Based on the total population of approximately 300 full-time faculty at the case institution, the projected sample size needed for this study was $(n=34)$. Further supporting the needed sample size in the data analysis, Khelifa (n.d.) argues, “A commonly accepted value for a moderate sample size is 30 subjects" (p. 9).

\section{Research Variables}

The faculty development treatment explicitly modeled upon social learning theory was developed by the Office of Professional Development at the case institution and was delivered by tenured faculty, faculty developers, and learning assessment experts. The independent variables for this study were participation in the faculty development program and years of teaching experience. The dependent variables were any differences between pre-and post-test scores in the four areas of teacher efficacy: overall efficacy, classroom management, student engagement, and instructional strategies.

This research design measured the effect of faculty development on teacher efficacy in three steps: (1) the administration of a pre-test measuring the dependent variables; (2) the implementation of the faculty development treatment, or independent variable, to the participants using a social learning theory framework, and (3) the administration of a post-test that measured efficacy again. Details of each step are described in the data collection procedures.

\section{Instrumentation}

The instrument used to collect data pre- and post-treatment was through the use of a descriptive survey. The Association for Educational Communication and Technology (2001) reminds us: 
Descriptive studies report summary data such as measures of central tendency including the mean, median, mode, deviance from the mean, variation, percentage, and correlation between variables. Survey research commonly includes that type of measurement, but often goes beyond the descriptive statistics in order to draw inferences. (para. 5) Tschannen-Moran et al. (1998) note

Bandura applauded efforts to expand measures of teacher efficacy beyond single-item measures... he found most measures of teachers' sense of efficacy currently available too general. In order to be useful and generalizable, measures of teacher efficacy need to tap teachers' assessments of their competence across the wide range of activities and tasks they are asked to perform. (p. 213)

The Teachers' Sense of Self-Efficacy Scale (TSES) developed by Tschannen-Moran and Woolfolk Hoy (2001) was developed to gain a better understanding of matters that create difficulties for teachers in a wide range of school activities and associated tasks. Specifically, the TSES assesses teachers' sense of efficacy with respect to the teaching tasks involved in student engagement, classroom management, and instructional practices. See Appendix A for survey questions. Permission to use the TSES from the authors was obtained by the researcher (Appendix B). The demographic and personal characteristics questionnaire (Appendix C) provided additional insight regarding: (a) teaching experience (university), (b) teaching experience (community college), (c) teaching experience (secondary education), (d) highest degree or credential obtained, (e) years of working experience in field, and (f) learning/training preference.

There are two forms of the TSES scale: the short form (12 items) and long form (24 items). These scales can be used to evaluate the total efficacy construct: total score and subscale 
score (Tschannen-Moran \& Woolfolk Hoy, 2001). To reduce the length of the long form, four items assessing teacher efficacy for classroom management $(\alpha=.85)$, four items assessing teacher efficacy for student engagement $(\alpha=.78)$, and four items assessing teacher efficacy for instructional strategies $(\alpha=.74)$ were used to create the short form. Tschannen-Moran and Woolfolk Hoy (2001) recommend that the full scale (long form) be used with pre-service teachers because the factor structure often is less distinct for these respondents. The case institution's Office of Professional Development sought to better understand teacher efficacy of both new and experienced faculty, however, only the short form was used to ensure consistent measurement across all faculty surveyed.

The TSES instructs respondents to rate their own efficacy for each of three areas of teaching (classroom management, student engagement, and instructional strategies), and uses a nine-point Likert-type scale for responses ranging from 1 (nothing) to 3 (very little) to 5 (some influence) to 7 (quite a bit) to 9 (a great deal), with higher scores indicating stronger feelings. Along with assessing overall teacher efficacy, factor analysis from three separate studies of preservice and practicing teachers conducted by Tschannen-Moran and Woolfolk Hoy (2001) yielded three dimensions: Efficacy in Classroom Management, Efficacy in Student Engagement, and Efficacy in Instructional Practices. Furthermore, a factor analysis of the TSES examined by Fives and Buehl (2010) for practicing teachers also indicated that "a distinct three-factor solution was most appropriate, (Factor 1: classroom management; Factor 2: student engagement; Factor 3: instructional practices) mirroring Tschannen-Moran and Woolfolk Hoy’s (2001) findings” (p. 127). These factors are thought to provide results that are generalizable enough to assess teacher efficacy across a range of teaching tasks and activities, but specific enough to be useful in a variety of contexts (Tschannen-Moran et al., 1998). 
Questions such as "How much can you do to control disruptive behavior in the classroom?" and "How much can you do to help your student's value learning?" were posed in the survey. However, as this instrument was originally developed for pre-service and practicing teachers in secondary education, the word "children" was used. For the purposes of this study, the word "children" (in questions 6 and 11) was replaced with "student" to more accurately describe the learners taught by community college faculty (Appendix A). Table 2 shows the relationship between the research questions, variables, and survey questions. Reliability of the short form TSES was determined with Cronbach's Alpha, regarded as a measure of validity and accuracy for the interpretation of data (Tavacol \& Dennick, 2011). Table 3 shows reliabilities on the TSES for overall score efficacy construct, student engagement, instructional strategies, and classroom management.

Tschannen-Moran and Woolfolk Hoy (2001) examined the construct validity of the TSES by assessing the correlation of this measure and other existing measures of teacher efficacy: Rand items 1 and 2 (Armor et al., 1976), Gibson and Dembo's (1984) Teacher Efficacy Scale, the pupil control ideology form (1967), and the work alienation scale (1978). Overall scores on the TSES were positively related to the other measures as noted in Table 4, with the strongest correlations between the TSES and other scales as it relates to personal teaching efficacy (Tschannen-Moran \& Woolfolk Hoy, 2001). Tschannen-Moran and Woolfolk Hoy (2001 conclude:

The results of these analyses indicate that the OSTES (Ohio State Teacher Efficacy Scale; now referred to as TSES) could be considered reasonably valid and reliable. With either 24 or 12 items, it is of reasonable length and should prove to be a useful tool for researchers interested in exploring the construct of teacher efficacy. Positive correlations 
with other measures of personal teaching efficacy provide evidence for construct validity. (p. 801)

Table 2

Relationship between Research Questions, Variables, and Survey Questions

\begin{tabular}{ccc}
\hline Research question & Dependent Variable & Survey questions \\
\hline $\mathrm{RQ}_{1}$ & $\begin{array}{c}\text { Score difference in overall teacher efficacy } \\
\text { construct }\end{array}$ & $\mathrm{SQ}_{1}-\mathrm{SQ}_{12}$ \\
$\mathrm{RQ}_{2}$ & $\begin{array}{c}\text { Score difference in teacher efficacy specific to } \\
\text { establishing classroom management } \\
\mathrm{RQ}\end{array}$ & $\mathrm{SQ}_{1} \mathrm{SQ}_{6} \mathrm{SQ}_{7} \mathrm{SQ}_{8}$ \\
$\mathrm{RQ} Q_{4}$ & $\begin{array}{c}\text { Score difference in teacher efficacy specific to } \\
\text { cultivating student engagement } \\
\text { Score difference in teacher efficacy specific to } \\
\text { implementing instructional strategies }\end{array}$ & $\mathrm{SQ}_{2} \mathrm{SQ}_{3} \mathrm{SQ}_{4} \mathrm{SQ}_{11}$ \\
\hline Research question & Independent Variable & \\
\hline $\mathrm{RQ}$ & Faculty teaching experience & $\mathrm{SQ}_{10} \mathrm{SQ}_{12}$ \\
\hline
\end{tabular}

Table 3

Reliabilities on the Teachers' Sense of Efficacy Scale (2001), Short Form

\begin{tabular}{lccc}
\hline & $M$ & $S D$ & $\alpha$ \\
\hline Overall Score & 7.1 & .98 & .90 \\
Management & 6.7 & 1.2 & .86 \\
Engagement & 7.2 & 1.2 & .81 \\
Instruction & 7.3 & 1.2 & .86 \\
\hline
\end{tabular}

Note. Adapted from Tschannen-Moran \& Woolfolk Hoy, (2001). 
Table 4

Validity Correlations $^{a}$

\begin{tabular}{lllllllll}
\hline & OSTES & Instruct & Manage & Engage & Rand 1 & Rand 2 & GTE & PTE \\
\hline OSTES & & $0.89^{* *}$ & $.084^{* *}$ & $.087^{* *}$ & $.018^{* *}$ & $0.53^{* *}$ & $0.16^{* *}$ & $0.64^{* *}$ \\
Instruct & $0.84^{* *}$ & & $0.60^{* *}$ & $0.70^{* *}$ & 0.07 & $0.45^{* *}$ & 0.06 & $0.62^{* *}$ \\
Manage & $0.79 * *$ & $0.46^{* *}$ & & $0.58^{* *}$ & $0.29 * *$ & $0.46^{* *}$ & $0.30^{* *}$ & $0.45^{* *}$ \\
Engage & $0.85^{* *}$ & $0.61^{* *}$ & $0.50^{* *}$ & & $0.11^{*}$ & $0.47^{* *}$ & 0.06 & $0.58^{* *}$ \\
Rand 1 & $0.18^{* *}$ & 0.08 & $0.26^{* *}$ & $0.11^{*}$ & & $0.23^{* *}$ & $0.65^{* *}$ & $0.12^{*}$ \\
Rand 2 & $0.52^{* *}$ & $0.45^{* *}$ & $0.39^{* *}$ & $0.45^{* *}$ & $0.23^{* *}$ & & $0.13^{*}$ & $0.65^{* *}$ \\
GTE & $0.16^{* *}$ & 0.08 & $0.26^{* *}$ & 0.06 & $0.65^{* *}$ & $0.13^{*}$ & & 0.07 \\
PTE & $0.61^{* *}$ & $0.60^{* *}$ & $0.37^{* *}$ & $0.56^{* *}$ & $0.12^{*}$ & $0.65^{* *}$ & 0.07 & \\
\hline
\end{tabular}

Note. GTE $=$ General Teacher Efficacy (Gibson \& Dembo, 1984). PTE $=$ Personal Teacher Efficacy (Gibson \& Dembo, 1984). 'Above diagonal, long form (24 items); below diagonal, short form (12 items); ** $p<0.01$ (2-tailed); * $p<0.05$ (2-tailed). Adapted from TschannenMoran, M., \& Woolfolk Hoy, A., (2001), Teacher-efficacy: Capturing an elusive construct. Teaching and Teacher Education, 17, p. 783-805.

\section{Data Collection}

Approval to use existing data was obtained from the Institutional Review Board (IRB) of both the researcher's academic university and the community college case (Appendix F). Surveys to collect data pre- and post-treatment were administered by the case institution's Institutional Effectiveness department. Surveys were completed by participants before the first treatment session, and at closing of the final treatment session. The pre-test survey opened with questions regarding demographics and personal characteristics (Appendix C), followed by the 12 items on the short form TSES. Although there is a recommendation from the authors 
(Tschannen-Moran \& Woolfolk Hoy, 2001) that the full scale (long form) be used with preservice (new) teachers, the case institution's Office of Professional Development made the decision to use the short form for the purposes of consistency and increased participation. The post-test survey (Appendix D) opened with the 12 items from the short form TSES and concluded with questions to allow for qualitative analysis of participant feedback. Anonymized data sets with unique identifiers were obtained from the case institution's Institutional Effectiveness department for instrument matching purposes and to avoid duplicates in pairs.

\section{Faculty Development Treatment}

Designed by the Office of Professional Development and delivered by tenured faculty, faculty developers, and learning assessment experts, a six-week treatment modeled upon social learning theory emphasized the four components of observational, or social, learning: attentional processes, retention processes, motor reproduction, and motivational processes. Three face-toface sessions and one online session, as described in the program syllabus (Appendix E), provided opportunities for faculty to build on sources of teacher efficacy. A brief description of each session is as follows:

Session 1 (3 hours, face to face) - Observe. Session 1 opens with the pre-survey and personal characteristics questionnaire. This session was specifically designed to accentuate the first component of social learning theory - attentional processes. This is the process in which something is selectively observed in the environment. Social learning theory suggests that new behaviors can be acquired through the observation of others via the concept of modeling; that people can regulate their behavior in response to something they witness as an observation or engage in as a first-hand experience. Faculty participants observe pre-identified faculty models in best practices and exemplary teaching regarding establishing classroom management, 
cultivating student engagement, and implementing instructional strategies. Attentional processes are influenced by the characteristics and conduct of the model. Session 1 also builds on sources of teacher efficacy including, mastery experiences, social modeling, and physical and emotional states.

Session 2 (1 hour, online) - Question. Session 2 emphasizes the second and third components of social learning theory - retention processes and motor reproduction. Faculty participants continue to observe faculty models while recognizing their own behaviors to serve as a symbolic guide for performance. These symbolic representations are turned into action through assignments addressing content from session 1: establishing classroom management, cultivating student engagement, and implementing instructional strategies. Positive behaviors are reinforced through the social context of the program and from the observations of faculty models. Session 2 continues to build on the sources of teacher efficacy including, mastery experiences, social modeling, and social persuasion.

Session 3 (3 hours, face to face) - Practice. Session 3 remains focused on the motor reproduction component of social learning theory. Faculty participants continue to demonstrate and model behaviors observed from sessions 1 and 2: establishing classroom management, cultivating student engagement, and implementing instructional strategies. Corrective adjustments to behaviors are recommended by faculty models. Opportunities for reflection and feedback are explicitly encouraged. Additionally, session 3 continues to build on the sources of teacher efficacy including, mastery experiences, social modeling, social persuasion, and physical and emotional states.

Session 4 (3 hours, face to face) - Reflect. Session 4 builds on motivational processes, the fourth component of social learning theory. Faculty participants reflect on previous session 
activities while engaging in discussions regarding teaching strategies and continued skill development. Additional collaborative opportunities for practicing, modeling, and debriefing are included in this session. Positive and effective behaviors are favored over those that are not, increasing motivation for implementing new teaching strategies. Session 4 continues to build on the sources of teacher efficacy including mastery experiences, social modeling, social persuasion, and physical and emotional states. Session concludes with post-test survey.

\section{Data Analysis}

Pre-existing data were analyzed by employing $t$-tests to determine if there was a significant difference in teacher efficacy mean scores over time. Anonymized data sets from the case institution's Office of Institutional Effectiveness were electronically shared with the researcher and entered into SPSS ${ }^{\circledR}$ to allow for statistical analysis. Although the TSES instructed respondents to rate their own efficacy for each of three areas of teaching (classroom management, student engagement, and instructional strategies), using a nine-point Likert-type scale ranging from 1 (nothing) to 9 (a great deal), the responses were further categorized by the researcher into five groups; 1 (not at all), 2-3 (very little), 4-6 (somewhat), 7-8 (quite a bit), and 9 (to a great extent; Brown, 2010). Through this process, data were conceptualized further to discern logical links and connections in an attempt to make a more meaningful analysis (Given, 2008).

For each participant, scores were calculated pre- and post-test for overall efficacy and for each subscale of the TSES (Efficacy in Classroom Management, Efficacy in Student Engagement, and Efficacy in Instructional Practices). Subscale scores were based on the factor loadings of the TSES as presented in "Teacher-Efficacy: Capturing an Elusive Construct" (Tschannen-Moran and Woolfolk Hoy, 2001). Overall efficacy is a sum total of all 12 items in 
the survey. Classroom Management subscale scores are a sum of items 1, 6, 7, and 8 . Student Engagement subscale scores are comprised of items 2, 3, 4, and 11. For the Instructional Strategies subscale, the score is compiled by adding items 5, 9, 10 and 12. In the calculation of both the overall and subscale scores, each item held the same weight and contributed equally to the respective subscale score.

A $t$-test can determine if mean differences from pre- to post-test are statistically significant. Paired samples $t$-tests and descriptive statistics were used to measure the differences in mean scores for overall efficacy (Research Question 1), efficacy in managing a classroom (Research Question 2), efficacy in cultivating student engagement (Research Question 3), and finally, efficacy in implementing instructional strategies (Research Question 4). An independent samples $t$-test was used to measure the differences in mean scores for overall efficacy between new and experienced faculty over time (Research Question 5).

\section{Summary}

The purpose of this study was to determine the effect, if any, of professional development modeled upon social learning theory on community college teacher efficacy. Chapter III provided an overview of the methods and procedures utilized in this study including a description of the population, variables, instrumentation, and faculty development treatment. The survey questions and the relationship of those questions to the research questions and variables were also discussed. Finally, the method of data analysis entailing descriptive statistics and tests performed to answer the research questions were reviewed. Chapter IV will describe the findings of the study. Chapter $\mathrm{V}$ will include a summary, conclusions, and recommendations for implementing the findings of this study for future research. 


\section{CHAPTER 4}

\section{FINDINGS}

Community college faculty members represent a diverse group, with varying levels of educational attainment and proficiencies in classroom management, student engagement, and instructional strategies (Finley \& Kinslow, 2016). As a result, the purpose of this study was to determine the effect, if any, of professional development modeled upon social learning theory on community college teacher efficacy. This chapter presents the results and findings in five subsections: (1) preliminary analysis, (2) faculty demographics, (3) item level analysis, (4) efficacy subscale construct analysis, and (5) a summary of the findings. The following research questions guided this study:

$\mathrm{RQ}_{1}$ : What effect, if any, does a faculty development program explicitly modeled upon social learning theory have on community college overall teacher efficacy?

$\mathrm{RQ}_{2}$ : What effect, if any, does a faculty development program explicitly modeled upon social learning theory have on community college teacher efficacy specific to managing a classroom?

$\mathrm{RQ}_{3}$ : What effect, if any, does a faculty development program modeled upon social learning theory have on community college teacher efficacy specific to cultivating student engagement?

$\mathrm{RQ}_{4}$ : What effect, if any, does a faculty development program modeled upon social learning theory have on community college teacher efficacy specific to implementing instructional strategies? 
RQ5: What effect, if any, does years of teaching experience have on community college overall teacher efficacy after participating in a faculty development program modeled upon social learning theory?

\section{Preliminary Analysis}

Existing data for this study were obtained using the Teachers' Sense of Efficacy Scale (Tschannen-Moran \& Woolfolk Hoy, 2001; TSES), which contained 12 items, a pre-survey demographics/personal characteristics questionnaire, and post-survey follow-up questionnaire. All statistical analyses were conducted using SPSS® version 24 . There were 63 full-time faculty participants who completed the pre-test and 55 who completed the post-test. As the dependent variable in this study were differences between pre-and post-test scores in the four areas of teacher efficacy, eight cases were eliminated due to the absence of post-test scores. This yielded a total of 55 acceptable data sets.

Assumptions of $t$-tests are that differences from the pairs of data sets are normally distributed on an interval scale of measurement. Because this study utilized paired samples $t$ tests for data analysis, normality was examined for each construct using the Q-Q plot (Ford, 2017) from SPSS $®$ output. The scatterplot of scores for each construct (Figures 2-5) of observed versus expected values formed a relatively straight line, assuming normal distribution. 

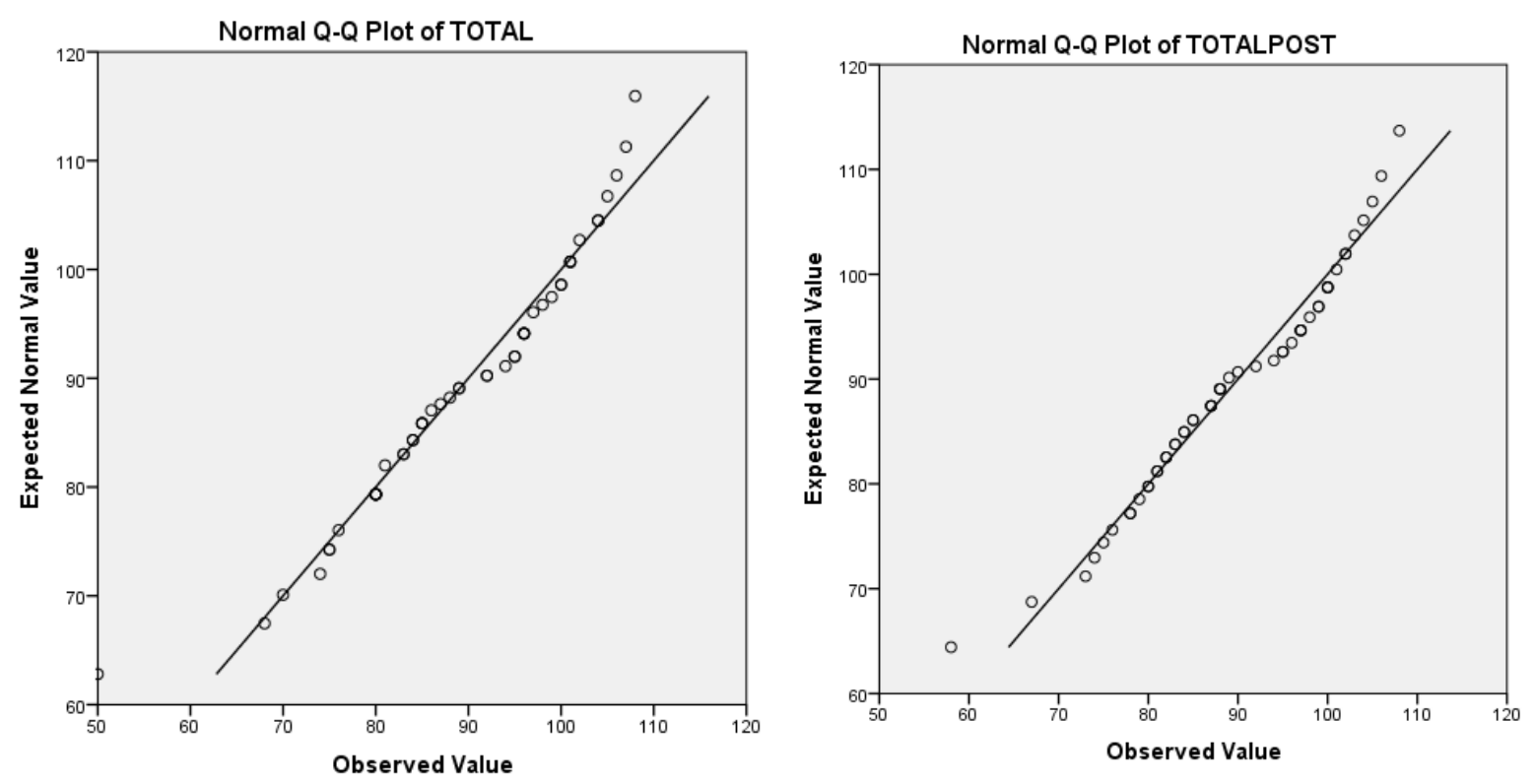

Figure 2. Normal Q-Q plots of the calculated pre- and post-test overall (total) teacher efficacy scores.
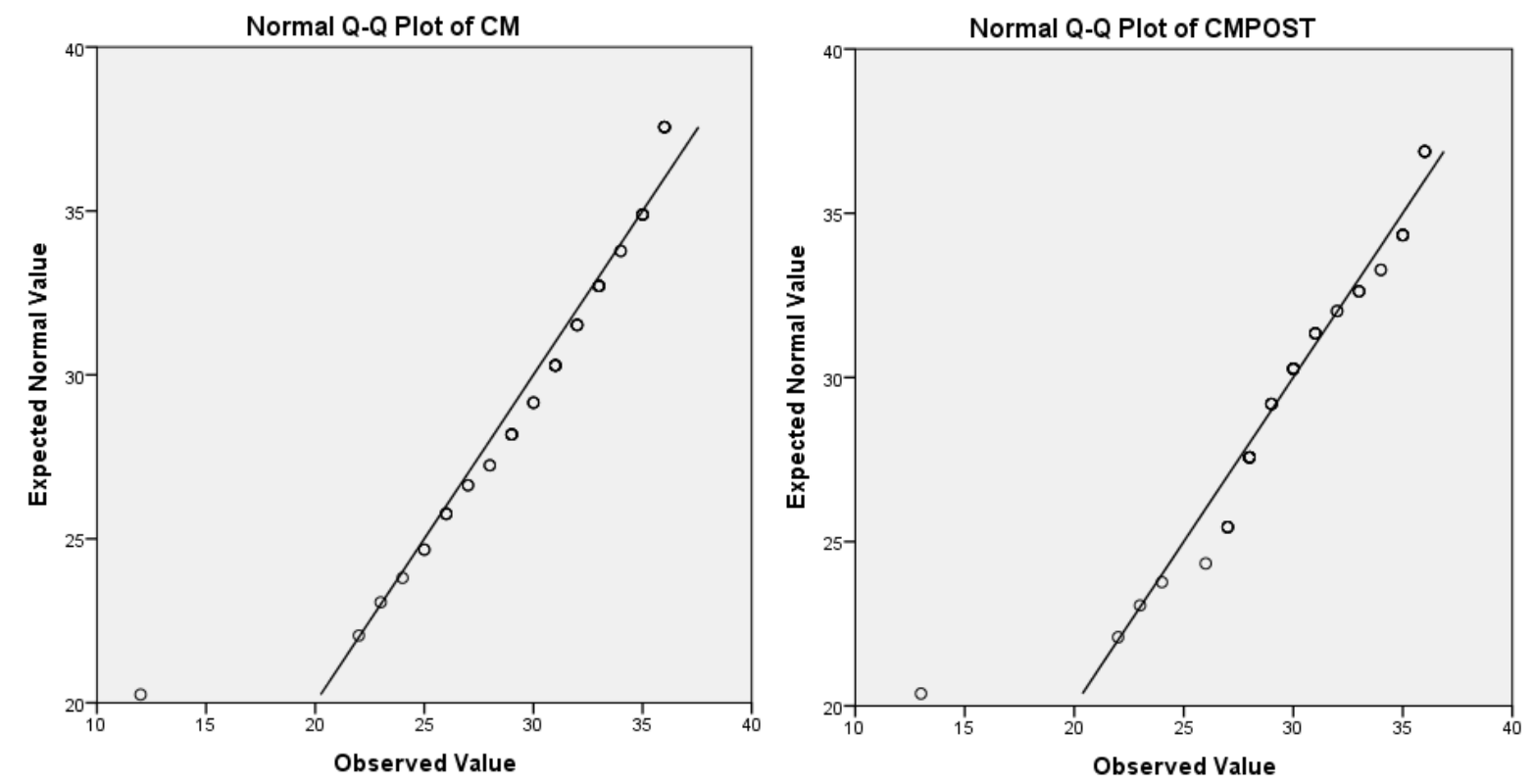

Figure 3. Normal Q-Q plots of the calculated pre- and post-test classroom management teacher efficacy scores. 

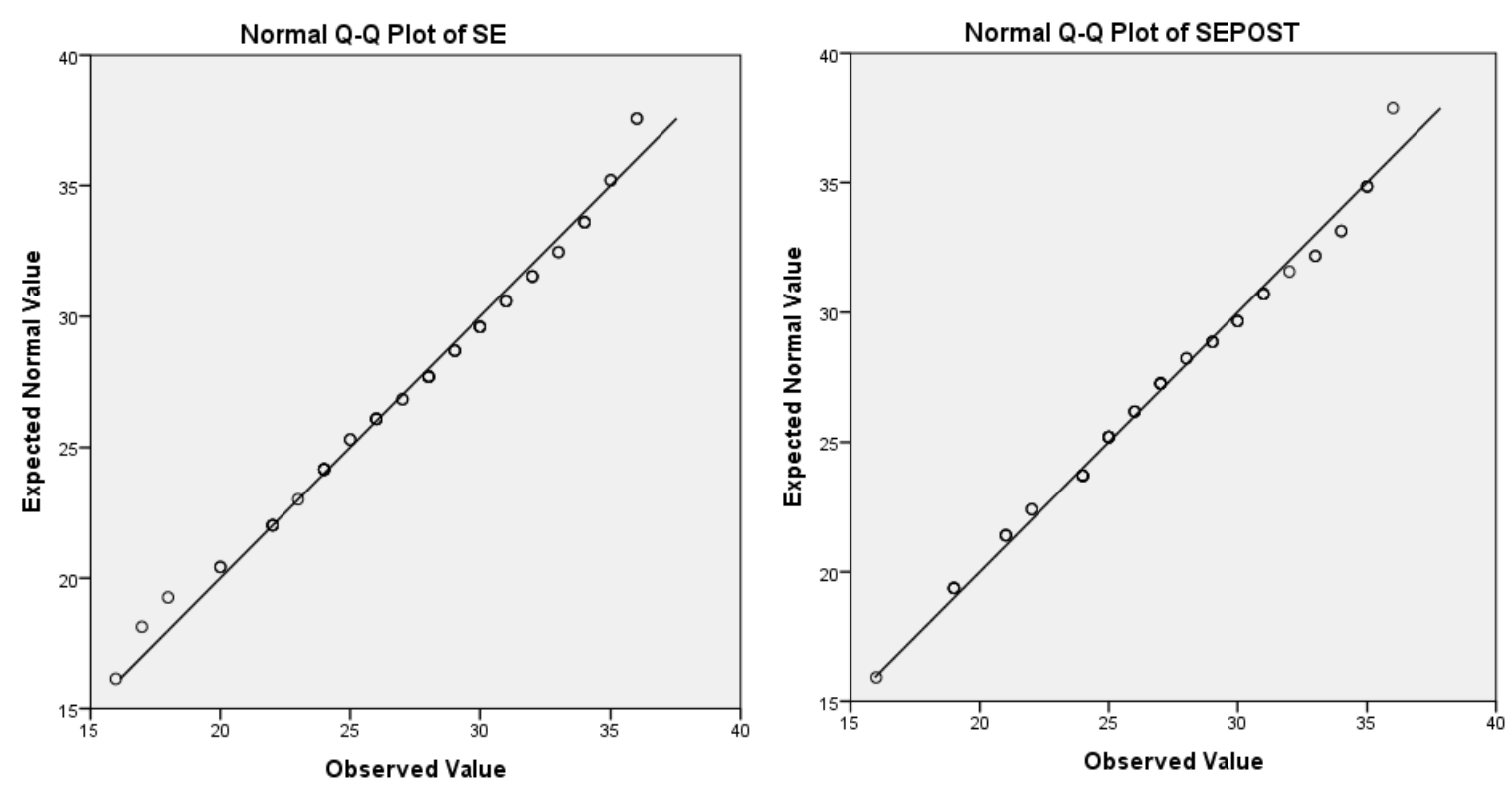

Figure 4. Normal Q-Q plots of the calculated pre- and post-test student engagement teacher efficacy scores.
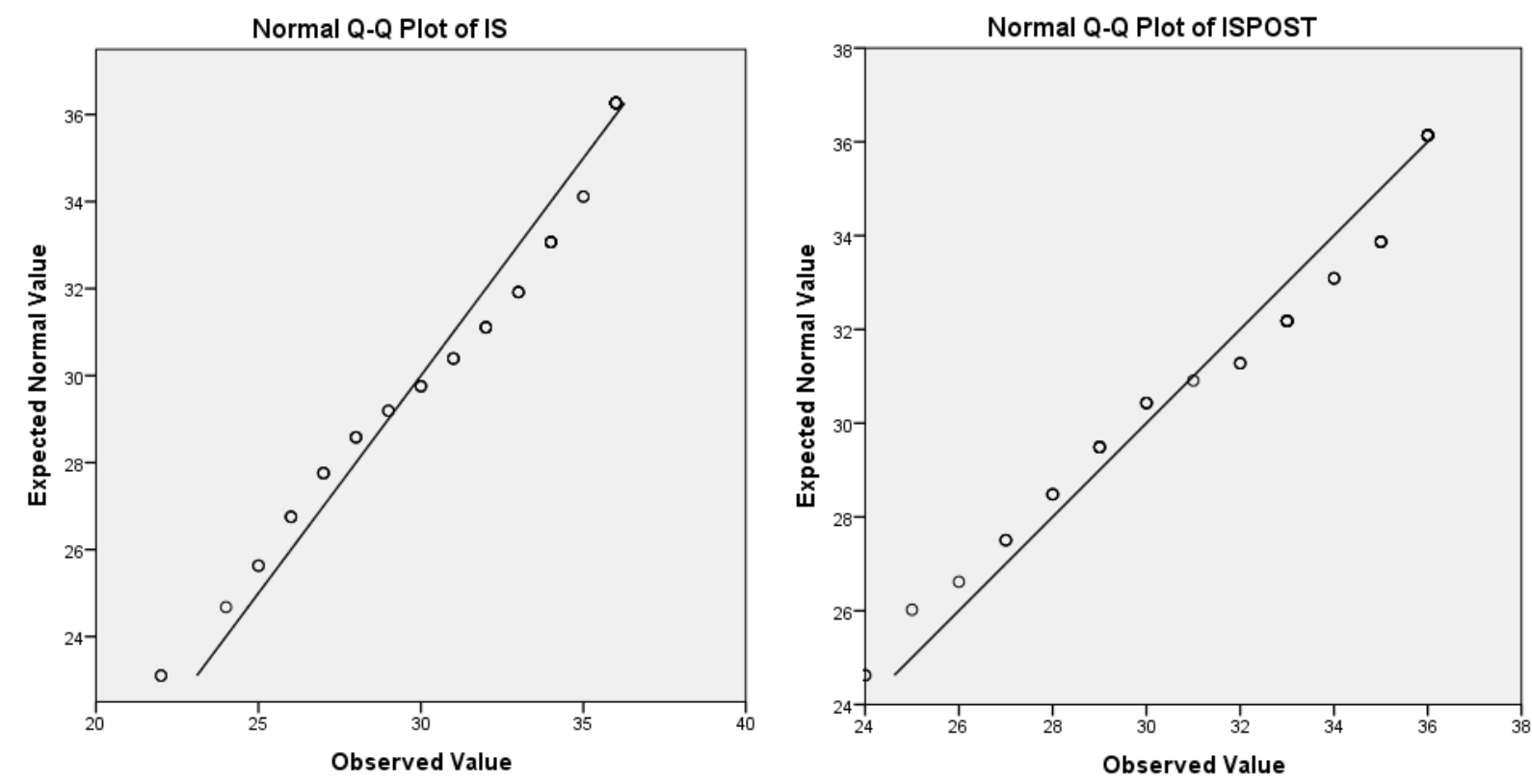

Figure 5. Normal Q-Q plots of the calculated pre- and post-test instructional strategies teacher efficacy scores. 


\section{Faculty Demographics}

The participants of this study were full-time faculty members at a large urban community college in southeastern United States. Pre- and post-surveys were completed by 55 faculty; approximately $53 \%$ were new (zero to four years teaching experience) and $47 \%$ experienced (four years or more teaching experience). Participant data from this study showed the largest proportion of respondents held a master's degree at nearly $64 \%$. This was followed by $20 \%$ with a doctorate, $9 \%$ bachelors, and $7 \%$ associates. It should be noted that the most common academic credential for community college faculty is a master's degree with a minimum of 18 graduate hours in the discipline (Southern Association of Colleges and Schools, 2003). However, "vocational and technical degree programs may require only a baccalaureate or associate degree for an instructor" (Finley \& Kinslow, 2016, p. 5). Results also indicated that the majority of participants have experience working in their field or area of expertise; roughly $56 \%$ with ten or more years, $31 \%$ with four to ten years, and $13 \%$ with less than four years. Though the majority of the faculty participants have at least a master's degree and possess the subject matter expertise in their discipline through "real world experience", this typically does not provide what is needed to fully understand the art of teaching and learning (a continuous journey to find the right combination of pedagogy, instructional methodologies, and more recently, computer-based instruction to help students learn). Faculty demographics can be further reviewed in Table 5 . 
Table 5

Frequencies of Teaching Experience, Education, and Field Experience

\begin{tabular}{cccccc}
\hline $\begin{array}{c}\text { Years of } \\
\text { Teaching } \\
\text { Experience }\end{array}$ & $n$ & $\begin{array}{c}\text { Highest } \\
\text { Educational } \\
\text { Credential }\end{array}$ & $n$ & \multicolumn{2}{c}{$\begin{array}{c}\text { Years of } \\
\text { Field } \\
\text { Experience }\end{array}$} \\
\hline $0-4$ & $29(52.7 \%)$ & Doctorate & $11(20.0 \%)$ & $0-4$ years & $7(12.7 \%)$ \\
$4+$ & $26(47.3 \%)$ & Masters & $35(63.6 \%)$ & $4-10$ years & $17(30.9 \%)$ \\
& & Bachelors & $5(9.1 \%)$ & 10 years or more & $31(56.4 \%)$ \\
& & Associates & $4(7.3 \%)$ & & \\
\hline
\end{tabular}

Note. $n=55$

\section{Item Level Analysis}

Descriptive statistics were used to determine the mean scores, standard deviations, and standard error of mean for each item as shown in Table 6. After differences were calculated preand post-test for each item, paired sample $t$-tests were used to determine if the differences in mean scores were statistically significant $(p<.05)$. Table 7 provides the mean differences for each item and the significance of these differences.

Item level analysis indicated no significant differences on efficacy scores, on average, from pre-test to post-test across survey items, with the exception of question 10, "To what extent can you provide an alternative explanation or example when students are confused?" This item had the highest average mean scores, as indicated in Table 6 , showing a significant improvement $\left(t_{(53)}=2.13, p=.04\right)$ from pre-test to post-test across all participants. The test item with the lowest average mean scores on the survey was question 11, "How much can you assist families in helping their students do well in school?" This item showed no significant improvement from pre- to post-test across participants. Furthermore, the standard deviation for this question was much higher than the other items, indicating a wider dispersion of scores from the mean. 
Table 6

Descriptive Statistics by Survey Item

\begin{tabular}{|c|c|c|c|c|c|c|}
\hline & $n$ & Min & $\operatorname{Max}$ & $M$ & $S D$ & SEM \\
\hline Q1Pre & 55 & 1 & 9 & 7.58 & 1.45 & .20 \\
\hline Q1Post & 55 & 3 & 9 & 7.51 & 1.18 & .16 \\
\hline Q2Pre & 54 & 3 & 9 & 6.94 & 1.59 & .22 \\
\hline Q2Post & 54 & 4 & 9 & 7.11 & 1.42 & .20 \\
\hline Q3Pre & 54 & 5 & 9 & 7.44 & 1.09 & .15 \\
\hline Q3Post & 55 & 5 & 9 & 7.46 & 1.13 & .15 \\
\hline Q4Pre & 54 & 4 & 9 & 7.39 & 1.41 & .19 \\
\hline Q4Post & 55 & 5 & 9 & 7.30 & 1.24 & .17 \\
\hline Q5Pre & 54 & 5 & 9 & 7.98 & 1.11 & .15 \\
\hline Q5Post & 55 & 5 & 9 & 7.96 & 1.08 & .15 \\
\hline Q6Pre & 55 & 2 & 9 & 7.67 & 1.28 & .17 \\
\hline Q6Post & 55 & 3 & 9 & 7.53 & 1.36 & .18 \\
\hline Q7Pre & 55 & 4 & 9 & 7.45 & 1.21 & .16 \\
\hline Q7Post & 55 & 3 & 9 & 7.36 & 1.40 & .19 \\
\hline Q8Pre & 54 & 5 & 9 & 7.87 & 1.15 & .16 \\
\hline Q8Post & 54 & 3 & 9 & 7.79 & 1.23 & .17 \\
\hline Q9Pre & 53 & 2 & 9 & 7.81 & 1.51 & .21 \\
\hline Q9Post & 55 & 4 & 9 & 7.91 & 1.32 & .18 \\
\hline Q10Pre & 54 & 6 & 9 & 8.07 & .93 & .13 \\
\hline Q10Post & 55 & 6 & 9 & 8.37 & .90 & .12 \\
\hline Q11Pre & 54 & 1 & 9 & 5.46 & 2.20 & .30 \\
\hline Q11Post & 55 & 1 & 9 & 5.28 & 2.35 & .32 \\
\hline Q12Pre & 54 & 3 & 9 & 7.52 & 1.48 & .20 \\
\hline Q12Post & 55 & 3 & 9 & 7.78 & 1.38 & .19 \\
\hline Valid N (listwise) & 46 & & & & & \\
\hline
\end{tabular}

Note: 9 Point Likert-type items rated on scale $1=$ Nothing to $9=$ A Great Deal 
Table 7

Paired Samples t-tests Results on Individual Survey Items (post-test to pre-test)

\begin{tabular}{|c|c|c|c|c|c|c|c|c|}
\hline & & & & $\begin{array}{l}95 \% \mathrm{Co} \\
\text { Interv } \\
\text { Diffe }\end{array}$ & $\begin{array}{l}\text { idence } \\
\text { of the } \\
\text { nce }\end{array}$ & & & \\
\hline & $\begin{array}{c}M \\
\text { Difference }\end{array}$ & $S D$ & SEM & Lower & Upper & $t$ & $d f$ & $\begin{array}{c}\text { Sig. } \\
\text { (2-tailed) }\end{array}$ \\
\hline Q1Post - Q1 & -.07 & .94 & .13 & -.33 & .18 & -.57 & 54 & .57 \\
\hline Q2Post - Q2 & .17 & 1.63 & .22 & -.28 & .62 & .76 & 52 & .45 \\
\hline Q3Post - Q3 & .02 & .98 & .13 & -.25 & .29 & .14 & 53 & .89 \\
\hline Q4Post - Q4 & -.09 & 1.40 & .19 & -.48 & .29 & -.48 & 53 & .63 \\
\hline Q5Post - Q5 & -.02 & 1.09 & .15 & -.32 & .28 & -.13 & 53 & .90 \\
\hline Q6Post - Q6 & -.15 & 1.03 & .14 & -.42 & .13 & -1.05 & 54 & .30 \\
\hline Q7Post - Q7 & -.09 & 1.13 & .15 & -.40 & .21 & -.60 & 54 & .55 \\
\hline Q8Post - Q8 & -.08 & 1.09 & .15 & -.38 & .23 & -.50 & 52 & .62 \\
\hline Q9Post - Q9 & .09 & 1.23 & .17 & -.24 & .43 & .56 & 52 & .58 \\
\hline Q10Post - Q10 & .30 & 1.02 & .14 & .02 & .58 & 2.13 & 53 & $* .04$ \\
\hline Q11Post - Q11 & -.19 & 2.67 & .36 & -.91 & .54 & -.51 & 53 & .61 \\
\hline Q12Post - Q12 & .26 & 1.25 & .17 & -.08 & .60 & 1.53 & 53 & .13 \\
\hline
\end{tabular}

* Significant at $p<.05$

\section{Efficacy Subscale Construct Analysis}

To address research questions 1-4 for this study, an analysis of each efficacy subscale (including overall efficacy) was conducted. As illustrated in Table 8, descriptive statistics were 
used to determine the mean scores, standard deviations, and standard error of mean for each efficacy subscale construct.

Table 8

Descriptive Statistics by Efficacy Subscale Construct

\begin{tabular}{lllll}
\hline & $n$ & $M$ & $S D$ & $S E M$ \\
\hline Overall Pre & 53 & 88.85 & 11.97 & 1.64 \\
Overall Post & 53 & 89.23 & 10.80 & 1.48 \\
CM Pre & 53 & 30.58 & 4.54 & .62 \\
CM Post & 53 & 30.19 & 4.28 & .59 \\
SE Pre & 53 & 27.28 & 5.00 & .69 \\
SE Post & 53 & 27.02 & 4.83 & .66 \\
IS Pre & 53 & 31.00 & 4.75 & .65 \\
IS Post & 53 & 32.02 & 3.59 & .49 \\
Valid N (listwise) & 53 & & & \\
\hline
\end{tabular}

Note: Classroom Management (CM), Student Engagement (SE), Instructional Strategies (IS)

Examining the differences in mean scores for overall and subscale efficacy constructs showed no significant impact from pre-test to post-test among the sample of community college faculty in this study. These results are further defined by research questions 1-4 followed by the full results of the paired samples $t$-tests in Table 9.

RQ1: What effect, if any, does a faculty development program explicitly modeled upon social learning theory have on community college overall teacher efficacy? Teacher efficacy was measured by a sum total of the 12 Likert-type items. For the faculty $(n=55)$ who participated in the professional development treatment, the overall mean pre-test score was 88.85 $(S D=11.97)$ and overall post-test score was $89.23(S D=10.80)$. The mean difference between post- and pre-test scores was $.38(S D=8.11)$. There was no significant difference in scores for overall teacher efficacy before and after participation in the program; $t_{(52)}=.34, p=.74$. 
RQ2: What effect, if any, does a faculty development program explicitly modeled upon social learning theory have on community college teacher efficacy specific to managing a classroom? Teacher efficacy was measured by a sum total of the unweighted means of items 1 , 6, 7, and 8. The classroom management efficacy mean pre-test score was $30.58(S D=4.54)$ and mean post-test score was $30.20(S D=4.28)$. The mean difference between post- and pre-test scores was -.38 $(S D=2.43)$. There was no significant difference in scores for teacher efficacy in managing a classroom before and after participation in the program; $t_{(52)}=-1.20, p=.24$.

RQ3: What effect, if any, does a faculty development program modeled upon social learning theory have on community college teacher efficacy specific to cultivating student engagement? Teacher efficacy was measured by a sum total of the unweighted means of items $2,3,4$, and 11. The student engagement efficacy mean pre-test score was $27.28(S D=5.00)$ and mean post-test score was $27.02(S D=4.83)$. The mean difference between post- and pre-test scores was -.26 $(S D=4.57)$. There was no significant difference in scores for teacher efficacy in cultivating student engagement before and after participation in the program; $t_{(52)}=-.42, p=.68$.

RQ4: What effect, if any, does a faculty development program modeled upon social learning theory have on community college teacher efficacy specific to implementing instructional strategies? Teacher efficacy was measured by a sum total of the unweighted means of items $5,9,10$, and 12 . The instructional strategies efficacy mean pre-test score was 31.00 (SD $=4.75)$ and mean post-test score was $32.02(S D=3.59)$. The mean difference between post- and pre-test scores was $1.02(S D=3.84)$. There was no significant difference in scores for teacher efficacy in implementing instructional strategies before and after participation in the program; $t_{(52)}=1.97, p=.06$. 
Table 9

Paired Samples t-tests Results on Efficacy Subscale Construct (post-test to pre-test)

\begin{tabular}{|c|c|c|c|c|c|c|c|c|}
\hline & & & & $\begin{array}{r}95 \% \mathrm{Co} \\
\text { Interva } \\
\text { Diffe }\end{array}$ & $\begin{array}{l}\text { fidence } \\
\text { of the } \\
\text { ence }\end{array}$ & & & \\
\hline & $\begin{array}{c}M \\
\text { Difference }\end{array}$ & $S D$ & SEM & Lower & Upper & $t$ & $d f$ & $\begin{array}{c}\text { Sig. } \\
\text { (2-tailed) }\end{array}$ \\
\hline Overall Post - Overall Pre & .38 & 8.11 & 1.11 & -1.86 & 2.61 & .34 & 52 & .74 \\
\hline CM Post - CM Pre & -.38 & 2.43 & .33 & -1.07 & .27 & -1.20 & 52 & .24 \\
\hline SE Post - SE Pre & -.26 & 4.57 & .63 & -1.52 & .99 & -.42 & 52 & .68 \\
\hline IS Post - IS Pre & 1.02 & 3.84 & .53 & -.02 & 2.10 & 1.97 & 52 & .06 \\
\hline
\end{tabular}

\section{Faculty Tenure Analysis}

To address research question 5, an analysis of group differences between new (teaching less than four years) and experienced faculty (teaching four years or more) on overall teacher efficacy scores was conducted. Table 10 details group statistics for overall pre- and post-scores. An independent samples $t$-test was used to compare the overall mean scores for each faculty group (new and experienced) to determine if there were any differences before and after participating in the faculty development treatment. The Levene's Test for Equality of Variances indicated that the variances were equal across both groups, pre- $(p=.91)$ and post-test $(p=.48)$. 
Table 10

Descriptive Statistics by Faculty Tenure

\begin{tabular}{lccccc}
\hline & Years Teaching & $n$ & $M$ & SD & SEM \\
\hline \multirow{2}{*}{ Overall Pre } & New $(0-4)$ & 29 & 87.66 & 12.29 & 2.28 \\
& Experienced (4+) & 26 & 89.58 & 11.52 & 2.26 \\
Overall Post & New $(0-4)$ & 29 & 85.90 & 11.29 & 2.10 \\
& Experienced (4+) & 24 & 93.25 & 8.82 & 1.80 \\
\hline
\end{tabular}

$n=55$

RQ5: What effect, if any, does years of teaching experience have on community college overall teacher efficacy after participating in a faculty development program modeled upon social learning theory? When examining if faculty tenure had an impact on overall teacher efficacy scores before participating in the faculty development treatment, it was concluded that there was no statistically significant difference between new $(n=29, M=87.66, S D=12.29)$ and experienced $(n=26, M=89.58, S D=11.52)$ faculty; $t_{(53)}=-.60, p=.55$. However, there was a significant difference in overall teacher efficacy scores after participating in the faculty development treatment between new $(n=29, M=85.90, S D=11.29)$ and experienced $(n=24$, $M=93.25, S D=8.82$ ) faculty; $t_{(51)}=-2.60, p=.01$. Table 11 provides a summary of these data. 
Table 11

Independent Samples t-tests for New and Experienced Faculty on Overall Efficacy Scores

$95 \%$ Confidence

Interval of the

Difference

\begin{tabular}{lccccccc}
\hline & $t$ & $d f$ & $\begin{array}{c}\text { Sig. } \\
(2 \text {-tailed })\end{array}$ & $\begin{array}{c}M \\
\text { Difference }\end{array}$ & SED & Lower & Upper \\
\hline Overall Pre & -.60 & 53 & .55 & -1.92 & 3.22 & -8.39 & 4.54 \\
Overall Post & -2.60 & 51 & $* .01$ & -7.35 & 2.83 & -13.03 & -1.67 \\
\hline
\end{tabular}

* Significant at $p<.05$

\section{Summary}

This chapter presented the results of the data analysis in determining if participation in a faculty development program modeled upon social learning theory had any impact on community college teacher efficacy beliefs. Descriptive statistics and paired sample $t$-tests were used to identify significant differences in pre-test and post-test mean scores in answering questions pertaining to the primary construct of overall teacher efficacy and efficacy for classroom management, student engagement, and instructional strategies. Teacher efficacy mean scores were higher in questions regarding implementing instructional strategies. Scores in questions aligned with cultivating student engagement were lowest, on average, than the subsequent constructs. No significant differences in teacher efficacy scores were noted across constructs, however, an item-level exploration provided additional information about how faculty rated their abilities to successfully perform specific teaching tasks.

The results of the quantitative analysis from this chapter illustrates that no significant shift in teacher efficacy scores (positive or negative) in managing a classroom, cultivating 
student engagement, or implementing instructional strategies can be attributed to participating in the faculty development treatment modeled upon social learning. However, there was a significant difference in overall teacher efficacy scores between new and experienced faculty after participating in the faculty development treatment. Chapter V presents an interpretation of these findings founded upon the literature review regarding community college faculty, faculty development, and teacher efficacy. This discussion is followed by recommendations for future research. 


\section{CHAPTER 5}

\section{CONCLUSIONS AND RECOMMENDATIONS}

The purpose of this study was to determine the effect, if any, of professional development modeled upon social learning theory on community college teacher efficacy. Five research questions were identified to observe the effects of a professional development experience grounded in social learning theory on the efficacy of new and experienced community college faculty. This chapter includes a summary of the study, providing the purpose, research questions, and methodology. This summary is followed by an interpretation of the results, including recommendations for the practice of faculty development in community colleges. Finally, the chapter concludes with recommendations for future research.

\section{Overview}

Community college faculty members represent a diverse group, with varying levels of educational attainment and proficiencies in classroom management, student engagement, and instructional strategies (Finley \& Kinslow, 2016). Grounded in Bandura's Social Learning Theory (1971), the associated concepts of self-efficacy (Bandura, 1977; 1994; 1997), perceived self-efficacy (Bandura, 1993), and teachers' self-efficacy (Gavora, 2010; Gibson \& Dembo, 1984; Ross, 1994; Tschannen-Moran \& Woolfolk Hoy, 2001), the intent of this study was to better understand if professional development modeled upon social learning theory would impact the efficacy beliefs and perspectives of community college faculty. "Teacher efficacy has proved to be powerfully related to many meaningful educational outcomes such as teachers' persistence, enthusiasm, commitment, and instructional behavior, as well as student outcomes such as achievement, motivation, and self-efficacy beliefs" (Tschannen-Moran \& Woolfolk Hoy, 2001, p. 783). Additionally, Karimi (2011) maintains, "Research intended to reveal the effects 
of interventions which have the potential to enhance teachers' beliefs about their ability is called for" (p. 59). Community college administrators and faculty developers may find the results of this study useful as they make decisions about program design and resource allocation.

Five research questions framed this study:

$\mathrm{RQ}_{1}$ : What effect, if any, does a faculty development program explicitly modeled upon social learning theory have on community college overall teacher efficacy?

$\mathrm{RQ}_{2}$ : What effect, if any, does a faculty development program explicitly modeled upon social learning theory have on community college teacher efficacy specific to managing a classroom?

$\mathrm{RQ}_{3}$ : What effect, if any, does a faculty development program modeled upon social learning theory have on community college teacher efficacy specific to cultivating student engagement?

$\mathrm{RQ}_{4}$ : What effect, if any, does a faculty development program modeled upon social learning theory have on community college teacher efficacy specific to implementing instructional strategies?

RQ5: What effect, if any, does years of teaching experience have on community college overall teacher efficacy after participating in a faculty development program modeled upon social learning theory?

This study employed a pre-experimental, one-group, pre-test-post-test research design to measure teacher efficacy change before and after participation in a faculty development treatment explicitly modeled on social learning theory. Using anonymized data sets, pre-existing data were analyzed by employing paired samples and independent samples $t$-tests to answer the research questions. The total sample of 55 participants included 29 new faculty and 26 
experienced faculty. The minimum sample size $(n=34)$, as indicated by a statistical power analysis (Hunt, n.d.) performed for sample size estimation, was exceeded, resulting in a statistically significant sample size for this study.

The faculty development treatment explicitly modeled upon social learning theory was developed and delivered by the Office of Professional Development at the case institution. The objective of the professional development was to improve and enhance faculty skill in managing a classroom, cultivating student engagement, and implementing instructional strategies. Four sessions emphasizing the components of social learning theory were facilitated over a six-week period. The sessions were built to allow for meaningful discussion, collaboration, and opportunities for building on the sources of teacher efficacy: mastery experiences, social modeling, social persuasion, and cognitive states (Bandura, 1977).

The use of a descriptive survey facilitated the collection of data. The Teachers' Sense of Efficacy Scale (TSES), developed by Tschannen-Moran and Woolfolk Hoy (2001), was used to gain a better understanding of the responsibilities that create difficulties for teachers in a wide range of school activities. Specifically, the TSES assesses a teacher's sense of efficacy with respect to the teaching tasks involved in student engagement, classroom management, and instructional practices. Faculty respondents rated their own efficacy for each of three areas of teaching (classroom management, student engagement, and instructional strategies), using a nine-point Likert-type scale ranging from 1 (nothing) to 9 (a great deal). Moreover, a demographic and personal characteristics questionnaire provided additional insight regarding each participant's teaching experience, formal education, and industry experience. 


\section{Conclusions}

Findings from the data presented in Chapter IV indicated no significant differences in scores for the primary construct of overall teacher efficacy $\left(t_{(52)}=.34, p=.74\right)$ before and after participating in a faculty development program modeled upon social learning theory. The same was true for the efficacy subscale constructs of classroom management $\left(t_{(52)}=-1.20, p=.24\right)$, student engagement $\left(t_{(52)}=-.42, p=.68\right)$, and instructional strategies $\left(t_{(52)}=1.97, p=.06\right)$. These findings are not consistent with previous research where faculty development programs have been proven to increase teacher efficacy over time (Callaway, 2016; Karimi, 2011; Rodgers et al., 2013; Rowbotham, 2015; Singh et al., 2013; Spence, 2016; Yoo, 2016).

An item-level analysis revealed no significant differences on efficacy scores from pre-test to post-test for all but one item. Survey questions aligned with research question 4 (SQ5, SQ9, SQ10, and SQ12) were specific to implementing instructional strategies. Question 10, “To what extent can you provide an alternative explanation or example when students are confused" had the highest average mean post-test scores and showed significant improvement pre- to post-test $\left(t_{(53)}=2.13, p=.04\right)$. This improvement in scores could have been attributed to the multiple opportunities for faculty to observe, practice, and implement instructional strategies during the professional development treatment.

Question 11, “How much can you assist families in helping their students do well in school" had the lowest average post-test scores. This question showed no significant improvement $\left(t_{(53)}=-.51, p=.61\right)$ over time and had a wider range of responses from the mean compared to the other items. Perhaps this dispersion of scores was attributed to the varying degree of familiarity faculty have with student support services offered by the college. These support systems for students can include academic, career, and financial counseling, or formal 
groups to help students through adversities. Faculty development programs can educate faculty on the services available and how to appropriately refer students without infringing on a student's privacy (U.S. Department of Education, 2011). This distribution of scores showed inconsistency on how faculty feel they can help students. However, with an understanding and awareness of the student resources and support services beyond the classroom, perhaps their efficacy may improve in this area.

Social learning theory is the process by which a person's social environment shapes how they behave and how they think. As reviewed in the literature presented in Chapter II, the adoption of cognitions and behaviors observed in others as a framework for faculty development is ideal because faculty prefer learning from each other (Angelo, 1994; Morris \& Usher, 2011). Peer influence is stronger because of the high level of trust that naturally occurs among faculty with whom they share direct and indirect ties. Weimer (1990) argues "Individual faculty members can model instructional attitudes and activities that will influence the classroom decisions of their colleagues" (p. 136).

Faculty development grounded in social learning theory has implications that should be considered as new programs are developed and implemented. Though a great deal of one's learning can happen through the process of observation, their learning may not necessarily be shown in their performance (Bandura, 1977). There is a distinction between "acquiring" and "performing" a behavior. A person will perform a behavior they have learned once there is motivation to do so. This is why reinforcement of appropriate behaviors and subsequently, punishment of inappropriate behaviors, should be a critical component of program activities. Faculty should also be exposed to a variety of techniques and tools for motivation in performing a behavior observed. This exposure to new techniques and instructional tools is an important 
step to breaking down traditional stereotypes in the old paradigm of community college teaching (Van Ast, 1999).

With limited time for formal professional development, community college faculty members tend to engage in informal development, commonly emulating the teaching styles from their own experiences which may be antiquated, inappropriate, or ineffective (Baran, Correia, \& Thompson, 2011; Covill, 2011; Garet et al., 2001; Gyurko, MacCormack, Bless, \& Jodl, 2016). Participation in faculty development plays a key role in faculty motivation, satisfaction with their careers, and can improve the academic experience for students (Rowbotham, 2015). With this in mind, the treatment implemented for this study was specifically designed to influence and increase teacher efficacy through exposure to best practices for teaching and opportunities for self-reflection, observation, and discussion. Yet, a quantitative analysis revealed no significant differences in teacher efficacy scores before and after participating. Conceivably taking a more holistic look at the specifics of this program and the themes that arose may help to provide a better understanding of these findings.

Theme 1: Culture influences commitment.

To effectively support community college faculty in their role as educator, professional development programs and activities are essential (Eddy, 2007). However, the degree to which faculty development programs are appreciated and valued by the faculty is specific to each institution's culture. As stated in Chapter II, faculty development means different things at different times, and there is no universal definition (Allen, 1988; Beach et al., 2016). A college culture frames and influences how faculty will embrace, participate, and evaluate professional development training. 
The case institution in this study has a centralized Professional Development office with full-time professional staff and support team members. This is not a common practice in community colleges (Cohen \& Brawer, 2003); faculty development is mostly facilitated on an as-needed basis by tenured faculty on release time or stipends. Workshops, a popular method of faculty development (Cohen \& Brawer, 1996), are frequently offered by the case institution's Office of Professional Development. These programs normally span one to three hours, at best, on various topics for improving professional skill and competency in teaching and learning.

Administrators support these professional learning opportunities for faculty and often encourage them to participate as appropriate. However, with competing priorities and heavy teaching loads that consume faculty time and energy, optional faculty development is often viewed as "nice-to-have" versus "must-have" in improving one's teaching and impact on student learning. Changing this perspective and culture of professional development will take time, but the benefit will be substantial in preparing faculty to teach the diverse community college student population. Gabay (2018) describes this phenomenon:

Professional development will no longer be seen as an afterthought but as an assortment of goodies among teaching responsibilities; it becomes part of the process. It is a steady stream of coaching, mentoring, collaboration, and open, honest discussions. (para. 8) As many community colleges report spending considerable amounts on faculty development, some faculty do not feel the necessity to personally participate (Murray, 2000). Faculty who do attend faculty development programs almost always involve a "minority of faculty members... many times the very faculty members (early adopters of new technology, strategies, and teaching practices) who least need to improve" (Allen, 1988, p. 94). These statements ring true in the culture of the case institution. Could it be that the faculty who 
volunteered to participate in the six-week program were the minority of early adopters and innovators making time for professional development? If this was the case, these are the very faculty who least needed to engage with the faculty development treatment.

The majority of faculty development programs offered at the case institution are "one and done" workshops. A six-week professional development program grounded in social learning theory was a unique opportunity; faculty may not have known what to expect from participating. Additionally, prior to the treatment, faculty were accustomed to taking a short survey after workshops that measured engagement with the hour's content. In contrast, the pre-test in the treatment entailed a deeper, more reflective guide to self-evaluation. This approach required more thoughtfulness and consideration for describing one's perception of skill in each survey item. Inexperience with this process and new way of thinking may have impacted how a faculty member rated their initial efficacy. On average, overall pre-test scores were high (8s and 9s on the Likert-type scale), leaving little, if any, room for efficacy scores to increase over time. Table 12 provides a summary of these data.

Table 12

Average Overall Efficacy Pre-test Scores

Average Overall Pre-test Score

$<2 \quad 2-4 \quad 5-7 \quad 8-9$

Number of Participants

0

2

20

31

Percentage of Population

$0 \%$

$4 \%$

$38 \%$

$58 \%$ 
Theme 2: Efficacy increases over time.

The faculty development treatment was implemented over a six-week period. This included three face-to-face sessions and one online session, totaling 10 contact hours of professional development. Faculty were also given the option to participate in a separate observation activity where they could observe faculty participants, or be observed themselves. Self-efficacy is developed over time based on the interaction between person, behavior, and outcome (Bandura, 1997). "Allowing faculty time and training needed to develop skills is critical in developing a higher sense of teaching efficacy" (Younger, 2011, p. 29).

Previous studies on teacher efficacy (Fishback et al., 2015; Fritz et al., 1995; Karimi, 2011; Rowbotham, 2015) provided more time for faculty to engage with the treatment (9 months to 2 years). When comparing this study to other studies, faculty participants had a much shorter time period to ingest new material, reflect, engage in meaningful discussions with peers, and most importantly, implement and practice new strategies in the classroom. However, this is not to say that professional development delivered in shorter durations is ineffective for impacting teacher efficacy. Some research has proven that teacher efficacy beliefs have improved after participating in professional development delivered in six weeks or less (Spence, 2016; Watson, 2006). Because there were limited differences in teacher efficacy mean scores over time observed in this study, the variable of time should be closely examined.

As the faculty participants in this study began to choose and execute modeled behaviors, it was time that allowed for consequences and feedback (including factors of the environment) to inform and influence teacher efficacy. The question is, was six-weeks, including 10 professional development contact hours, enough time for faculty to begin to gain a perception of the degree to which his or her actions could produce the desired outcome they were seeking? If faculty were 
allowed more time in this treatment to engage with the professional development and opportunities for implementing and evaluating new teaching strategies, there may have been significant impact on efficacy.

Similarly, implementing new techniques "disrupts the smoothness of the new practice" (Ross, 1994, p. 238). With time, as faculty begin to see new strategies are effective, they can "begin to enjoy increased student performance consistently" (Ross, 1994, p. 238). Hence, with positive results, their efficacy may eventually increase. A recommendation for future faculty development would allow faculty more time to "develop greater self-efficacy and a broader understanding of effective teaching" (Rowbotham, 2015, p. 22). This is especially true for new faculty with little to no experience of teaching. As efficacy is built on opportunity, new faculty need the time to gain from mastery experiences and verbal persuasion from others.

In addition to time, intentionally segregating the professional development by faculty tenure is advised. Data from this study revealed a significant difference in overall teacher efficacy scores after participating in the faculty development treatment between new and experienced faculty. New faculty overall efficacy scores decreased although experienced faculty scores increased over the six-week duration. Grouping faculty in explicit cohorts by experience level for professional development (such as first year, 2-3 years, 4-5 years and 5+ years) may have provided a different experience and result for impacting teacher efficacy (Tyndall, 2017).

Tschannen-Moran and Woolfolk Hoy (2001) describe mastery experiences that accrue over time as the strongest predictor of teacher efficacy beliefs. An experienced faculty member's initial efficacy may be different than new faculty because of the skills and attributes they have acquired through past teaching experiences. The overall efficacy scores for experienced faculty in this study increased over time. Perhaps their previous exposure to 
mastery experiences and self-awareness for influencing student learning impacted their initial rating on the TSES. After participating, their overall efficacy scores significantly increased, possibly due to the exposure to new vicarious experiences, social persuasion and affirmation from their peers, practicing and reflecting upon new teaching strategies, and confirmation that their existing teaching practices were effective.

Teacher efficacy for new faculty in this study decreased over time. Overall efficacy scores were higher at the start of the faculty development treatment; however, after a six-week exposure to the treatment activities, scores decreased. New faculty have had less opportunities to gain from mastery experiences and social persuasion. They are also less familiar with their somatic and emotional reactions to teaching and learning. This inexperience, coupled with the introduction of new instructional models through the professional development, including observations from peers, may have uncovered feelings of inadequacies or perceived weakness in tasks related to classroom management, student engagement, and instructional strategies, supporting the decline in overall teacher efficacy.

With the evolving role of community colleges (Baldwin, 2014; Barr \& Tagg, 1995; Morest, 2012; Nunley et al., 2011; Toner, 2016) and expectations of community college faculty, it is imperative that instructional leaders understand what constitutes as effective faculty development. Teachers with high self-efficacy expect to promote student learning (Heslin \& Klehe, 2006; Morris \& Usher, 2011). Therefore, leaders also need to discover which professional development opportunities actually result in improved efficacy and faculty behavioral changes to improve student success (Hamblin, 2015). Malnarich (2008) explains, "Good faculty development brings relevant scholarly work on teaching and learning to faculty attention ... No faculty development program will thrive that sets out to 'fix' faculty" (p. 1). 
Before faculty behavioral changes can be appropriately evaluated, it is only fair that they [faculty] are allowed the time they need and support they require to improve their knowledge, behaviors, and teaching skills (Lancaster et al., 2014).

Theme 3: Perception is impactful.

Bandura (1971) suggests that new behaviors can acquired through the observation of others via the concept of modeling. Faculty participants observed pre-identified faculty models exhibiting best practices and exemplary teaching regarding the establishment of classroom management, cultivation of student engagement, and implementation of instructional strategies. They also had the option to observe other faculty participants not formally identified as a model in the treatment. Although the concept of modeling was incorporated throughout the treatment based on the literature review of social learning theory, teacher efficacy scores did not reflect any significant change of personal beliefs for implementing the observed behaviors.

Social modeling is characterized by seeing success in people similar to one's self. The faculty models in the treatment (pre-identified and peer) may not have been influential to the participants. Ross (1994) suggests that the observation of new techniques may inadvertently bring inadequacies of one's own practice to the surface, which in turn, negatively impacts efficacy. This is especially true of new faculty whose efficacy is more impressionable than experienced faculty (Hoy \& Spero, 2005). Within observation, a new faculty member may realize how limited their experiences are in comparison to a more seasoned faculty member. This limited knowledge and narrowed sense of control over the learning environment will bring on feelings of inadequacy weakening efficacy beliefs.

Experienced faculty may also face this phenomenon through observation. This may occur when faculty discover the unspoken expectation for them to engage in deeper discussion, 
reflection, and sharing of innovative student-centered activities with other faculty peers. Should an experienced faculty member not feel they are sufficient in these areas through previous mastery experiences and social reinforcement, this perception of failure may lower their teacher efficacy beliefs.

A recommendation for faculty development that incorporates social learning as a foundation should consider the role of observation. If observation is not definitively considered, the exposure to a model's actions or skills might actually decrease an observer's efficacy. Tschannen-Moran et al. (1998) remark, "Watching others teach in skillful and adept ways especially observing admired, credible, and similar models — can affect the observer's personal teaching competence" (p. 230). Therefore, observation should be specific to a particular teaching skill or task, which distinguishes self-efficacy from other conceptions of self, such as self-concept, self-worth, and self-esteem (Tschannen-Moran, Woolfolk Hoy, \& Hoy, 1998). Support for faculty in their role as an observer, or as they are being observed, should include reinforcement of positive behaviors and environmental influences. Faculty development programs with observational components need to integrate activities that create a safe space for faculty to learn - a space where conceptions of self (personal feelings of inadequacy or incompetency) are readily addressed through transparency of expectations and support for the long-term development of teacher efficacy.

Social learning in faculty development allows faculty to share problems, ideas, viewpoints, and collaboration towards solutions (Clement, 2012; Guskey, 1995; Hunzickler, 2010). Because this professional development opportunity was grounded in social learning theory, participation was open to any full-time faculty member at the case institution, regardless of discipline or applied science area. Hamblin (2015) found that community college faculty 
valued learning experiences "that were reflective and applicable to the classroom" (p. 115), which is consistent with social learning. But although the activities in the treatment were social and interactive, no significant change in efficacy was proven. This could have been attributed to the diversity of disciplines represented or relevance of observing and emulating the teaching strategies modeled. Angelo (1994) argues,

Even those faculty who avidly participate in faculty development often have trouble understanding the relevance of teaching innovations or suggestions from disciplines other than their own. This difficulty often arises because general ideas about teaching aren't translated into discipline-specific terms and concepts that a teacher of a particular course can act upon. (p. 4)

Additionally, Lail (2005) found developmental activities related to a faculty's discipline is more effective than generic teaching tips. A question to consider is, would teacher efficacy have been impacted if the professional development incorporated opportunities for faculty to work with each other on discipline specific teaching tasks and challenges? Knowing that social persuasion builds efficacy, faculty collaboration among peers facing similar obstacles could provide more effective and specific feedback about how one teaches and their performance in the classroom.

\section{Recommendations for Future Research}

Few studies are available pertaining specifically to the community college faculty population. Even fewer studies have tested and evaluated specific models of faculty development at the community college level and the opportunities faced by teaching a diverse body of $21^{\text {st }}$ century learners:

This lack of knowledge about community college faculty results in reliance on portraits of community colleges and their faculties derived from a comparison with four-year 
college faculty, an inappropriate comparison that typically leaves community college faculty found wanting. (Twombly \& Townsend, 2008, p. 2)

Faculty want to be heard, engaged, and fully supported (Gabay, 2018). The culture of the institution can strengthen or dampen this spirit. Every community college is unique and culture should be the first consideration in how programs are marketed, designed, delivered, and evaluated. Given the array of responsibilities of community college faculty and their primary focus on student learning, administrators and those responsible for faculty development programming should commit to examining the teaching landscape before making decisions about what faculty need. This is especially true for those opportunities built for "transformative shifts in work culture... captured in ephemeral professional development methods that operate on low frequency" (Gabay, 2018, para. 1). Therefore, a continued evaluation of faculty development that improves community college teacher efficacy is warranted.

Research that intends to provide data on the effectiveness of specific faculty development models for community college faculty is necessary. It is important to note that this evaluation should be comprehensive and seek to appreciate results over and above participant satisfaction and engagement. Learning and behavior should also be assessed to determine if faculty have acquired the intended knowledge, skills, attitude, confidence and commitment, as well as applying what they have learned as a result of their participation in the program (Kirkpatrick Partners, 2018). Examining the experiences from faculty participants and reviewing data from products of student learning (Elliott \& Oliver, 2016) could offer additional insight for the evaluation of faculty learning and behavior change.

A qualitative approach for understanding faculty beliefs in their abilities to implement new strategies and manage their classrooms is needed. Qualitative insights would have been 
beneficial in formatively assessing the effectiveness of the program which speaks to a holistic program evaluation. Qualitative research challenges the questions we have about why or what, striving to get rich, in-depth data. An example of this kind of data are reflected in Appendix G, a sampling of qualitative feedback provided by the participants after the post-test survey. In this study, there is an assumption that we have developed an understanding about teacher efficacy through the sole use of a descriptive survey. However, mixed methods would build upon these results potentially enriching the evidence for discussion about teacher efficacy impact.

Considering the voice of faculty through qualitative methodologies would provide more breadth and depth for interpreting said change or impact of professional development programming on teacher efficacy and faculty learning.

As noted in Chapter II, community college faculty are a diverse group with varying degrees of life experience and perspective. It is recommended that they be grouped by discipline-based cohorts. Faculty appreciate and prefer learning from other faculty in their specific discipline (Angelo, 1994; Lail, 2005), as the teaching innovations and best practices for the instructional content is more closely aligned to their specific needs. The efficacy of these cohorts could be compared to disclose data that drives how faculty development programming could be made more explicit and meaningful to participants.

Investigating the effects of professional development on teacher efficacy that is differentiated for new and experienced community college faculty is highly recommended. As experience level brings dissimilar levels of self-awareness, self-efficacy, and self-perception, it seems plausible to consider experience (or inexperience) in faculty development programs. Program activities for each experience level should be relevant, specific, and centered on advancing skills in teaching and learning. A consideration for those who design and facilitate 
faculty development is to make decisions on how to appropriately group faculty, determine what constitutes a faculty member as "new", and agree on criteria for when faculty members shift from "new" to "experienced".

Segregating professional development by faculty tenure may also reduce faculty insecurities due to limited experience (for new faculty) or additional pressures to perform at a certain level (for experienced faculty). Engaging with peers who share similar professional objectives, challenges, or demands in the classroom, and associations with the institution would be more meaningful for community college faculty. This recommendation for differentiating program instruction ensures that faculty development is designed to support faculty in their specific place of tenure while promoting their confidence for influencing student learning.

\section{Summary}

The purpose of this study was to determine the effect, if any, of professional development modeled upon social learning theory on community college teacher efficacy. Community colleges, and consequently community college faculty, have experienced a shift in focus and accountability from simply access to access and student success (Baldwin, 2014; Barr \& Tagg, 1995; Morest, 2012; Nunley et al., 2011; Toner, 2016). Community college faculty start the first day of the semester facing some of the most challenging students in higher education, with little to no training or experience in how to teach (Hamblin, 2016). Moreover, with expectations for implementing quality teaching practices for student success, retention, and completion, it is even more critical for faculty to believe in their abilities to affect student learning in their role as educators.

Literature supports the positive links between teacher efficacy and teaching behaviors such as persistence at a task, risk-taking and the use of innovations (Ashton \& Webb, 1986; 
Guskey, 1988). A faculty member's views of self-efficacy are linked to their beliefs and attitudes about good teaching practices and impact the choices they make in the classroom (Fishback et al., 2015). Faculty development modeled upon social learning theory, which specifically speaks to a means of increasing teacher efficacy, may still be a viable option for increasing community college faculty skill and development, however further research in developing and evaluating this model is needed.

Faculty determine the best ways to teach content, facilitate learning, and encourage critical thinking of their students. "Faculty involvement in professional development activities has important effects on student academic achievement in terms of student perceptions of faculty effectiveness" (Elliott \& Oliver, 2016, p. 93). Therefore, the time faculty spend developing and improving their practice through professional development programming must be a valuable experience guided by specific goals and outcomes.

Community college faculty are being held accountable for effective course design and practices for student retention (Baker, Hope, \& Karandjeff, 2009; Smith, 2013; Van Ast, 1999), and should be sufficiently prepared for these responsibilities. Quality faculty development programming can provide support for increasing faculty skill and influencing teacher efficacy (Rodgers et al., 2013; Rowbotham, 2015; Singh et al., 2013). The findings of this study add to the literature for community college faculty development needs. The methodology to measure change on teacher efficacy pre- and post-participation helped "determine the promise of an intervention during its development phase" (Marsden \& Torgerson, 2012, p. 593) so that community college administrators, faculty developers, and stakeholders who make decisions about faculty development programming can use these findings as preliminary data for faculty support and engagement. 


\section{REFERENCES}

Allen, P. (1988). Faculty Development in Higher Education - A Literature Review. Digital Commons @ George Fox University. Retrieved from http://digitalcommons.georgefox. edu/soe_faculty/65

Allinder, R. M. (1994). The relationships between efficacy and the instructional practices of special education teachers and consultants. Teacher Education and Special Education, 17, 86-95. doi:10.1177/088840649401700203

American Association of Community Colleges. (2012). The Voluntary Framework of Accountability: Developing measures of community college effectiveness and outcomes. Retrieved from http://www.aacc.nche.edu/vfa

American Association of Community Colleges. (2017). Fast Facts From Our Fact Sheet. Aacc.nche.edu. Retrieved from http://www.aacc.nche.edu/AboutCC/Pages/ fastfactsfactsheet.aspx

Angelo, T. A., \& Cross, K. P. (1993). Classroom assessment techniques: A handbook for college teachers. San Francisco, CA: Jossey-Bass Publishers.

Angelo, T. (1994). From faculty development to academic development. AAHE Bulletin, 46(10), 3-7.

Armor, D., Conroy-Oseguera, P., Cox M., King, N., McDonnell, L., Pascal, A., .. Zellman, G. (1976). Analysis of the school preferred reading programs in selected Los Angeles minority schools. (REPORT NO. R-2007-LAUSD). Santa Monica, CA: Rand Corporation. 
Ashton, P., \& Webb, N. 1986. Making a difference: Teacher efficacy and student achievement. White Plains, NY: Longman.

Association for the Study of Higher Education (2007). ASHE Higher Education Report, 32(6), 19.

Ast, J. (1999). Community college faculty: Making the paradigm shift. Community College Journal of Research and Practice, 23(6), 559-579. doi:10.1080/106689299264585

Baker, E., Hope, L., Karandjeff, K. (2009). Contextualized Teaching \& Learning: A Faculty Primer. Center for Student Success, California Community Colleges.

Baldwin, C. (2014). Open access and the completion agenda: Are they compatible?. Perspectives. Retrieved from http://www.ccsse.org/docs/FSU_Perspectives _March2014.pdf

Bandura, A. (1971). Social Learning Theory. Morristown, NJ: General Learning Press.

Bandura, A. (1977). Social Learning Theory. Englewood Cliffs, NJ: Prentice Hall.

Bandura, A. (1982). Self-efficacy mechanism in human agency. American Psychologist, 37, 122147.

Bandura, A. (1993). Perceived self-efficacy in cognitive development and functioning. Educational Psychologist, 28(2), 117-148. doi:10.1207/s15326985ep2802_3

Bandura, A. (1994). Self-efficacy. In V. S. Ramachaudran (Ed.), Encyclopedia of human behavior (Vol. 4, 71-81). New York, NY: Academic Press.

Bandura, A. (1997). Self-efficacy: The exercise of control. New York, NY: Freeman.

Bandura, A. (2009). Cultivate self-efficacy for personal and organizational effectiveness. In E.A. Locke (Eds.), Handbook of principles of organization behavior ( $\left.2^{\text {nd }} \mathrm{ed}.\right)$. New York, NY: Wiley. 
Baran, E., Correia, A., \& Thompson, A. (2011). Transforming online teaching practice: Critical analysis of the literature on the roles and competencies of online teachers. Distance Education, 32(3), 421-439. doi:10.1080/01587919.2011.610293

Barr, R., \& Tagg, J. (1995). From teaching to learning — A new paradigm for undergraduate education. Change: The Magazine of Higher Learning, 27(6), 12-26.

Beach, A., Sorcinelli, M., Austin, A., \& Rivard, J. (2016). Faculty development in the age of evidence. Sterling, VA: Stylus Publishing.

Boggs, G. (2012). The evolution of the community college in America. Community College Journal, (February/March), 36-39.

Boice, R. (1984). The Relevance of Faculty Development for Teachers of Psychology. Teaching of Psychology, 11(1), 3-8. doi:10.1207/s15328023top1101_1

Boz, Y., \& Boz, N. (2010). The nature of the relationship between teaching concerns and sense of efficacy. European Journal of Teacher Education, 33(3), 279-291. doi:10.1080/ 02619768.2010 .490910

Brint, S., \& Karabel, J. (1989). Diverted dream: Community colleges and the promise of educational opportunity in America, 1900-1985. Oxford University Press.

Brown, G. (2012). Student disruption in a global college classroom: Multicultural issues as predisposing factors. ABNF Journal, 23(3), 63-69.

Brown, S. (2010). Likert scale examples for surveys. Retrieved from http://www.extension.iastate.edu/ag/staff/info/likertscaleexamples.pdf

Bruce, C., \& Ross, J. A. (2008). A model for increasing reform implementation and teacher efficacy: Teacher peer coaching in grade 3 and 6 mathematics. Canadian Journal of Education, 31, 346-370. 
Callaway, R. F. (2016). A correlational study of teacher efficacy and culturally responsive teaching techniques in a southeastern urban school district. Journal of Organizational \& Educational Leadership, 2(2), 1-27. Retrieved from https://files.eric.ed.gov/fulltext/ EJ1144813.pdfdocview/1853453541?accountid=12967

Chung Wei, R., Darling-Hammond, L., Andree, A., Richardson, N., \& Orphanos, S. (2009). Professional learning in the learning profession: A status report on teacher development in the U.S. and abroad. Dallas, TX: National Staff Development Council.

Clements, D. (2012). Community College Faculty Perceptions of Effective Professional Development, (Doctoral Dissertation). Retrieved from http://proxy.lib.odu.edu/ login?url=https://search-proquest-com.proxy.lib.odu.edu/docview/ 1022333875 accountid $=12967$

Cohen, J. (1988). Statistical power analysis for the behavioral sciences (2nd ed.). Hillsdale, NJ: Lawrence Earlbaum Associates.

Cohen, A., \& Brawer, F. (1996). The American community college (3rd ed.). San Francisco, CA: Jossey-Bass.

Cohen, A. M., Brawer, F. B., \& Kisker, C. B. (2014). The American Community College (6 ${ }^{\text {th }}$ ed.). San Francisco, CA: Jossey-Bass.

Community College Center of Student Engagement. (2012). Matter of Degrees: Promising Practices for Community College Student Success (A First Look). Austin, TX: The University of Texas at Austin, Community College Leadership Program.

Community College Center of Student Engagement. (2017). CCSSE - About CCSSE. Ccsse.org. Retrieved from http://www.ccsse.org/aboutccsse/aboutccsse.cfm 
Covill, Amy E. (2011). College students' perceptions of the traditional lecture method. College Student Journal, 45(1), 92-101.

Crawford, C., \& Jervis, A. (2011). Community colleges today. Contemporary Issues in Education Research, 4(8), 29-32. Retrieved from http://proxy.lib.odu.edu/login ?url=https://search-proquest.com.proxy.lib.odu.edu/docview/892678870?account $\mathrm{id}=12967$

Desimone, L., Porter, A., Garet, M., Yoon, K., \& Birman, B. (2002). Effects of professional development on teachers' instruction: Results from a three-year longitudinal study. Educational Evaluation and Policy Analysis, 24(2), 81-112.

Dicke, T., Wlling, J., Schmeck, A., \& Leutner, D. (2015). Reducing reality shock: The effects of classroom management skills training on beginning teachers. Teaching and Teacher Education, 48, 1-12. doi:10.1016/j.tate.2015.01.013

Duong, M., Nguyen, T., \& Nguyen, H. (2017). Demography factors and faculty members’ teacher efficacy in Vietnamese higher education. Journal of Studies in Education, (7)1, 17-31.

Eddy, P. (2007). Faculty development in rural community colleges. New Directions for Community Colleges, 137(7), 65-76. doi:10.1002/cc.271

Elliott, R., \& Oliver, D. (2016). Linking faculty development to community college student achievement: A mixed methods approach. Community College Journal of Research and Practice, 40(2), 85-99. doi:10.1080/10668926.2014.961590

Fain, P. (2014). Low Expectations, High Stakes. Inside Higher Ed. Retrieved from https://www.insidehighered.com/news/2014/04/07/part-time-professors-teach-mostcommunity-college-students-report-finds 
Falcon, L. (2015). Breaking down the barriers: First-generation college students and college success. Innovation Showcase, 10(6). Retrieved from https://www.league.org/innovationshowcase/breaking-down-barriers-first-generation-college-students-and-college-success

Faul, F., Erdfelder, E., Lang, A., \& Buchner, A. (2007). G*Power 3: A flexible statistical power analysis program for the social, behavioral, and biomedical sciences. Behavior Research Methods, 39, 175-191. Retrieved from http://www.gpower.hhu.de/fileadmin/redaktion/ Fakultaeten/Mathematisch-Naturwissenschaftliche_Fakultaet/Psychologie/AAP/ gpower/GPower3-BRM-Paper.pdf

Finley, D., \& Kinslow, S. (2016). Faculty talk about teaching at the community college. Oxford Handbooks Online. doi:10.1093/oxfordhb/9780199935291.013.47

Fishback, S., Leslie, B., Peck, L., \& Dietz, P. (2015). Community college faculty self-efficacy in student centered teaching. Adult Education Research Conference, (Paper 23). Retrieved from http://newprairiepress.org/cgi/viewcontent.cgi?article=1120\&context=aerc

Fives, H., \& Buehl, M. (2010). Examining the factor structure of the teachers' sense of efficacy scale. The Journal of Experimental Education, 78(1), 118-134. doi:10.1080/002209 70903224461

Ford, C. (2017). Understanding Q-Q Plots | University of Virginia Library Research Data Services + Sciences. Data.library.virginia.edu. Retrieved from http://data.library.virginia. edu/understanding-q-q-plots/

Fredricks, J. A., Blumenfeld, P. C., \& Paris, A. H. (2004). School engagement: Potential of the concept, state of the evidence. Review of Educational Research, 74(1), 59-109. 
Fritz, J., Miller-Heyl, J., Kreutzer, J., \& Macphee, D. (1995). Fostering personal teaching efficacy through staff development and classroom activities. The Journal of Educational Research, 88(4), 200-208. doi:10.1080/00220671.1995.9941301

Gabay, V. (2018). A Professional Development Makeover. Faculty Focus. Retrieved from https://www.facultyfocus.com/articles/faculty-development/professional-developmentmakeover/

Gaff, J., \& Simpson, R. (1994). Faculty development in the United States. Innovative Higher Education, 18(3), 167-176. doi:10.1007/bf01191111

Garet, M. S., Porter, A. C., Desimone, L., Birman, B. F., \& Yoon, K. S. (2001). What makes professional development effective? Results from a national sample of teachers. American Educational Research Journal, 38(4), 915-945. doi:10.3102/00028 312038004915

Gavora, P. (2010). Slovak pre-service teacher self-efficacy: Theoretical and research considerations. The New Educational Review. 21(2), 17-30.

Gibson, S., \& Dembo, M. (1984). Teacher efficacy: A construct validation. Journal of Educational Psychology, 76(4), 569-582. doi:10.1037/0022-0663.76.4.569

Ginder, S., Kelly-Reid, J., \& Mann, F. (2017). Enrollment and employees in postsecondary institutions, Fall 2015; and financial statistics and academic libraries, fiscal year 2015. Report of the National Center for Education Statistics. Retrieved from https://nces.ed.gov/pubs2017/2017024.pdf

Given, L. (2008). The Sage encyclopedia of qualitative research methods. Los Angeles, CA: Sage Publications. 
Gliem, J., \& Gliem, R. (2003). Calculating, interpreting, and reporting Cronbach's Alpha reliability coefficient for Likert-type scales. In Midwest Research to Practice Conference in Adult, Continuing, and Community Education. Columbus, OH: The Ohio State University. Retrieved from https://scholarworks.iupui.edu/bitstream/handle/1805 /344/gliem+\&+gliem.pdf?sequence=1

Guskey, T. R. (1988). Teacher efficacy, self-concept, and attitudes toward the implementation of instructional innovation. Teaching and Teacher Education, 4, 63-69. doi:10.1016/0742051X(88)90025-X

Guskey, T.R. (1995). Professional development in education: In search of the optimal mix. In T. Guskey and M. Huberman (Eds.), Professional Development in Education: New Paradigms and Practices (pp. 114-131) New York, NY: Teachers College Press.

Gyurko, J., MacCormack, P., Bless, M., \& Jodl, J. (2016). Why colleges and universities need to invest in quality teaching more than ever. Report of the Association of College and University Educators. Retrieved from http://acue.org/wp-content/uploads/2016/05/WhitePaper-201611114-Web.pdf

Hainline, L., Gaines, M., Feather, C., Padilla, E., \& Terry, E. (2010). Changing students, faculty, and institutions in the twenty-first century. $A A C \& U$ - Peer Review, 12(3). Retrieved from https://www.aacu.org/publications-research/periodicals/changing-students-faculty-andinstitutions-twenty-first-century

Hamblin, C. (2015). How Arizona community college teachers go about learning to teach, (Doctoral Dissertation). Utah State University. Retrieved from http://digitalcommons. usu.edu/cgi/viewcontent.cgi?article=5330\&context=etd 
Harkness, J. (2010). Adaptation of Survey Instruments. Projects.isr.umich.edu. Retrieved from http://projects.isr.umich.edu/csdi/adaptation.cfm

Henderson, K. (2016). The effect of higher education classroom management behavior strategies on learning, (Doctoral Dissertation). Walden University. Retrieved from http://scholarworks. waldenu.edu/cgi/viewcontent.cgi $?$ article=3317\&context=dissertations

Heslin, P., \& Klehe, U. (2006). Self-efficacy. Encyclopedia of Industrial/Organizational Psychology, 2, 705-708.

Horvitz, B., Beach, A., Anderson, M., \& Xia, J. (2014). Examination of faculty self-efficacy related to online teaching. Innovative Higher Education, 40(4), 305-316. doi:10.1007/s10755-014-9316-1

Hoy, W. K., \& Woolfolk, A. E. (1990). Socialization of student teachers. American Educational Research Journal, 27, 279-300.

Hoy, A.W., \& Spero, R. B. (2005). Changes in teacher efficacy during the early years of teaching: A comparison of four measures. Teaching and Teacher Education, 21, 343-356.

Hunt, A. A Researcher's Guide to Power Analysis. Utah State University. Retrieved from http://rgs.usu.edu/irb/wp-content/uploads/sites/12/2015/08/A_Researchers_Guide_ to_Power_Analysis_USU.pdf

Hunzickler, J. (2010). Characteristics of effective professional development: A checklist. Retrieved from Bradley University website: https:/files.eric.ed.gov/fulltext/ ED510366.pdf

Instructional Strategies - UCF Faculty Center for Teaching and Learning. (2017). Retrieved from http://www.fctl.ucf.edu/TeachingandLearningResources/InstructionalStrategies/ 
Illian, P. P. (2008). Creating passion in the classroom: Using professional development to create behavioral changes in adjunct college faculty, (Doctoral Dissertation). Retrieved from http://proxy.lib.odu.edu/login?url=https://search-proquest-com.proxy.lib.odu.edu/ docview/250764951 accountid=12967

Karimi, M. (2011). The effects of professional development initiatives on EFL teachers' degree of self-efficacy. Australian Journal of Teacher Education, 36(6), 50-62. doi:10.14221 /ajte.2011v36n6.6

Kauffman, D., Johnson, S. M., Kardos, S. M., Liu, E., \& Peske, H. G. (2002). Lost at Sea: New teachers' experiences with curriculum and assessment. Teachers College Record, 104(2), 273-300.

Kennedy, W., Eisner Hirsch, S., Rogers, W., Bruce, A., \& Lloyd, J. (2016). Supporting high school teachers' implementation of evidence-based classroom management practices. Teaching and Teacher Education, 63, 47-57. doi:1016/j.tate.2016.12.009

Kent State University (2018). LibGuides: SPSS Tutorials: Independent Samples $t$ Test. Retrieved from https://libguides.library.kent.edu/SPSS/IndependentTTest

Khan, A., Fleva, E., \& Qazi, T. (2015). Role of self-esteem and general self-efficacy in teachers' efficacy in primary schools. Psychology, 06(01), 117-125. doi:10.4236/psych.2015.61010

Khelifa, M. One-Way Repeated Measures Analysis of Variance. Zayed University Office of Research. Retrieved from https://zu.ac.ae/main/files/contents/research/training/OnewayRepeatedMeasureANOVA.pdf

Kirkpatrick Partners (2018). The New World Kirkpatrick Model. Retrieved from https://www.kirkpatrickpartners.com/Our-Philosophy/The-New-World-KirkpatrickModel 
Kratochwill, T., Deroos, R., \& Blair, S. (2017). Classroom Management. http://www.apa.org. Retrieved from http://www.apa.org/education/k12/classroom-mgmt.aspx

Lamorte, W., (2016). The Social Cognitive Theory. Retrieved from http://sphweb.bumc. bu.edu/otlt/MPH-Modules/SB/BehavioralChangeTheories/BehavioralChange Theories5.html

Lancaster, J., Stein, S., MacLean, L., Van Amburgh, J., \& Persky, A. (2014). Faculty development program models to advance teaching and learning within health science programs. American Journal of Pharmaceutical Education, 78(5), 99.

doi:10.5688/ajpe78599

Lane, D. (2007). Online Statistics Education: A Multimedia Course of Study. Retrieved from http://onlinestatbook.com/

Leslie, D., \& Gappa, J. (2002). Part-time faculty: Competent and committed. New Directions for Community Colleges, 2002(118), 59-68. doi:10.1002/cc.64

Levin, J., Kater, S., \& Wagoner, R. (2006). Community college faculty at work in the new economy. New York, NY: Palgrave MacMillan.

Little, J. (1993). Teachers' professional development in a climate of educational reform. Educational Evaluation and Policy Analysis, 15(2), 129-151. doi:10.2307/1164418

Malnarich, G. (2008). Increasing student engagement through faculty development: A Practice brief based on BEAMS project outcomes. Retrieved from http://www.ihep.org/sites/ default/files/uploads/docs/pubs/beams_increasing_student_engagement_faculty_develop ment.pdf 
Marsden, E., \& Torgerson, C. (2012). Single group, pre- and post-test research designs: Some methodological concerns. Oxford Review of Education, 38(5), 583-616. doi:10.1080/03054985.2012.731208

Matney, M. M. (2001). Institutional and departmental factors influencing faculty adoption of innovative teaching practices, (Doctoral Dissertation). Retrieved from https://deepblue.lib.umich.edu/handle/2027.42/128178

McClenney, K., \& Peterson, G. (2006). Effective educational practice: What we're learning from community college faculty. Community College Journal, 76(4), 24-27.

McClure, A. (2011). Developing Professionals. University Business Magazine. Retrieved from https://www.universitybusiness.com/article/developing-professionals

McCrum-Gardner, E. (2008). Which is the correct statistical test to use?. British Journal of Oral and Maxillofacial Surgery, 46(1), 38-41. doi:10.1016/j.bjoms.2007.09.002

McDonald, F. (1980). The problems of beginning teachers: A crisis in training (Vol. 1). Study of Induction Programs for Beginning Teachers. Princeton, NJ: Education Testing Service.

Millis, B. (1994). Faculty development in the 1990s: What it is and why we can't wait. Journal of Counseling \& Development, 72(5), 454-464. doi:10.1002/j.1556-6676.1994.tb00974.x

Modern Language Association. (2006). A community college teaching career. Modern Language Association. Retrieved from https://www.mla.org/About-Us/Governance/Committees/ Committee-Listings/Professional-Issues/Committee-on-Community-Colleges/ACommunity-College-Teaching-Career

Mojavezi, A., \& Tamiz, M. (2012). The impact of teacher self-efficacy on the students' motivation and achievement. Theory and Practice in Language Studies, 2(3). doi:10.4304/tpls.2.3.483-491 
Morest, V. S. (2012). Community college student success: From boardrooms to classrooms. Lanham, MD: Rowman \& Littlefield Publishers.

Morest, V. S. (2013). From access to opportunity: The evolving social roles of community colleges. The American Sociologist, 44(4), 319-328. doi:10.1007/s12108-013-9194-5

Morris, D., \& Usher, E. (2011). Developing teaching self-efficacy in research institutions: A study of award-winning professors. Contemporary Educational Psychology, 36(3), 232245. doi:10.1016/j.cedpsych.2010.10.005

Mundschenk, N., Miner, C., \& Nastally, B. (2011). Effective classroom management. Intervention in School and Clinic, 47(2), 98-103.

Murray, J. (2000). Faculty development in Texas two-year colleges. Community College Journal of Research and Practice, 24(4), 251-267. doi:10.1080/106689200264042

Murray, J. (2002). Faculty development in SACS-accredited community colleges. Community College Review, 29(4), 50-66.

New Jersey Council of County Colleges. (2013). Providing Access to Student Success. Trenton, NJ. Retrieved from http://www.njccc.org/wp-content/uploads/2013/06/8-panelbrochurev8.pdf

Northrup, D. (1997). The problem of the self-report in survey research. Institute for Social Research, 12(1).

Nugent, K., Bradshaw, M., \& Kito, N. (1999). Teacher self-efficacy in new nurse educators. Journal of Professional Nursing, 15(4). doi:10.1016/S8755-7223(99)80009-X

Nunley, C., Bers, T., \& Manning, T. (2011). Learning Outcomes Assessment in Community Colleges. New York, NY: National Institute for Learning Outcomes Assessment. 
Oliver, R. M., \& Reschly, D. J. (2010). Special education teacher preparation in classroom management: Implications for students with emotional and behavioral disorders. Behavioral Disorders, 35, 188-199

Parker, P. (2014). An examination of the impact of pedagogical preparation, teaching experience and future career plans on mathematics graduate teaching assistants' efficacy, (Doctoral Dissertation). Retrieved from https://scholarworks.gsu.edu/msit_diss/133/

Partnership for 21st Century Skills. (2009). Standards: A 21st century skills implementation guide. Report of the Partnership for 21st Century Skills. Retrieved from http://www.p21.org/storage/documents/p21-stateimp_standards.pdf

Perez, A., McShannon, J., \& Hynes, P. (2012). Community college faculty development program and student achievement. Community College Journal of Research and Practice, 36(5), 379-385. doi:10.1080/10668920902813469

Price, J., \& Cotten, S. (2006). Teaching, research, and service: Expectations of assistant professors. The American Sociologist, 37(1), 5-21. Retrieved from http://www.jstor.org/stable/27700445

Protheroe, N. (2008). Teacher Efficacy: What Is It and Does It Matter?. (Research Report: Principal). Alexandria, VA: National Association of Elementary School Principals. Retrieved from https://www.naesp.org/sites/default/files/resources/1/Pdfs/Teacher_ Efficacy_What_is_it_and_Does_it_Matter.pdf

Provasnik, S., \& Planty, M. (2008). Community colleges: Special supplement to the condition of education 2008. (Statistical analysis report). Washington, DC: U.S. Department of Education, National Center for Education Statistics. Retrieved from http://nces.ed.gov/pubs2008/2008033.pdf 
Pusser, B., \& Levin, J. (2009). Re-imagining community colleges in the $21^{\text {st }}$ century: A studentcentered approach to higher education. Center for American Progress Report. Retrieved from https://www.americanprogress.org/wp-content/uploads/issues/2009/12/pdf/ community_colleges_reimagined.pdf

Quick, D., \& Davies, T. (1999). Community college faculty development: Bringing technology into instruction. Community College Journal of Research and Practice, 23(7), 641-653. doi:10.1080/106689299264512

Raby, R., \& Valeau, E. (2014). Access and social capital: A profile of community college and global counterparts. Excellence in Higher Education, 5(1), 6-13. doi:10.5195/ ehe. 2014.126

Research Connections. (2016). Pre-Experimental Designs. Retrieved from https://www.researchconnections.org/childcare/datamethods/preexperimental.jsp

Richa. (2014). Instructional Strategies: Find the best approach to encourage independent learning. Retrieved from https://blog.udemy.com/instructional-strategies/

Rodgers, R., Christie, J., \& Wideman, M. (2013). The effects of a required faculty development program on novice faculty self-efficacy and teaching approach. Higher Education Quality Council of Ontario and Durham College. Retrieved from http://www.academia.edu/7594739/The_Effects_of_a_Required_Faculty_Development_ Program_on_Novice_Faculty_Self-Efficacy_and_Teaching_Approach_Prepared_by

Ross, J. (1994). Beliefs that make a difference: The origins and impacts of teacher efficacy. Paper presented at the Annual Meeting of the Canadian Association for Curriculum Studies, Calgary, Alberta: Canada. 
Rowbotham, M. A. (2015). The impact of faculty development on teacher self-efficacy, skills and perspectives. Illinois Education Research Council, 1, 2-28.

Saunders, M., Lewis, P., \& Thornhill, A. (2012). Research Methods for Business Students (6th ed.). New York, NY: Pearson Education Limited

Savas, A., Bozgeyik, Y., \& Eser, İ. (2014). A study on the relationship between teacher selfefficacy and burnout. European Journal of Educational Research, 3(4), 159-166. doi:10.12973/eu-jer.3.4.159

Shavaran, S., Rajaeepour, S., Kazemi, I., \& Zamani, B. (2012). Development and validation of faculty members' efficacy inventory in higher education. International Education Studies, 5(2), 175-184. doi:10.5539/ies.v5n2p175

Simonsen, B., Fairbanks, S., Briesch, A., Myers, D., \& Sugai, G. (2008). Evidence-based practices in classroom management: Considerations for research to practice. Education \& Treatment of Children, 31, 351-380.

Singh, T., De Grave, W., Ganjiwale, J., \& Supe, S. (2013). Impact of a fellowship program for faculty development on the self-efficacy beliefs of health professions teachers: A longitudinal study. Medical Teacher, 35, 359-364.

Smith, A. (2007). Professional development issues for community colleges. Peer Review, $A A C \& U$, 9(4). Retrieved from http://www.aacu.org/sites/default/files/ files/peerreview/PRFA07_Web.pdf

Smith, B. (2013). In the beginning: The role of community college faculty. Academic Senate. Retrieved from http://www.asccc.org/content/beginning-role-community-college-faculty0\# 
Sorcinelli, M. (2007). Faculty development: The challenge going forward. Peer Review, $A A C \& U, 9(4)$. Retrieved from http://www.aacu.org/sites/default/files/files/ peerreview/PRFA07_Web.pdf

Southern Association of Colleges and Schools. (2003). Faculty Credentials. Decatur, GA. Retrieved from http://www.sacscoc.org/pdf/081705/faculty\%20credentials.pdf

Spence, C. (2016). Impact of Professional Development in Response to Intervention on Secondary Teachers' Efficacy, (Doctoral Dissertation). Walden University. Retrieved from https://scholarworks.waldenu.edu/cgi/viewcontent.cgi?article=3279\& context $=$ dissertations

Sprouse, M., Ebbers, L., \& King, A. (2008). Hiring and developing quality community college faculty. Community College Journal of Research and Practice, 32(12), 985-998. doi:10.1080/10668920701831159

Statistics Solutions. (2017). Teachers' Sense of Efficacy Scale (TSES) - Statistics Solutions. Retrieved from http://www.statisticssolutions.com/teachers-sense-of-efficacy-scale-tses/ Steinert, Y. (2010). Faculty development: From workshops to communities of practice. Medical Teacher, 32(5), 425-428. doi:10.3109/01421591003677897

Stephens, N. M., Hamedani, M. G., \& Destin, M. (2014). Closing the social-class achievement gap: A difference-education intervention improves first-generation students' academic performance and all students' college transition. Psychological Science, 25(4), 943-953.

Swanger, D. (2016). Innovation in Higher Education: Can Colleges Really Change?. Report of Fulton-Montgomery Community College. Retrieved from https://www.fmcc.edu/about/ files/2016/06/Innovation-in-Higher-Education.pdf 
Tavakol, M., \& Dennick, R. (2011). Making sense of Cronbach's alpha. International Journal of Medical Education, 2, 53-55. doi:10.5116/ijme.4dfb.8dfd

The American Federation of Teachers in Higher Education. (2011). Student Success in Higher Education. Retrieved from https://www.aft.org/sites/default/files/studentsuccess0311.pdf

The Association for Educational Communications and Technology. (2001). What is descriptive research? Retrieved from https://www.aect.org/edtech/ed1/41/41-01.html

Toner, M. (2016). Community colleges: Creating the future. Innovative Practices. Retrieved from http://www.acenet.edu/the-presidency/columns-and-features/Pages/CommunityColleges-Creating-the-Future.aspx

Townsend, B., \& Twombly, S. (2007). Community college faculty: Overlooked and undervalued. ASHE Higher Education Report, 32(6).

Trainor, S. (2015). How Community Colleges Have Changed Education in the U.S. Time. Retrieved from http://time.com/4078143/community-college-history/

Tschannen-Moran, M., Woolfolk Hoy, A., \& Hoy, W. (1998). Teacher efficacy: Its meaning and measure. Review of Educational Research, 68(2). doi:10.2307/1170754

Tschannen-Moran, M., \& Woolfolk Hoy, A. (2001). Teacher efficacy: Capturing an elusive construct. Teaching and Teacher Education, 17, 783-805.

Twombly, S., \& Townsend, B. (2008). Community college faculty: What we know and need to know. Community College Review, 36(1), 5-24. doi:10.1177/0091552108319538

Tyndall, C. L. (2017). Called to teach: A mixed methods exploration of community college adjunct faculty's teaching self-efficacy, (Doctoral Dissertation). Retrieved from https://scholarscompass.vcu.edu/cgi/viewcontent.cgi?article=5797\&context=etd 
UCLA. (2017). Power analysis for paired sample t-test $\mid G^{*}$ Power Data Analysis Examples IDRE Stats. Retrieved from https://stats.idre.ucla.edu/other/gpower/power-analysis-forpaired-sample-t-test/

U.S. Department of Education (2011). FERPA for Students. Retrieved from https://www2.ed.gov/policy/gen/guid/fpco/ferpa/students.html

Van Ast, J., \& Mullen, E. (1999). The professional development of community college applied science and technology faculty. The Journal of Technology Studies, 25(1), 36-42.

Van Uden, J. M., Ritzen, H., \& Pieters, J. M. (2014). Engaging students: The role of teacher beliefs and interpersonal teacher behavior in fostering student engagement in vocational education. Teaching and Teacher Education, 37, 21-32.

Villegas, A., \& Lucas, T. (2002). Preparing culturally responsive teachers: Rethinking the curriculum. Journal of Teacher Education, 53, 20-32.

Watson, G. (2006). Technology professional development: Long-term effects on teacher selfefficacy. Journal of Technology and Teacher Education, 14(1), 151-165.

Wallin, D. L., \& Smith, C. L. (2005). Professional development needs of full time faculty in technical colleges. Community College Journal of Research and Practice, 29(2), 87-108.

Weisel, J. W. (2015). Examining self-efficacy in community college adjunct faculty, (Doctoral Dissertation). Retrieved from http://proxy.lib.odu.edu/login?url=http://search.proquest. com.proxy.lib.odu.edu/docview/1775525059?accountid=12967

Weimer, M. (1990). Improving college teaching: Strategies for developing instructional effectiveness. San Francisco, CA: Jossey-Bass.

Wergin, J. (1977). Evaluating faculty development programs. New Directions for Higher Education, 17(2), 57-76. 
Wyles, B. (1998). Adjunct faculty in the community college: Realities and challenges. New Directions for Higher Education, 1998(104), 89-93.

Younger, D. (2011). Factors Influencing Teaching Efficacy among Kansas Career and Technical Education Faculty, (Doctoral Dissertation). Retrieved from http://scholarworks.uark.edu/etd/172.

Zepke, N., \& Leach, L. (2010). Improving student engagement: Ten proposals for action. Active Learning in Higher Education, 11(3), 167-177.

Zonoubi, R., Rasekh, A., \& Tavakoli, M. (2017). EFL teacher self-efficacy development in professional learning communities. System, 66, 1-12. 


\section{APPENDIX A: TEACHERS' SENSE OF EFFICACY SCALE (TSES) SURVEY QUESTIONS}

A number of statements about organizations, people, and teaching are presented below. The purpose is to gather information regarding the actual attitudes of educators concerning these statements. There are no correct or incorrect answers. We are interested only in your frank opinions. Your responses will remain confidential.

INSTRUCTIONS: Please indicate your personal opinion about each statement by circling the appropriate response at the right of each statement.

KEY: A nine-point Likert-type scale - 1 (nothing) 3 (very little) 5 (some influence) 7 (quite a bit) 9 (a great deal)

1. How much can you do to control disruptive behavior in the classroom?

2. How much can you do to motivate students who show low interest in school work?

3. How much can you do to get students to believe they can do well in school work?

4. How much can you do to help your students' value learning?

5. To what extent can you craft good questions for your students?

6. How much can you do to get students to follow classroom rules?

7. How much can you do to calm a student who is disruptive or noisy?

8. How well can you establish a classroom management system with each group of students?

9. How much can you use a variety of assessment strategies?

10. To what extent can you provide an alternative explanation or example when students are confused?

11. How much can you assist families in helping their students do well in school?

12. How well can you implement alternative strategies in your classroom? 


\section{APPENDIX B: PERMISSION TO USE THE TEACHERS' SENSE OF EFFICACY SCALE}

COLLEGE OF

ANITA WOOLFOLK HOY, PH.D.

PROFESBOR

PSYCHOLOGICAL STUdies IN EDUCATION

Dear

You have my permission to use the Teachers' Sense of Efficacy Scale in your research. A copy the scoring instructions can be found at:

http://u.osu.edu/hoy.17/research/instruments/

Best wishes in your work,

Anita Woolfole thoy

Anita Woolfolk Hoy, Ph.D.

Professor Emeritus 


\section{APPENDIX C: DEMOGRAPHICS AND PERSONAL CHARACTERISTICS QUESTIONNAIRE}

1. Years teaching at the university level:

- 0-3

$4+$

2. Years teaching at the community college:

- 0-3

$4+$

3. Years teaching in secondary education:

- 0-3

4+

4. Highest degree or educational credential earned:

_ Associates Degree

_ Bachelor's Degree

_ Master's Degree

_ Masters +

__Doctorate

5. Years of experience working in your field

6. Learning or Training Preference

_ Workshop/Lecture

_ Peer to peer

_ Colloquia

_ Independent Study

_ Other 


\section{APPENDIX D: POST-TEST QUESTIONNAIRE}

1. What do you feel you gained from your participation in this session?

2. Is there any faculty member you would recommend in becoming a future model for a similar professional development session?

3. How was this session different from other faculty professional development opportunities you have participated/attended in the past?

4. Do you have any recommendations on how we can improve this session? Do you have any recommendations?

5. Did you attend any other professional development sessions outside of this six-week session? If so, how many hours (best estimate, whole numbers only)? 


\section{APPENDIX E: PROGRAM SYLLABUS}

\section{Description}

(PROGRAM NAME) is a 4-session course designed to facilitate interaction with your peers and learning about each other's teaching strategies and practices. This peer-to-peer faculty development opportunity meets 4 times over the next six weeks. Additionally, you can schedule observations of your peers and have them observe you at times that are good for your schedule. For participating, you will earn 10 PD credit hours and the opportunity to make long lasting networking relationships with other (INSTITUTION NAME) faculty. This is a great way to fasttrack your learning and improve your teaching! Snacks and water will be provided.

\section{Expectations}

Participants are expected to attend and actively participate in all 4 sessions and complete at least 2 observation experiences-- 1 observation of a peer and 1 of a peer observing you. Complete Observation Guides for each observation and bring those guides to the final session in order to receive credits.

\section{Schedule}

Tuesday, January 30, 2-4pm, (PD BUILDING LOCATION)

Session I: Introduction to course, demonstration of strategies, discussion, observation, and planning

January 31-February 12 (FACULTY LOCATION AND ONLINE)

Peer Observations: Schedule your pre-meeting, observation, and post-meeting to observe or be observed

Session II: Observation and application of new knowledge through exploration of possible solutions to common classroom scenarios.

Tuesday, February 13, 2-4pm, (PD BUILDING LOCATION)

Session III: Application of new knowledge through exploration of possible solutions to common classroom scenarios. Reflective practices.

February 14-March 5 (FACULTY LOCATION)

Peer Observations: Schedule your pre-meeting, observation, and post-meeting to observe or be observed (Must have at least 2 observation experiences completed by March 6th-- 1 of you observing a peer and 1 of a peer observing you)

Prepare a strategy to share with your peers at the March 6 class.

Tuesday, March 6, 2-4pm, (PD BUILDING LOCATION)

Session IV: Small group work to share strategies learned through experience. Bring your completed observations forms and your strategy. 


\section{APPENDIX F: HUMAN SUBJECTS APPROVAL}
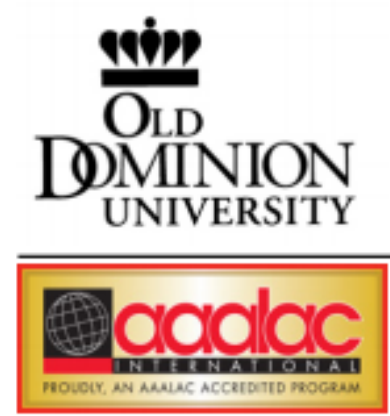

OFFICE OF THE VICE PRESIDENT FOR RESEARCH

Physical Address

4111 Monarch Way, Suite 203

Norfolk, Virginia 23508

Mailing Address

Office of Research

1 Old Dominion University

Norfolk, Virginia 23529

Phone(757) 683-3460

$\operatorname{Fax}(757) 683-5902$

DATE:

February 28,2018

TO:

FROM:

Michael Kosloski, PhD

PROJECT TITLE:

Old Dominion University Education Human Subjects Review Committee

[1200893-1] THE IMPACT OF PROFESSIONAL DEVELOPMENT

GROUNDED IN SOCIAL LEARNING ON COMMUNITY COLLEGE FACULTY EFFICACY

REFERENCE \#:

SUBMISSION TYPE: New Project

ACTION:

DETERMINATION OF EXEMPT STATUS

DECISION DATE:

February 28, 2018

REVIEW CATEGORY: Exemption category \# 6.4

Thank you for your submission of New Project materials for this project. The Old Dominion University Education Human Subjects Review Committee has determined this project is EXEMPT FROM IRB REVIEW according to federal regulations.

We will retain a copy of this correspondence within our records.

If you have any questions, please contact Jill Stefaniak at (757) 683-6696 or jstefani@odu.edu. Please include your project title and reference number in all correspondence with this committee.

This letter has been electronically signed in accordance with all applicable regulations, and a copy is retained within Old Dominion University Education Human Subjects Review Committee's records. 


\section{APPENDIX G: SAMPLING OF QUALITATIVE PARTICIPANT FEEDBACK}

What do you feel you gained from your participation in this session?

- Reassurance

- Good activities to engage students.

- Good ideas

- How to use a variety of activities to keep students actively engaged.

- I gained some new ideas on how to engage students in class.

- Ways to better improve teaching strategies.

- I do not feel I gained anything from my participation in this session.

- additional classroom engagement exercises to improve learning

- Several new engagement techniques. Ideas about how to handle difficult classroom situations.

- Some new assessment and motivation activities.

- How to help students learn

- I gained a lot

- Other methods of engaging student activities.

- Learned excellent ideas like verbal judo to use in the classroom

- New ideas about techniques to engage my students.

- Understanding different challenges in the classroom and how to respond.

- Learned how to use different types of content and activities to get students engaged and keep them that way

- How to engage students and motivate them to do well

- New ideas for effective teaching and classroom management.

- Four Corners as an active learning strategy for classroom instruction. A variety of methods on how to engage students in learning.

- I learned how other instructors handle common issues in their classroom.

- Sharing strategies that work.

- I enjoyed seeing friends.

- It was very insightful to gain firsthand accounts from faculty on classroom management.

- Making connections with people you may not know that well or someone you want to learn more from.

- Being able to see other examples of blackboard shells was very helpful. I learned a lot of things I plan to implement or use. Thank you!

- Interactions and ideas

- I have enjoyed spending time with other faculty and sharing ideas. It is great to be able to take time to do this. Observing was a great idea and I feel like I have built relationships and also gained new strategies for my classroom.

How was this session different from other (name of institution) faculty development opportunities you have participated/attended in the past?

- Active learning

- More engaging. 
- I do not feel like I have benefited from any faculty development opportunities I have attended.

- It involve our participation and discussion between all faculty so that we can learn from everyone and not only the PD instructor

- Was similar in format but had a different focus

- We got to do a lot of different techniques during the class.

- I like the small group size I have only had one other employer who had an extensive employee orientation. I think it needs to be adopted in all professions.

- Very interactive and informative

- It was fun and informative!

- It was engaging and informative yet fun for all participants.

- Similar but did use some practical examples

- Meet other people and learn other strategies from other teachers

- More active participation and discussion.

- They never let me down with constructive comments and examples as well as support. This one really helped me with understanding the schools policies and support that I have and taught me different strategies that I could use in the classroom. However, when I have shared with my department the things that I have learned, I was told that I couldn't implement any of the strategies. But I do appreciate learning them all, and will continue to try to get my department to embrace them in the future.

- This focused on sharing alternative teaching and classroom management techniques. It was more interactive.

- It is mostly social instead of informational.

- More interaction, creativity, and fun!

- Not a single PowerPoint presentation! :)

- good sharing

- The ability to just sit and talk with faculty.

- The observation piece was a great addition.

- More depth, deeper challenges

- It was much more involved, especially with homework between sessions.

- I got meet faculty from other areas, who may have different teaching styles.

- Very interactive everyone was very participatory and willing to share their experiences rather than sitting and listening

- Collaboration with faculty outside my discipline I had an opportunity to really talk with other faculty members and get their feedback on issues I deal with. This session was all inclusive and community oriented. I really enjoyed the F4F sessions.

- I like that it was more open and focused on what we needed, less structured in terms of just sitting in class.

- Actually observing and then meeting with faculty and the last session of sharing ideas. Great format. The session was different because we were able to discuss more instead of being inactive during a traditional PD session.

- I find that when we are able to discuss what we are doing and learn from others, we gain more insight.

- Very interactive (exchange of information) 
- It seemed more involved than most PD sessions, especially in that we have been able to learn closely with other faculty.

- There was more informal discussion among peers.

- This is helpful as colleagues open up and discuss their experiences. Very interactive. I really enjoy the "hybrid" manner is which it was delivered. By this I mean that not all the learning took place in the room.

- This was more collaborative not just informative

- More opportunity to speak informally to my peers.

- More personalized - let us talk to/observe who we wanted, as opposed to listening to a "talking head" presenter. 


\title{
VITA
}

\section{Shanika Shantell Strickland-Davis}

\author{
Darden College of Education \\ Department of STEM and Professional Studies \\ Old Dominion University \\ Norfolk, VA 23529 \\ Email: shantell.stricklanddavis@gmail.com
}

\section{PROFESSIONAL OVERVIEW}

Shantell Strickland-Davis is an instructional design leader, educator, and project manager with strengths and skills in curriculum design and development, learning facilitation, quality assurance, visual literacy, and process design. She is a confident self-starter offering effective interpersonal and communication skills with the ability to foster long-term relationships. Additional areas of value and core competencies include:

- Strong knowledge of adult education theory, concepts, techniques, and methodologies,

- Solid experience with designing, developing, and facilitating learning opportunities (online and traditional seated) that promote a high level of student engagement, optimizing student understanding and focus,

- Comprehensive knowledge of various instructional design models (Agile, ADDIE, SAM, Dick and Cary, Gagne) ensuring successful application to scope of design and project management,

- Application of measurement/evaluation of learning, and assessment techniques that meet student learning outcomes, ensuring an effective learning process.

\section{EDUCATION}

Ph.D. in Education - Occupational and Technical Studies, Old Dominion University (2018)

Master of Arts - Educational Media, Instructional Technology (Instructional Design Specialist), Appalachian State University (2011)

Bachelor of Arts - Sociology, University of North Carolina at Charlotte (2003)

\section{PROFESSIONAL EXPERIENCE}

Director, Learning Innovation \& Instructional Design, Central Piedmont Community College Director, Employee Online Learning \& Development, Central Piedmont Community College Instructional Developer II, Central Piedmont Community College Adjunct Faculty, Central Piedmont Community College 